\title{
ADUBAÇÃO VERDE: EFEITOS SUPRESSIV́OS SOBRE A INFESTAÇÃO DE PLANTAS DANINHAS E SELETIVIDADE DE HERBICIDAS
}

FRANCISCO JOSÉ SEVERINO

Engenheiro Agrônomo

Orientador: Prof. Dr. PEDRO JACOB CHRISTOFFOLETI

Dissertação apresentada à Escola Superior de Agricultura "Luiz de Queiroz", Universidade de São Paulo, para obtenção do título de Mestre em Agronomia, Área de Concentração: Fitotecnia.

PIRACICABA

Estado de São Paulo - Brasil

Dezembro - 2000 


\begin{tabular}{|c|c|c|}
\hline Página & Onde se lê: & Leia-se: \\
\hline 2 & ... plantas daninha ... & $\ldots$ plantas daninhas ... \\
\hline 14 & ... a unidade ... & ... à unidade ... \\
\hline 22 & ... economica ... & ... econômica... \\
\hline 24 & ... (Persea Americana Mill.) ... & ... (Persea americana Mill.) ... \\
\hline 26 & ... (Piamonte, 1996; )... & ... (Piamonte, 1996) ... \\
\hline 29 & ... Tabela 3.2. Argilosa ... & $\ldots$ Franco-argilosa ... \\
\hline 37 & ... Tabela 3.6 .22 .4 cA ... & $\ldots 22,4$ cA $\ldots$ \\
\hline 38 & ... guandu anão e destas... & ... guandu anão e desta... \\
\hline 41 & ... Tabela 3.8. 354,1 Ab... & $\ldots 354,1 \mathrm{aB} \ldots$ \\
\hline 46 & ... amostragens de solo feita... & $\ldots$ amostragens de solo feitas... \\
\hline 49 & ... prolongadas nas aéreas... & ... prolongadas nas áreas... \\
\hline 52 & $\ldots$ as quais mostraram... & ... as quais não mostraram... \\
\hline 53 & $\begin{array}{c}\text {... seguida por Cajanus cajan } \\
\text { e Arachis pintoi ... }\end{array}$ & $\begin{array}{c}\text {... seguida por Arachis pintoi } \\
\text { e Cajanus cajan ... }\end{array}$ \\
\hline 54 & Analisando a Tabela 4.2, em ... & Analisando a Tabela $4.1, \mathrm{em} . .$. \\
\hline 60 & ... trifluralin, oxiflurfen e ... & $\ldots$ trifluralin, oxifluorfen $\mathrm{e} .$. \\
\hline 67 & ... resultados de fototoxicidade $\ldots$ & ... resultados de fitotoxicidade... \\
\hline 68 & $\begin{array}{c}\text { Tabela 5.4 } 30 \text { DAA, } 45 \text { DAA } \\
\text { 60DAA e } 75 \text { DAA }\end{array}$ & $\begin{array}{c}07 \mathrm{DAA}, 14 \mathrm{DAA}, 21 \mathrm{DAA} \\
\text { e } 28 \mathrm{DAA}\end{array}$ \\
\hline 83 & $\ldots($ Crotalária juncea $) \ldots$ & $\ldots($ Crotalaria juncea $) \ldots$ \\
\hline 83 & $\ldots$ teste de Tukey para $0,05 \% \ldots$ & $\ldots$ teste de Tukey a $5 \% \ldots$ \\
\hline 97 & $\ldots$ a quantidade $8 x, \ldots$ & $\ldots$ a quantidade $8 x \ldots$ \\
\hline
\end{tabular}


Dados Internacionais de Catalogação na Publicação (CIP)

DIVISÃO DE BIBLIOTECA E DOCUMENTAÇĀO - Campus "Luiz de Queiroz"/USP

\section{Severino, Francisco José}

Adubação verde : efeitos supressivos sobre a infestação de plantas daninhas $e$ seletividade de herbicidas / Francisco José Severino. - Piracicaba, 2000.

$120 \mathrm{p}$.

Dissertação (mestrado) - - Escola Superior de Agricultura Luiz de Queiroz, 2000.

Bibliografia.

1. Adubação verde 2. Adubo verde 3. Dinâmica populacional 4. Herbicida 5. Manejo integrado 6. Planta daninha 7. Rotação de cultura 8. Seletividade I. Titulo

CDD 631.874 
Aos meus pais, Zoé e Enide, pelo amor, respeito e compreensão que sempre recebi e, principalmente, pelos valores por eles transmitidos durante a minha vida;

A minha esposa Sandra e aos meus filhos Gabriel e Lucas, pelo amor, paciência, compreensão e incentivo demonstrados durante todo o periodo de desenvolvimento do Programa de Mestrado;

Ao meu orientador, Prof. Dr. Pedro Jacob Christoffoleti, pela oportunidade, experiência, incentivo, amizade e por acreditar na minha proposta de trabalho;

Ao meu primo Eduardo "In memorian", que partiu precocemente e que certamente iria se orgulhar em ver esse trabalho realizado.

Dedico

Às futuras geraçōes, desejando que respeitem os interesses de todos $e$ protejam a integridade do sistema global de ecologia e desenvolvimento.

Ofereço 


\section{AGRADECIMENTOS}

À Jesus Cristo, por ser uma presença sempre constante em minha vida;

Ao Prof. Dr. Pedro Jacob Christoffoleti pela, dedicação e paciência na orientação e, principalmente, pela amizade construída durante o Programa de Mestrado;

À Coordenação do Curso de Pós-graduação em Fitotecnia, pela oportunidade de realização do Curso;

Ao Prof. Dr. Ricardo Victoria Filho pelo apoio e amizade constantes;

Aos Professores Doutores Álvaro Pires da Silva (ESALQ/USP) e Rubismar Stolf (UFSCAR), pelo incentivo, apoio e amizade;

Aos professores do Departamento de Produção Vegetal da ESALQ/USP, pelos conhecimentos transmitidos e dedicação aos alunos;

Aos funcionários do laboratório de plantas daninhas, Luiz Ferrari, Aparecido Mendes e Ony Rodrigues de Campos, pelo auxilio e amizade durante o desenvolvimento dos trabalhos;

Às secretárias do Departamento de Produção Vegetal da ESALQ/USP, Ivete, Beth, Célia, Sílvia e Dona Helena, pela amizade e dedicação; 
A todos os funcionários do Departamento de Produção Vegetal da ESALQ/USP pela colaboração e amizade;

Aos colegas do Curso de Pós-graduação na área de concentração de Fitotecnia e de outros Cursos da ESALQ;

À CAPES pela concessão da bolsa de Pós-Graduação;

E, a todas as pessoas que contribuiram direta ou indiretamente para a realização desse trabalho.

"Ninguém presta à sua geração maior serviço do que aquele que, seja pela sua arte, seja pela sua existência, lhe proporciona a dádiva de uma certeza" (James Joyce) 


\section{SUMÁRIO}

LISTA DE FIGURAS ...............................................................

LISTA DE TABELAS............................................................... vii

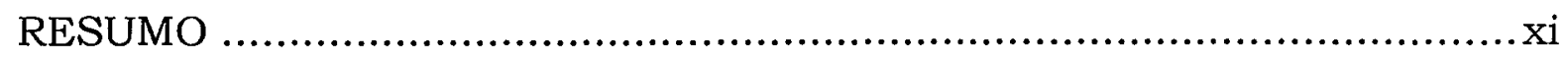

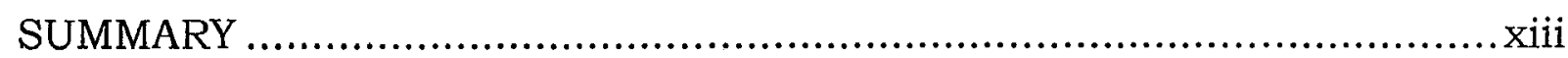

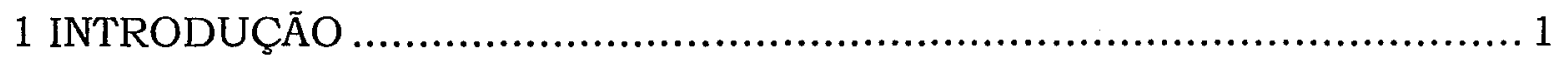

2 REVISĀO DE LITERATURA ..................................................... 4

2.1 Rotaçāo de culturas ........................................................... 4

2.2 Efeitos da rotação de culturas sobre a população de plantas daninhas ............................................................................ 6

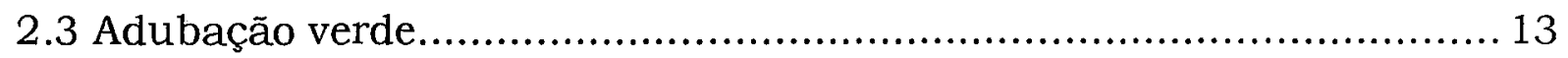

2.4 Adubo verde perene........................................................... 17

2.4.1 Controle de plantas daninhas pelo adubo verde perene ................ 17

2.4.2 Controle do crescimento dos adubos verdes perenes.................... 19

2.4.3 Amendoim forrageiro (Arachis pintoi) como adubo verde perene, sua origem e classificação botânica.......................................20

3 INTERAÇÕES COMPETITIVAS ENTRE ADUBAÇÃO VERDE E

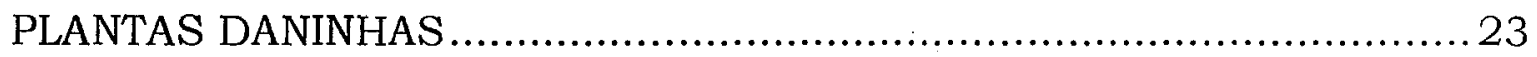

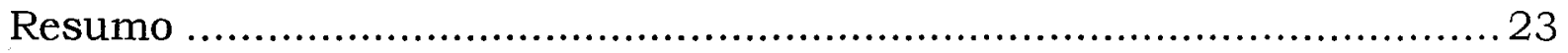

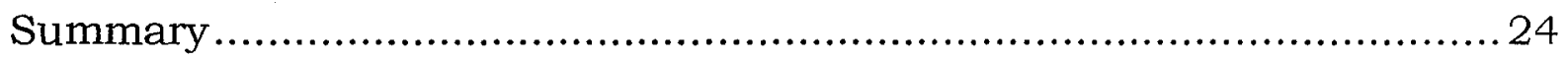

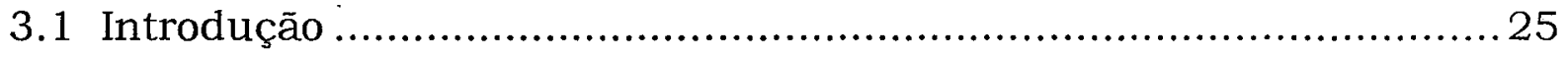

3.2 Material e Métodos.............................................................. 28

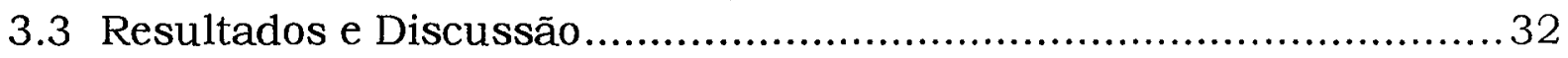

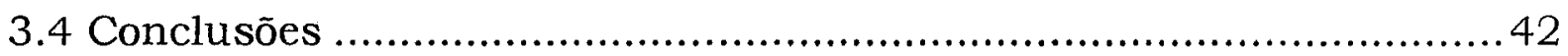

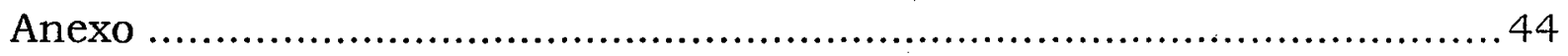

4 EFEITOS DE ADUBOS VERDES NO RECRUTAMENTO DO BANCO DE SEMENTES DE PLANTAS DANINHAS .......................................... 46 


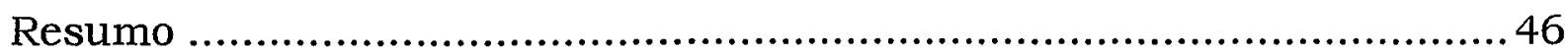

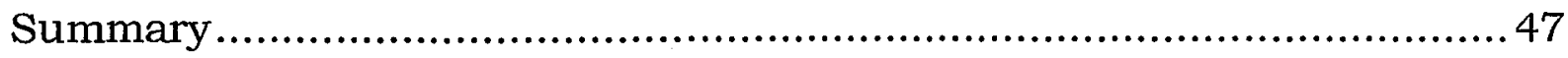

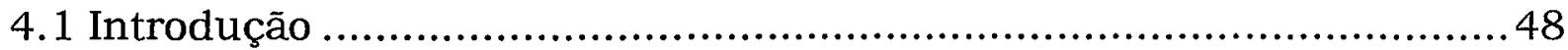

4.2 Material e Métodos .......................................................... 50

4.3 Resultados e Discussão.................................................... 51

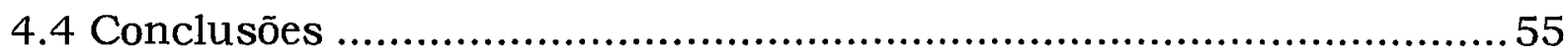

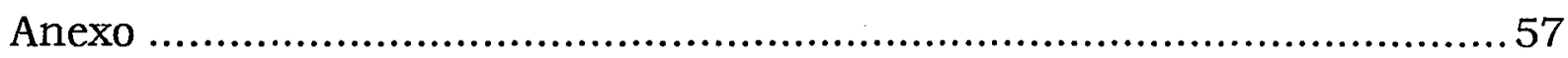

5 SELETIVIDADE DE HERBICIDAS EM PRÉ E PÓS-EMERGÊNCIA AO ADUBO VERDE PERENE Arachis pintoi ......................................... 59

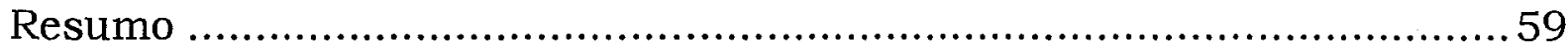

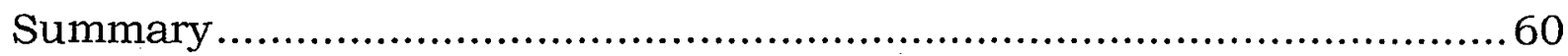

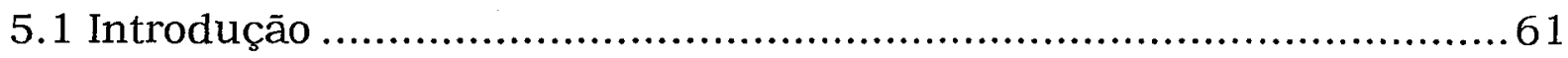

5.2 Material e Métodos................................................................ 63

5.3 Resultados e Discussão.................................................... 67

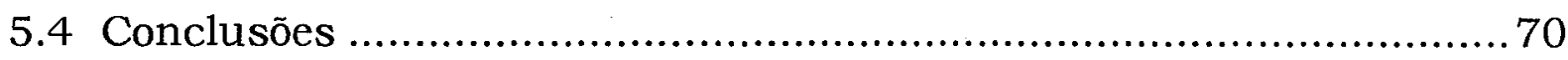

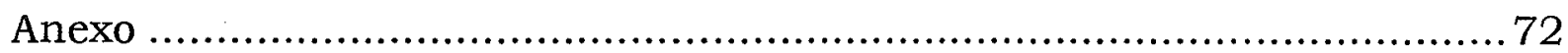

6 CORRELAÇÕES ENTRE A PROFUNDIDADE DE INCORPORAÇÃO DA FITOMASSA DE ADUBOS VERDES E A SUPRESSÃO DE PLANTAS

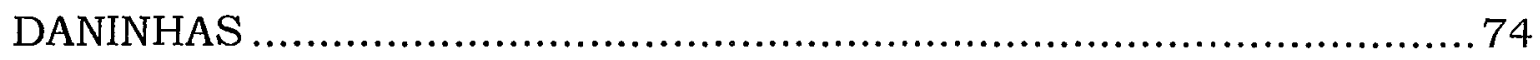

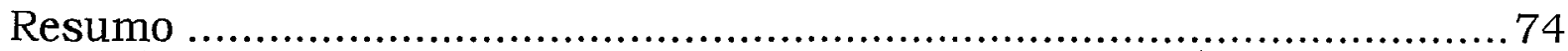

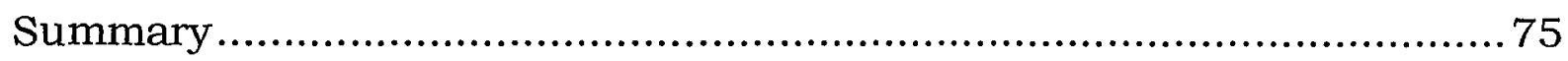

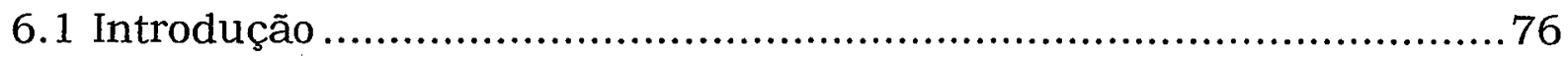

6.2 Material e Métodos.................................................................. 80

6.3 Resultados e Discussão......................................................... 84

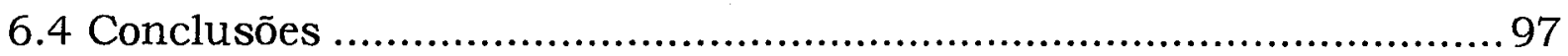

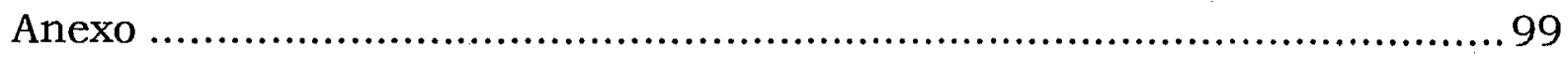

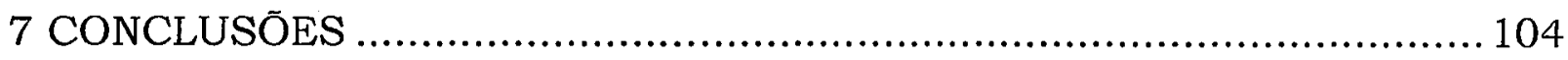

REFERÊNCIAS BIBLIOGRÁFICAS ............................................ 107 


\section{LISTA DE FIGURAS}

Página

6.1 Gráfico do número de plantas daninhas por vaso em função de adubos verdes aplicados em cobertura no solo.................. $\quad 86$

6.2 Gráfico do número de plantas daninhas por vaso em função de adubos verdes aplicados em cobertura no solo.................. $\quad 86$

6.3 Gráfico da biomassa seca de plantas daninhas por vaso em função de adubos verdes aplicados em cobertura no solo........ 87

6.4 Gráfico da biomassa seca de plantas daninhas por vaso em função de adubos verdes aplicados em cobertura no solo........

6.5 Gráfico do número de plantas daninhas por vaso em função do adubo verde incorporado no solo

6.6 Gráfico do número de plantas daninhas por vaso em função do adubo verde incorporado no solo.

6.7 Gráfico do número de plantas daninhas por vaso em função do adubo verde incorporado no solo.

6.8 Gráfico do número de plantas daninhas por vaso em função do adubo verde incorporado no solo.

6.9 Gráfico de produção de biomassa seca por vaso em função do adubo verde incorporado no solo.

6.10 Gráfico de produção de biomassa seca por vaso em função do adubo verde incorporado no solo.

6.11 Gráfico de produção de biomassa seca por vaso em função do adubo verde incorporado no solo

6.12 Gráfico de produção de biomassa seca por vaso em função do adubo verde incorporado no solo..

6.13 Gráfico do número de plantas daninhas por vaso em função dos adubos verdes incorporados no solo.

6.14 Gráfico do número de plantas daninhas por vaso em função dos adubos verdes incorporados no solo. 
6.15 Gráfico do número de plantas daninhas por vaso em função dos adubos verdes incorporados no solo............................... 95

6.16 Gráfico do número de plantas daninhas por vaso em função dos adubos verdes incorporados no solo............................... 95

6.17 Gráfico da produção de biomassa seca por vaso em função

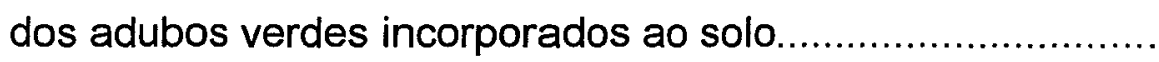

6.18 Gráfico da produção de biomassa seca por vaso em função dos adubos verdes incorporados ao solo. 


\section{LISTA DE TABELAS}

Página

3.1 Dados pluviométricos e de temperatura mensais (durante os meses de condução de ensaio). Experimento de campo. Piracicaba, 2000 - USP/ESALQ...................

3.2 Análise física do solo onde foi instalado o experimento (Análise granulométrica). Experimento de campo. Piracicaba, 2000 - USP/ESALQ

3.3 Análise química do solo onde foi instalado o experimento. Experimento de campo. Piracicaba, 2000 USP/ESALQ .................................................

3.4 Médias de densidade de plantas daninhas (plantas $/ \mathrm{m}^{2}$ ) - $1^{\text {a }}$ avaliação realizada aos 30 dias após instalação do experimento. Experimento de campo. Piracicaba, 2000 USP/ESALQ

3.5 Médias de densidade de plantas daninhas (plantas $/ \mathrm{m}^{2}$ ) - $2^{a}$ avaliação realizada aos 60 dias após instalação do experimento. Experimento de campo. Piracicaba, 2000 USP/ESALQ.

3.6 Médias de produção de biomassa seca de plantas daninhas $\left(\mathrm{g} / \mathrm{m}^{2}\right)-1^{\text {a }}$ avaliação realizada 30 dias após a instalação do experimento. Experimento de campo. Piracicaba, 2000 - USP/ESALQ.................................

3.7 Médias de produção de biomassa seca de plantas daninhas $\left(\mathrm{g} / \mathrm{m}^{2}\right)-2^{\mathrm{a}}$ avaliação realizada 60 dias após a instalação do experimento. Experimento de campo. Piracicaba, 2000 - USP/ESALQ 
3.8 Médias de produção de biomassa seca dos adubos verdes $\left(\mathrm{g} / \mathrm{m}^{2}\right)$ aos 120 dias após a instalação do experimento. Experimento de campo. Piracicaba, 2000 USP/ESALQ

3.9 Resumo do Quadro de Análise de Variância das avaliações de densidade e biomassa seca das plantas daninhas. Experimento de campo. Piracicaba, 2000 USP/ESALQ ..................................................

3.10 Resumo do Quadro da Análise de Variância da avaliação de biomassa seca dos adubos verdes. Experimento de campo. Piracicaba, 2000 - USP/ESALQ.

4.1 Número de plantas daninhas por vaso que germinaram em solo provenientes de áreas com os adubos verdes, aos 30 dias após instalação do experimento. Experimento de casa-de-vegetação - Piracicaba, 2000 USP/ESALQ .......................................................

4.2 Número de plantas daninhas por vaso que germinaram em solo provenientes de áreas com os adubos verdes, aos 60 dias após instalação do experimento. Experimento de casa-de-vegetação - Piracicaba, 2000 USP/ESALQ

4.3 Resumo do Quadro da Análise de Variância do Experimento.

5.1 Tratamentos utilizados no experimento instalado em condições de pré-emergência - Experimento de casa-devegetação. Piracicaba, 2000 - USP/ESALQ

5.2 Tratamentos utilizados no experimento instalado em condições de pós-emergência. - Experimento de casade-vegetação. Piracicaba, 2000 - USP/ESALQ 
5.3 Médias de produção de biomassa seca (g/vaso) e de fitotoxicidade do Arachis pintoi submetido a aplicações de herbicidas em pré-emergência. Experimento de cașade-vegetação. Piracicaba, 2000 - USP/ESALQ...............

5.4 Médias de produção de biomassa seca (g/vaso) e de fitotoxicidade do Arachis pintoi submetido a aplicações de herbicidas pós-emergentes. Experimento de casa-devegetação. Piracicaba, 2000 - USP/ESALQ...................

5.5 Resumo do Quadro de Análise de Variância da produção de biomassa seca do Arachis pintoi submetido a aplicaçōes de herbicidas pré e pós-emergentes. Experimento de casa-de-vegetação. Piracicaba, 2000 USP/ESALQ ..................................................

6.1 Descrição dos fatores utilizados no delineamento do esquema fatorial $3 \times 6 \times 3 \times 2$. Experimento de casa-devegetação. Piracicaba, 2000 - USP/ESALQ.

6.2 Resumo do Quadro da Análise de Variância, do ensaio utilizando adubação verde na superficie do solo. Experimento de casa-de-vegetação. Piracicaba, 2000 USP/ESALQ......................................................

6.3 Apresentação dos quadrados médios (Prob.) do ensaio utilizando adubação verde na superficie do solo. Experimento de casa-de-vegetação. Piracicaba, 2000 USP/ESALQ ......................................................

6.4 Resumo do Quadro da Análise de Variância, do ensaio utilizando adubação verde incorporada ao solo. Experimento de casa-de-vegetação. Piracicaba, 2000 USP/ESALQ 
6.5 Apresentação dos quadrados médios (Prob.) do ensaio utilizando adubação verde incorporada ao solo. Experimento de casa-de-vegetação. Piracicaba, 2000 -

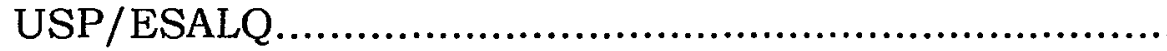




\title{
ADUBAÇÃO VERDE: EFEITOS SUPRESSIVOS SOBRE A INFESTAÇÃO DE PLANTAS DANINHAS E SELETIVIDADE DE HERBICIDAS
}

\author{
Autor: FRANCISCO JOSÉ SEVERINO \\ Orientador: Prof. Dr. PEDRO JACOB CHRISTOFFOLETI
}

\section{RESUMO}

Com o objetivo de avaliar os efeitos supressivos dos adubos verdes amendoim forrageiro (Arachis pintoı), crotalária (Crotalaria juncea L.) e feijão guandu anão (Cajanus cajan L. Millsp) sobre a infestação das plantas daninhas capim braquiária (Brachiaria decumbens Stapf.), capim colonião (Panicum maximum Jacq.), picão preto (Bidens pilosa L.) e infestação natural do terreno, composta basicamente por dicotiledôneas, bem como a seletividade de herbicidas ao amendoim forrageiro (Arachis pintoi), submetido a aplicações de herbicidas em pré e pós-emergência, foram instalados quatro experimentos, sendo um em condições de campo e três em condições de casa-de-vegetação, na Escola Superior de Agricultura "Luiz de Queiroz", Universidade de São Paulo, Departamento de Produção Vegetal, Piracicaba-SP. Os delineamentos experimentais utilizados foram de blocos casualisados, sendo que o experimento de campo foi instalado em parcelas subdivididas e os experimentos de casa-de-vegetação foram instalados em esquema fatorial. Os parâmetros avaliados durante a conđução dos experimentos, foram os seguintes: avaliações de contagem da infestação de plantas daninhas por vaso e ou por $\mathrm{m}^{2}$ (densidade), avaliações de 
produção de biomassa seca das plantas daninhas em g/vaso e dos adubos verdes em ton/ha, bem como para o amendoim forrageiro a produção de biomassa seca (g/vaso) e de fitotoxicidade de herbicidas (Escala EWRC) quando submetido a aplicações de herbicidas em pré e pós-emergência. Os resultados permitiram concluir que a utilização de adubos verdes contribui, significativamente, na redução de populações das plantas daninhas testadas, auxiliando, de maneira sustentável, no manejo integrado de plantas daninhas, sendo que as infestações são suprimidas de forma diferenciada pelos adubos verdes. Conclui-se ainda que, as aplicações de herbicidas pré-emergentes, de forma geral, causaram menor fitotoxicidade e, conseqüentemente, menor redução na produção de biomassa seca do amendoim forrageiro (Arachis pintoi), do que os herbicidas aplicados em pós-emergência. Sendo assim, alguns destes herbicidas podem ser utilizados na prática tanto para o controle do crescimento do adubo verde, evitando assim a competiçāo deste com a cultura principal, quanto para o controle de plantas daninhas que eventualmente infestam a área, principalmente no estabelecimento inicial do Arachis pintoi. 


\title{
COVER CROP: SUPRESSIVE EFFECTS ON WEED INFESTATION AND SELECTIVITY OF HERBICIDES
}

\author{
Author: FRANCISCO JOSÉ SEVERINO \\ Adviser: Prof. Dr. PEDRO JACOB CHRISTOFFOLETI
}

\section{SUMMARY}

To study the suppressive effect of the cover crops Arachis pintoi, Crotalaria juncea L. and Cajanus cajan L. Millsp. on the weed infestation of Brachiaria decumbens Stapf., Panicum maximum Jacq., Bidens pilosa L., and natural weed infestation in the area, mostly dicotyledonous, as well as the herbicide selectivity sprayed in pre and post emergence conditions of Arachis pintoi, four experiments were installed, being one in field conditions and three in greenhouse conditions of the Plant Production Department of ESALQ - University of São Paulo, Piracicaba - SP - Brazil. The experimental design used in the experiments was randomized complete blocks, with four replications, being the field experiment with subplots and the greenhouse experiments were installed in factorial design. The data collected during the experiments conduction were weed density in plant/pot or plant $/ \mathrm{m}^{2}$, weed dry biomass production in $\mathrm{g} / \mathrm{pot}$, and cover crop biomass yield in ton/ha, and fitotoxicity (EWRC rating) to Arachis pintoi by pre and post emergence herbicides. The results allowed the conclusions that the use of cover crop suppress, significantly, the weeds infestations, being an important tool in the sustainable integrated weed management. The weeds are suppressed in different intensity, 
depending on the cover crop planted. It was also concluded from the experiments, that the pre emergence application of herbicides, in general, causes lower fitotoxicity and, consequently, lower reduction to the biomass yield of Arachis pintoi, when compared to post-emergence herbicide application. So, some of these herbicides can be applied in the field in order to control the cover crop development so avoiding competition with the main crop, and to control weeds that eventually scape control by the green manure, especially in areas where Arachis pintoi has to be established by the first time. 


\section{INTRODUÇĀO}

Os seres vivos habitam comunidades dinâmicas, definidas por fatores físicos, químicos, biológicos e por interações que entre eles se estabelecem, das quais, a grande maioria, ainda é pouco conhecida (Almeida, 1988). Esse mesmo autor cita que as interações que se desencadeiam entre os individuos das comunidades foram denominadas, por Muller (1966) ${ }^{1}$, de interferências.

Assim, a produtividade agricola de uma determinada cultura é regulada por uma série de fatores, alguns dos quais podem ser modificados pelo homem em favor da cultura, tais como variedade, teor de nutrientes e água no solo, insetos, patógenos e plantas daninhas.

As plantas daninhas são, sem dúvida, um dos mais importantes fatores que afetam a economia agrícola, em caráter permanente. Portanto, se por um lado a sua presença, em altas densidades, na cultura, ocasiona prejuizos inquestionáveis devido às diversas formas de interferências negativas, como competição, amensalismo e parasitismo, por outro, o seu controle ainda acarreta, na maioria das vezes, um aumento significativo no custo de produção (Christoffoleti, 1988).

${ }^{1}$ MULLER, C. H. The role of chemical inhibition (Allelopathy) in vegetation competition. BULLETIM OF THE TORREY BOTANICAL CLUB, v.93, n.5, p.322-51, 1966. 
Atualmente, o controle de plantas daninhas tem sido feito, na sua grande maioria, através de métodos manuais, mecânicos e principalmente pelo método químico, com o uso de herbicidas.

Porém, estas medidas, utilizadas isoladamente, não são suficientes para eliminar toda a interferência negativa das plantas daninhas na cultura, o que exige, então, medidas integradas de controle.

Considerando que o preparo do solo, bem como o tipo de vegetação predominante na área antes do plantio da cultura influem de maneira decisiva na intensidade de infestação, a prática de rotação de culturas, incluindo o uso de adubos verdes, traz beneficios no controle de plantas daninhas, além de outras vantagens técnicas, econômicas e ecológicas proporcionadas por este tipo de prática agrícola.

Em áreas com sistema de produção conservacionista, em que se adota o sistema de plantio direto, onde se deixa uma fitomassa na superficie do solo, a infestação de plantas daninha é afetada por fatores físicos, químicos e biológicos. Dentre os fatores fisicos destaca-se a dificuldade da emergência da planta daninha, que apresenta poucas reservas em suas sementes para atravessar a camada de fitomassa, e a dormência das sementes que necessitam de luz para germinarem (sementes fotoblásticas positivas). A produção de inibidores bioquímicos, diretamente pelos restos vegetais ou pelos microorganismos, que se desenvolvem durante seu processo de decomposição, pode também inibir a germinação e emergência de algumas espécies. E finalmente, a condição de microambiente, ocasionada por esta fitomassa, aumenta a população microbiana na superfície do solo e nos primeiros centimetros do perfil, de tal forma que diversas sementes de plantas daninhas podem se deteriorar ou serem predadas.

Atualmente, a pressão econômica, social e ecológica, para limitar o uso de agrotóxicos nos sistemas de produção, está 
impulsionando a pesquisa na busca de procedimentos alternativos, que promovam menor impacto ambiental e social. No Brasil, há atualmente um novo despertar para essa consciência e inicia-se um avanço das pesquisas nesta área. No entanto, diante da enorme diversidade biológica e ambiental, os estudos ainda são muito limitados.

Desta forma, no presente trabalho, procurou-se estudar o efeito da influência de três adubos verdes, amendoim forrageiro (Arachis pintoi), crotalária (Crotalaria juncea L.) e feijāo guandu anão (Cajanus cajan (L.) Millsp.), sobre a dinâmica de populações de três espécies de plantas daninhas, Brachiaria decumbens Stapf., Panicum maximum Jacq. e Bidens pilosa L., e sobre a infestação natural de plantas daninhas da área, onde foi realizado o experimento. Além disso, foi estudada a seletividade de herbicidas ao Arachis pintoi.

O objetivo principal foi de disponibilizar informações técnicas, embasadas cientificamente, que possam ser utilizadas de maneira prática, no manejo integrado das plantas daninhas, visando reduzir o uso de herbicidas nos mais diversos agroecossistemas e, procurando-se, assim, contribuir positivamente para um desenvolvimento agrícola sustentável. 


\section{REVISÃO DE LITERATURA}

\subsection{Rotação de culturas}

A rotaçāo de culturas foi definida por Curl (1963), como sendo o cultivo econômico de plantas em sucessão ou em seqüência definida, numa mesma área. Salientou ainda, que no início da agricultura, o homem sabia que o monocultivo contínuo do solo, sem complementação eventual da fertilidade, diminuía a produtividade das culturas subseqüentes. Por isso, os romanos já sabiam, há 2000 anos atrás, dos beneficios da seqüência de culturas. O autor realizou também uma revisão bibliográfica sobre os mecanismos de controle das doenças de plantas através da rotação de culturas.

Yoon \&. Kok $(1969)^{2}$, citados por Christoffoleti (1988), estudaram os efeitos benéficos de algumas leguminosas, usadas como adubo verde em áreas de reforma da cultura de cana-de-açúcar, sendo que, dentre elas estava a cultura de amendoim (Arachis hypogaea L.). Foi deixada uma testemunha, onde o solo permaneceu em pousio com a infestação natural de plantas daninhas. No preparo de solo para o plantio de cana-de-açúcar foi incorporado toda a massa vegetal produzida pelos adubos verdes, e os restos da cultura do amendoim. Nos resultados de produção de cana-de-açúcar, foi observada uma

2 YOON, C. N.; KOK, C. A. A note of green manuring in sugar cane cultivation. THE MALAYSIAN AGRICULTURAL JOURNAL. Kuala Lampur: v.47, n. 1, p.14-20, 1969. 
superioridade dos tratamentos que foram rotacionados com leguminosas, quando comparados com a testemunha. A maior produtividade foi obtida nas parcelas que foram rotacionadas com a cultura de amendoim.

Vários são os trabalhos sobre os efeitos benéficos da rotaçāo de culturas no controle de populações de nematôides no solo. Aguilera et al. (1985), estudaram especificamente os efeitos da rotação de culturas, em solo franco arenoso com baixo teor de matéria orgânica e alta população de nematóides dos gêneros Meloidogyne, Pratylenchus, Helicotylenchus e Criconemoides, no municipio de Santa Cruz do Rio Pardo - SP. Verificaram que o manejo do solo, através da prática da rotação de culturas propiciou beneficios ao solo com reflexos positivos na produção, reduzindo as populações de nematóides.

Segundo Aurvalle et al. (1985), a prática da rotação de culturas consiste no cultivo de diferentes espécies de plantas sobre uma mesma área, alternadamente. Como conseqüência obtém-se melhora da fertilidade do solo, controle de erosão, pragas, doenças e plantas daninhas. Porém, a seqüência de culturas deve levar em conta as interferências positivas ou negativas de uma espécie sobre a seguinte, no que se refere a substâncias tóxicas, necessidades de nutrientes e alteração da estrutura do solo. Ainda segundo o autor, as leguminosas, podem ser sempre utilizadas, tanto para a produção de forragem, grãos e fibras, quanto para adubação verde.

França \& Moreira (1988), conceituam rotação de culturas como sendo a sucessão de diferentes culturas sobre o mesmo solo. Segundo os autores, seu principio fundamental é muito simples: alternam-se culturas que tenham modos diferentes de explorar o solo. Desta maneira, as raízes das diversas plantas que se sucedem poderāo explorar todas as camadas do solo e usar, dentro das proporções equilibradas, todos os elementos ai contidos. Ainda, de acordo com os 
autores, num sistema de rotação é fundamental incluir a adubação verde, pois o adubo verde fornecerá matéria orgânica em proporção relativamente grande dentro de um curto periodo. Assim, a cultura de leguminosas constitui uma prática racional e difundida para esta situação. Também, os mesmos autores, lembram que num programa de rotação de culturas, o plantio em seqüência de grupos de plantas que nāo possuam pragas e doenças em comum deve ser observado. Deve-se também alternar culturas exigentes, que demandem matéria orgânica abundante, e culturas menos exigente's, que suportem uma fertilidade orgânica moderada.

A diversidade de culturas no tempo (rotações) e no espaço (cultivo múltiplo), de acordo com Paschoal (1994), apresenta como vantagens: controle de plantas daninhas, quebra do ciclo biológico de pragas e patógenos, controle de erosão, melhora das condições físicas, químicas e biológicas dos solos e, conseqüentemente, maiores retornos econômicos para os produtores.

\subsection{Efeitos da rotação de culturas sobre a população de plantas daninhas}

De acordo com Coble $(1980)^{3}$, citado por Christoffoleti (1988), a rotação de culturas foi muito pesquisada no passado, embora a maioria destas pesquisas não estivessem relacionadas com o controle de plantas daninhas.

Até o final da década de 40, o cultivo manual e mecânico e a rotação de culturas foram os principais métodos de controle das plantas daninhas nos Estados Unidos da América do Norte.

3 COBLE, H. D. Crop rotation and monoculture - weed control. CROPS AND SOIL. American Society of Agronomy. v.32, n.5, p.1-32, 1980. 
Segundo Walker \& Buchanan (1982), as plantas daninhas nocivas tem grande dificuldade em manter uma população em uma determinada área quando se emprega uma rotação sistemática de culturas de gramineas com outras espécies de plantas cultivadas.

Leighty (1938), relatou que o principal objetivo da rotação de culturas é manter a fertilidade do solo. Ele reconheceu a importância da rotação de culturas no controle de plantas daninhas, assim como suas vantagens no controle de doenças de plantas e erosão. Ainda outros beneficios foram apontados na rotação de culturas: aumento do teor de nitrogênio no solo pelas leguminosas, melhor distribuição da mão-deobra devido a diversificação das culturas e aumento nas produções das culturas. O mesmo autor, mencionou que a rotação de culturas, quando realizada com sementes isentas de sementes de plantas daninhas, é o método mais eficaz já utilizado para manter o solo livre de plantas daninhas. Nenhuma outra forma de controle de plantas daninhas, mecânico, químico ou biológico, é tão econômico ou fácil de ser. praticado como uma bem arranjada seqüência de cultivos e culturas. Nem todas as plantas daninhas podem ser controladas pela rotação de culturas, porém, infestações de plantas daninhas consideradas problemas são provavelmente menos severas onde as diversificaçōes de culturas são praticadas, quando comparada com áreas de prática de monocultivo.

Em áreas de monocultura, cujas práticas agrícolas são repetidas ao longo dos anos, sem modificações, podem surgir plantas daninhas resistentes, causando modificações na flora infestante (Maxwell et al., 1990; Blair, 1991). 
Segundo Walker \& Buchanan (1982), citados por Christoffoleti (1988), após a década de 40, com a introdução das fontes sintéticas de nitrogênio, a utilização da rotação de culturas começou a diminuir nos Estados Unidos da América do Norte, pois a adubação mineral substituia a melhora nas propriedades quimicas do solo, ocasionada pelas leguminosas. Com o abandono da rotação de culturas, algumas plantas daninhas tornaram-se problemas, em virtude da indisponibilidade de herbicidas para o seu controle. Um exemplo clássico desta situação foi o uso do herbicida 2,4-D, amplamente aplicado para o controle de plantas daninhas do tipo folhas largas na cultura do milho e, em menos de 10 anos, as plantas daninhas do tipo gramineas anuais passaram a ser um problema sério, até que novos herbicidas fossem desenvolvidos para o controle das gramíneas.

Neme et al. (1954), verificaram, num dos trabalhos pioneiros no Brasil sobre os efeitos da rotação de culturas na população de plantas daninhas, a relativa ação do feijāo-de-porco (Canavalia ensiformis DC.), como inibidor do desenvolvimento das plantas de tiririca (Cyperus rotundus L.) em área de cultivo do milho.

Dowler et al. (1974), cultivaram milho, algodão, amendoim e soja continuamente ou em rotação, onde as plantas daninhas foram controladas através de métodos culturais, ou com o uso de herbicidas de ação sobre folhas largas. A rotação de culturas diminuiu muito o número de plantas daninhas, porém a composição matofloristica não foi alterada de forma significativa. O controle foi realizado através de capinas manuais e cultivos mecanizados, sendo que quando comparados com os herbicidas, este método de controle permitiu um maior número de plantas daninhas na colheita, tanto nas culturas em

4WALKER, R.H.; BUCHANAN, G.A. Crop manipulation in integrated weed management systems. WEED SCIENCE, v.30 ( suppl. 1 ), p.17-24, 1982. 
rotação como no cultivo contínuo de uma mesma cultura, especialmente na cultura do milho. A rotação de culturas não alterou o número de horas homem/ha para realizar as capinas necessárias após três cultivos mecânicos na cultura do milho ou quatro cultivos na cultura do algodão.

De acordo com Marzocca (1976), a rotação de culturas permite controlar muitas espécies de plantas daninhas que vivem em sincronismo com determinada cultura. Ela deve ser programada de tal maneira, que interrompa o ciclo biológico das plantas daninhas comuns e mais difundidas, utilizando culturas competitivas e técnicas culturais adequadas regionalmente. A rotação de culturas, quando acompanhada do uso de sementes isentas de plantas daninhas, torna-se um método muito eficiente para manter o solo livre de espécies de plantas não desejáveis. Uma sucessão bem arranjada de culturas e técnicas culturais adequadas é um procedimento fácil de ser empregado e muito econômico.

Coble (1980) $)^{5}$, citado por Christoffoleti (1988), ressaltou que a rotação de culturas deve ser escolhida de acordo com as plantas daninhas infestantes em situações particulares, assim como de acordo com a situação de infestação que cada produtor encontra em sua propriedade. Caso todas as plantas daninhas, que infestam a área, possam ser controladas por outros métodos de controle, então a rotação de culturas não é necessária como parte do programa de manejo integrado de plantas daninhas adotado na propriedade. Assim, é importante que o agricultor faça um levantamento das plantas daninhas que infestam sua área, e só então decidir se a rotação de culturas é

5COBLE, H. D. Crop rotation and monoculture - weed control. CROPS AND SOIL. American Society of Agronomy. v.32, n.5, p.1-32, 1980. 
importante ou não no seu sistema de manejo integrado das plantas daninhas.

Desenvolver um sistema de manejo integrado de plantas daninhas é uma tarefa complexa, podendo ser mais eficiente se houver um completo entendimento da dinâmica populacional das plantas daninhas. Desta maneira, deve-se levar em consideração que cada população é composta por individuos em diferentes estágios funcionais, os quais interagem com outros individuos da mesma população ou não, e com o ambiente (Fernández-Quintanilla, 1988).

Poucas são as pesquisas sobre a influência da rotação ou seqüência de culturas sobre determinadas espécies ou populações de plantas daninhas. O efeito da rotação de culturas sobre as plantas daninhas é conhecido, no entanto, através de estudos dos aspectos qualitativos e não quantitativos (Zimdahl, 1980).

Segundo Anderson (1983), quando as mesmas práticas culturais são utilizadas ano após ano, em um mesmo local, certas espécies de plantas daninhas, que estão associadas com aquelas práticas, tendem a se reproduzir com mais rapidez e são, assim, mais competitivas que a cultura, reduzindo a produção, qualidade e beneficios econômicos.

A rotação de culturas impede ou reduz a formação de altas populações de determinadas espécies de plantas daninhas, que estão associadas a uma cultura continuamente cultivada num mesmo local. No entanto, para isto, a escolha da cultura a ser rotacionada é importante, pois deve ser dado preferência para aquelas culturas cujas características culturais e de crescimento são opostas às da cultura anterior e das plantas daninhas problemáticas predominantes na área. Além de controlar plantas daninhas, a rotação de culturas aumenta a produção agrícola e a qualidade das culturas, melhora as propriedades 
fisicas e químicas do solo e contribui, significativamente, no controle de pragas e doenças das culturas (Christoffoleti, 1988).

Sempre na busca de umá visão integrada, isto é, procurando-se observar a inter-relação dos fatores que ocorre num agroecossistema e também por fazer parte do objetivo deste trabalho, é de fundamental importância relacionarmos rotação de culturas com alelopatia. Rice (1983), definiu alelopatia como sendo qualquer efeito causado por uma planta viva ou em decomposição, incluindo microorganismos, que direta ou indiretamente seja prejudicial a outra planta, através de compostos químicos lançados no ambiente.

Segundo Almeida (1988), a alelopatia é um dos mecanismos de interferência que ocorre entre os seres vivos de uma comunidade e é provocada pela introdução, no ambiente em que vivem, de substâncias quimicas por eles elaboradas e que afetam os individuos da comunidade. A introdução das substâncias no ambiente é feita através de tecidos vivos ou pela decomposição dos tecidos mortos. O termo alelopatia considera os efeitos prejudiciais e benéficos provocados por um organismo (doador) sobre outro (receptor).

Uma das aplicações de uso prático da alelopatia é a redução do uso de herbicidas no sistema de plantio direto, devido à redução da população de plantas daninhas, em função do efeito conjunto do não revolvimento do solo e da ação alelopática de substâncias liberadas pela palhada que cobre o solo. Em culturas de feijão, milho e soja, implantadas em sistema de plantio direto, em solos com baixa infestação, pode-se dispensar o uso de herbicidas quando a semeadura é feita sobre a palha de aveia-preta. A palha de centeio é menos eficiente na inibição de plantas daninhas e requer o uso de herbicidas de contato para eliminar as que se encontrem estabelecidas no terreno, antes da semeadura das culturas de verão. No estado do Paraná, agricultores que adotaram o sistema de plantio direto recorrem 
eventualmente à capina de reboleiras de plantas daninhas onde a cobertura morta foi menos eficiente na sua eliminação. Assim, para manterem suas lavouras com baixa intensidade de infestaçāo, esses agricultores as conservam livres de plantas daninhas durante as entressafras (Almeida, 1988).

De acordo com Christoffoleti (1988), conhecer mais profundamente as relações alelopáticas das plantas cultivadas e das plantas daninhas pode permitir uma melhora nos sistemas de cultivo, particularmente na rotação de culturas, épocas e processos de semeadura e outras práticas agrícolas. No Brasil uma grande contribuição para este conhecimento foi dada por Almeida (1985), que observou a existência de uma correlação linear entre a quantidade de palha deixada na superficie do solo por uma cultura em rotação e a infestação de plantas daninhas na cultura em seqüência.

Aldrich (1984) e Putnam (1985), estabeleceram os postulados da alelopatia para a comprovação dos efeitos alelopáticos nos agroecossistemas, os quais são semelhantes aos postulados de Kock, utilizados na fitopatologia, para a comprovação da incidência de uma doença. É necessário, para a comprovação da alelopatia que os efeitos sejam inicialmente observados no campo, para que depois seja isolado e identificado estruturalmente o componente químico para sua sintese artificial e aplicação no campo, reproduzindo assim os sintomas inicialmente descritos. Estes postulados exigem procedimentos caros de pesquisa e com certo grau de dificuldade para sua execução. Assim, são raras as comprovações da alelopatia na prática, mas, para Zimdahl (1993), tais comprovações são substanciais caso as pesquisas com alelopatia caminhem para a descrição das causas.

Assim sendo, pode-se dizer que os esforços da pesquisa têm se concentrado no uso de coberturas vegetais para reduzir a população de plantas daninhas. No entanto, quanto mais se conhecer sobre os 
mecanismos de seletividade dos aleloquímicos, seu modo de ação fisiológico e a regulação genética de sua biosíntese, maior será o sucesso em manipular as fontes de germoplasma para selecionar as substâncias alelopáticas, aumentar sua produção ou regular sua taxa de liberação para prolongar seu período de ação.

\subsection{Adubação verde}

Muitas vezes, principalmente nas condições tropicais, o manejo inadequado do solo pode trazer, através dos cultivos, conseqüências drásticas, exaurindo-o de suas reservas orgânicas e minerais, transformando-o em solo de baixa fertilidade, tornando-se necessário o emprego constante de práticas agrícolas que visam amenizar essas conseqüências (Mello \& Brasil Sobrinho, 1960).

Com a prática da adubação verde, é possivel recuperar a fertilidade dos solos, proporcionando aumento do teor de matéria orgânica, da capacidade de troca de cátions e da disponibilidade de macro e micro nutrientes; formação e estabilização de agregados; melhoria da infiltração de água e aeração; diminuição diuturna da amplitude de variação térmica; controle de nematóides e, no caso das leguminosas, incorporação ao solo de nitrogênio, efetuada através da fixação biológica (Igue, 1984).

A adubação verde é uma das práticas agrícolas que nos agroecossistemas recicla, de forma semelhante a uma floresta, maior quantidade de energia. É importante ressaltar, que em solos degradados, a adubação verde cumpre o papel que um aporte de matéria orgânica, não cumpriria integralmente (Piamonte, 1996). Ainda, segundo esse autor, as adubações, incluindo-se aqui a adubação verde, devem ser entendidas como a prática de vitalização da terra, ou seja, 
conferir ao solo elementos que permitam o estímulo crescente de seu complexo biótipo. Um solo, adquiriria, então, a tendência a tornar-se inteiramente vivo, semelhante aos vegetais.

A adubação verde diz respeito a um cultivo de plantas com o objetivo de adubação, o avivamento do solo e o seu melhoramento. Com isto, a meta da adubação verde é claramente traçada: assegurar e melhorar a fertilidade do solo nos agroecossistemas (Vogtmann \& Wagner, 1987). Assim, segundo esses mesmos autores, a prática da adubação verde proporciona: abastecimento do solo com material orgânico, enriquecimento do solo com substâncias nutritivas disponiveis e elementos traços, melhoramento da estrutura do solo, intensificação da atividade biológica do solo, diminuição da lixiviação de nutrientes, utilização de plantas de adubação verde como forragem intermediária e, diminuição da incidência de pragas, patógenos e plantas daninhas nas culturas.

França \& Moreira (1988), citaram que um dos sistemas de pousio bastante propagado é a adubação verde, geralmente usando-se leguminosas. As leguminosas seriam plantadas e, atingindo o ponto de florescimento, cortadas e incorporadas mecanicamente ao solo ou seriam mantidas como cobertura viva no solo até pouco antes da maturação das sementes, quando seriam incorporadas ou preferencialmente cortadas e mantidas como cobertura morta. Segundo os autores, a matéria orgânica conseguida neste periodo é mais lignosa e, portanto, resiste mais à decomposição e também, quando possivel, as sementes podem ser colhidas e usadas para novos plantios ou vendidas, acrescentando uma renda extra á unidade produtiva.

Nas últimas décadas houve uma diminuição no uso da adubação verde, devido a intensificação dos cultivos e aumento da disponibilidade de fertilizantes químicos (Singh et al., 1991). 
No entanto, nos últimos anos, observa-se a procura de um sistema de produção agrícola que seja capaz de recuperar a fertilidade do solo, incluindo o uso de leguminosas como cobertura no outonoinverno, que tem apresentado resultados satisfatórios, na obtenção de renda extra e quanto aos efeitos benéficos na cultura subseqüente (Bulisani et al., 1987).

De acordo com Franco \& Souto (1984), as leguminosas geralmente usadas em adubação verde, fixam em média, $188 \mathrm{~kg}$ de $\mathrm{N} / \mathrm{ha} / \mathrm{ano}$, sendo este adicionado ao solo, podendo assim racionalizar o uso de nitrogênio. Kohl et al. (1971), mencionaram que, com esta prática pode-se recuperar a fertilidade do solo perdida devido ao manejo inadequado e à adoção de monocultivo, obter $\mathrm{N}$ para a cultura seguinte e evitar, desta forma, adubos altamente solúveis que podem poluir o ambiente.

No Brasil, a prática da adubação verde vem sendo utilizada há mais de trinta anos com excelentes resultados sob as mais diversas condições de produção (Miyasaka, 1984). Porém, embora sejam encontrados dados de pesquisa obtidos nas mais diversas instituições do país, indicando o efeito favorável na produção agrícola, a prática da adubaçāo verde ainda continua restrita a um número reduzido de agricultores (Freitas et al., 1984).

$\mathrm{Na}$ adubação verde, a razão da preferência pelas leguminosas é principalmente pelo fato destas, em simbiose com bactérias do gênero Rhizobium e Bradyrhizobium, fixarem $\mathrm{N}$ do ar em quantidade suficiente para satisfazer suas necessidades e gerar excedentes para a cultura que a sucede. Sua composição química e relação $\mathrm{C} / \mathrm{N}$ são outras importantes características. Porém, a adubação verde não supre o solo em relação às suas deficiências minerais totais, havendo necessidade, em solos deficientes de $\mathrm{P}, \mathrm{K}, \mathrm{Ca}, \mathrm{Mg}$, de se aplicar os referidos elementos. 
O sistema radicular das leguminosas pode alcançar elevadas profundidades com capacidade de absorver água e extrair elementos minerais destas camadas do solo, proporcionando assim, uma reciclagem e redistribuição de nutrientes. Contudo, o efeito das raizes na adubação verde é pouco estudado devido às dificuldades em se obter os dados.

Em fruteiras de clima temperado, principalmente figueiras, videiras e pessegueiros, já está sendo adotada, por alguns agricultores, a substituição da cobertura morta vegetal de palha de capim, restos de culturas ou bagaço de cana, pelo cultivo, nas entrelinhas, com leguminosas ou gramineas. Dentre as leguminosas destaca-se, o amendoim forrageiro (Arachis pintoi) pela sua adaptabilidade ao sistema. É crescente o interesse e a demanda por esta tecnologia por parte de alguns agricultores na região frutícola de Valinhos, município do Estado de São Paulo (Kiss, 1997). Também, Coleman (1995), cita a adoção da utilização do Arachis pintoi como adubo verde perene em pomares cítricos da Flórida, nos EUA e da Costa Rica.

A recomendação da adubação verde atém-se basicamente ao sistema de produção vigente em uma situação agrícola específica, devendo-se considerar, entretanto, a não interferência com as atividades agropecuárias principais da propriedade; o custo desta prática; a disponibilidade de sementes e, também, a preferência do agricultor (Wutke et al. 1993). Os autores ressaltam, ainda, a importância de se considerar as características próprias de cada espécie tais como adaptação edafoclimática (termo e fotoperiodo, disponibilidade hídrica, radiação solar), ciclo (anual, bianual e perene), porte da planta (rasteira ou ereta, podendo o cultivo ser arbustivo ou arbóreo), época de semeadura (verão ou inverno), produto final principal (grãos, fitomassa ou ambos), e, ainda, práticas culturais e fertilidade do solo que afetam sobremaneira a quantidade de fitomassa produzida e, 
conseqüentemente, o seu efeito. Este pode ainda ser obtido não só pela cobertura vegetal do solo, como também pela própria produção de grãos.

Sendo assim, um sistema de rotação de culturas empregando leguminosas traz, além dos beneficios citados, incremento na produtividade, economia de adubo nitrogenado na cultura que a sucede no esquema de rotação ou de sucessão e pode fazer parte, como uma valiosa ferramenta, de um sistema de manejo integrado de plantas daninhas (Wutke et al., 1993).

E, por último, Wutke et al. (1993), ressaltam que não devemos esquecer que os adubos verdes são plantas, assim como as outras, tem limitações quanto ao clima, solo e disponibilidade de água e que para a implantação de adubações verdes, independentemente da sua finalidade, não existem regras preestabelecidas e a experimentação local é de fundamental importância.

\subsection{Adubo verde perene}

Adubo verde perene pode ser definido como sendo uma cobertura vegetal viva que permanece no solo durante toda a estação de crescimento da cultura principal durante vários ciclos. Conseqüentemente, a competição direta por recursos essenciais de crescimento será a principal forma de supressão das plantas daninhas pelo adubo verde perene.

\subsubsection{Controle de plantas daninhas pelo adubo verde perene}

Um adubo verde perene pode potencialmente inibir a germinação e o estabelecimento de plantas daninhas com muito mais eficiência do que resíduos dessecados de culturas. Teasdale \& Daughtry (1993), verificaram que a clorofila, em uma vegetação viva intercepta a 
luz vermelha $(660 \mathrm{~nm})$ e em menor quantidade a luz vermelha distante $(710 \mathrm{~nm})$ numa taxa suficiente, de tal forma que a luz difusa que atinge a semente da planta daninha, localizada abaixo da folhagem do adubo verde, é induzida a dormência, pois o fitocromo é convertido para a forma inativa. A transmitância da luz e a amplitude térmica foram também reduzidas em maior intensidade pelos adubos verdes perenes, quando comparado com palhada dessecada. Não obstante, as plântulas que eventualmente emergem, debaixo da folhagem do adubo verde, estão em desvantagem competitiva quando em competição com um adubo verde perene.

As pesquisas realizadas com adubos verdes perenes têm mostrado uma redução nas populações de plantas daninhas em alguns sistemas de produção. Hartwig (1989), mostrou que Coronilla varia L., usada como cobertura viva de solo, na cultura do milho, reduziu a população da planta daninha dente-de-leão (Taraxacum officinale) em $74 \%$ quando comparada com áreas onde a palhada foi deixada na superficie para a realização de plantio direto. Enache \& Ilnicki (1990), verificaram melhor controle das plantas daninhas na cultura do milho, quando foi usada cobertura viva de plantas de Trifolium subterraneum L., sendo que, esta cobertura viva produz sementes subterrâneas. Esta conclusão foi tirada comparando o tratamento de cobertura viva com outros tratamentos com e sem o uso de herbicidas. White \& Scott (1991), mostraram que várias leguminosas perenes, depois de estabelecidas em culturas de cereais, reduziram a biomassa de plantas daninhas na área, quando comparada com a testemunha, sem a presença de cobertura. DeHaan et al. (1994), verificaram que em Brassica hirta, cultivada como adubo verde perene na cultura do milho, durante seis a oito semanas, reduziu, em média, $82 \%$ da biomassa das plantas daninhas infestantes na área, quando comparado com outros tratamentos. 
Embora os adubos verdes perenes possam ter um potencial para a supressão do desenvolvimento de certas espécies de plantas daninhas; a experiência sugere que o controle total das plantas infestantes, na natureza, dificilmente ocorre pela supressão causada por uma única espécie, mas sim existe sempre uma combinação de espécies de plantas para suprimir totalmente a planta daninha. Mesmo a melhor das leguminosas perenes desenvolve falhas no seu crescimento ou na ocupação de todos os nichos ecológicos, de tal maneira que alguma diversidade de espécies sempre ocorre. Espécies de plantas daninhas com uma fenologia e morfologia compativeis com o adubo verde podem tornar-se infestante da área. Wilkinson et al. (1987), relataram que a infestação de plantas daninhas constituiu-se na principal limitação no estabelecimento de Festuca arundinacea, usada como adubo verde perene para milho após três anos de estabelecimento. Mohler (1991), verificou o estabelecimento de uma população de plantas daninhas em Trifolium repens L., usado como adubo verde perene na cultura de milho doce, de tal maneira que reduziu a produção da cultura de milho, depois de quatro anos do estabelecimento do adubo verde perene. Embora os adubos verdes perenes possam ser ferramentas efetivas para o controle de plantas daninhas, eles requerem um manejo de plantas daninhas compativel, particularmente para prevenir a invasão e estabelecimento de espécies de plantas daninhas com o tempo.

\subsubsection{Controle do crescimento dos adubos verdes perenes}

Um adubo verde perene, que tem a capacidade de suprimir totalmente o desenvolvimento das plantas daninhas, provavelmente também é capaz de afetar a produção da cultura principal. A comparação entre várias gramineas e leguminosas, usadas como cobertura vegetal viva, mostrou que as culturas que foram mais 
supressivas para as plantas daninhas, foram também supressivas para a produção da cultura de milho (Echtenkamp \& Moomaw, 1989). Planta daninha e culturas de cereais foram suprimidas principalmente quando leguminosas perenes foram usadas como adubo verde, sendo que, esta maior supressão também coincidiu com os adubos verdes que produziram maior quantidade de biomassa (White \& Scott, 1991). Em um outro trabalho de pesquisa foi verificado que práticas de manejo que permitiram Brassica hirta suprimir o desenvolvimento de plantas daninhas, teve como conseqüência, também a redução do desenvolvimento da cultura de milho (De Haan et al., 1994). A intensidade da redução da infestação das plantas daninhas e da cultura principal está diretamente relacionada com a biomassa do adubo verde. Elkins et al. (1983) e Nicholson \& Wien (1983), mostraram que existe uma alta correlação entre a biomassa do adubo verde permanente e redução da produção da cultura principal. Desta maneira, o manejo do crescimento do adubo verde permanente é, portanto, essencial para o desenvolvimento e estabelecimento de adubos verdes permanentes em sistemas de produção.

\subsubsection{Amendoim forrageiro (Arachis pintoi) como adubo verde perene, sua origem e classificação botânica}

Nativa do Brasil Central, ela precisou ser pesquisada no exterior para que seu valor fosse reconhecido por aqui. Embora parente próximo do amendoim consumido pelo homem, pois ambas fazem parte do gênero Arachis na classificação botânica, a leguminosa Arachis pintoi ou amendoim forrageiro, quase sempre foi vista no Brasil como nada mais do que uma planta infestante, muitas vezes de dificil manejo. Quem descobriu primeiro suas qualidades foram os pesquisadores do Centro Internacional de Agricultura Tropical da Colômbia, que levaram 
do país diversas espécies do gênero Arachis e, depois de uma seleçāo, conseguiram bons resultados na cobertura do solo e adubação verde permanente em pomares de cítricos do estado da Flórida, nos Estados Unidos da América do Norte, e da Costa Rica (Kiss, 1997).

No ano de 1995, iniciou-se uma série de experimentaçōes, em Valinhos, municipio do estado de São Paulo, por um pequeno grupo de produtores de figo que receberam as sementes para fazer testes em suas plantações. Como o cultivo do figo exige a cobertura do solo do pomar, os agricultores da região de Valinhos estavam habituados, desde a década de 70 , a usar cobertura morta de capim-gordura, cortado na forração de suas terras. No entanto, esta prática se tornou inviável com o tempo, pois a mão-de-obra para o corte se tornou escassa e seu custo elevado. Para forrar um hectare de figo é preciso dispor de dois hectares de pasto. A segunda alternativa foi o bagacilho de cana, resíduo do processamento da cana-de-açúcar, mas o preço alto e, por se tratar de uma cobertura morta facilmente arrastada pelas chuvas inviabiliza seu uso (Kiss, 1997).

Com o amendoim forrageiro isso não acontece. Ele é plantado no início da estação das águas (outubro e novembro) como época ideal, mas é possivel também o plantio no final das chuvas. Seu desenvolvimento é relativamente rápido, isto é, em quatro a seis meses já oferece uma boa cobertura do solo. As sementes têm ainda preço alto e há pequena disponibilidade no mercado, porém o produtor pode produzir mudas da planta que se propaga também por estolhos e, por ser uma planta perene dispensa a forração anual, além de propiciar os beneficios técnicos, econômicos e ecológicos da adubação verde nos diversos sistemas de produção agrícola (Kiss, 1997).

De acordo com Coleman (1995), o amendoim forrageiro está sendo muito adotado e difundido por produtores de citros do estado da Flórida, nos Estados Unidos da Améria do Norte, pela sua habilidade em 
22

fixar nitrogênio no solo, controle de erosão e também por outros fatores benéficos inerentes à prática da adubação verde permanente neste tipo de cultura. Coleman (1995), cita também que, o amendoim forrageiro tem contribuído de forma significativamente economica na redução de plantas daninhas, patógenos, insetos, nematóides e no uso de fertilizantes nitrogenados, reduzindo o "input" no sistema de produção e, por se tratar de uma planta de porte rasteiro não interfere nas práticas culturais normais adotadas pelos citricultores.

No entanto, Coleman, (1995), lembra que existe a necessidade de experimentação, principalmente local, a fim de se verificar consistentemente os beneficios do amendoim forrageiro, como adubo verde perene, nos mais variados agroecossistemas, visando a otimização de sua utilização como uma prática agrícola que contribua positivamente na produção vegetal. 


\section{INTERAÇÕES COMPETITIVAS ENTRE ADUBAÇÃO VERDE E PLANTAS DANINHAS}

\section{Resumo}

Com o objetivo de avaliar os efeitos dos adubos verdes amendoim forrageiro (Arachis pintoi), crotalária (Crotalaria juncea L.) e feijāo guandu anão (Cajanus cajan L. Millsp.) sobre a infestação das plantas daninhas capim braquiária (Brachiaria decumbens Stapf.), capim colonião (Panicum maximum Jacq.), picão preto (Bidens pilosa L.) e infestação natural das plantas daninhas, na cultura do abacate (Persea americana Mill.) foi instalado um experimento de campo, na Escola Superior de Agricultura "Luiz de Queiroz", Universidade de São Paulo, Departamento de Produção Vegetal, Piracicaba-SP. O experimento foi conduzido nas entre linhas da cultura, em blocos casualizados, com parcelas subdivididas, quatro repetições e as parcelas principais foram constituídas dos adubos verdes e as subparcelas pela semeadura das plantas daninhas, além da infestação natural. A infestação das plantas daninhas foi avaliada através da contagem do número de plantas $/ \mathrm{m}^{2}$ e biomassa seca, e os adubos verdes através da biomassa seca produzida $/ \mathrm{m}^{2}$ Os resultados permitiram concluir que a utilização de adubos verdes na entrelinha da cultura do abacate contribui de maneira significativa na redução de populações de plantas daninhas auxiliando, de forma sustentável, no manejo integrado de 
plantas daninhas. As infestações de plantas daninhas são suprimidas de forma diferenciada pelos diferentes adubos verdes, sendo a crotalária, de maneira geral, mais efetiva na supressão das plantas daninhas. Para o amendoim forrageiro existe a necessidade de um controle das plantas daninhas no seu estabelecimento.

\section{COMPETITIVE INTERACTION BETWEEN COVER CROPS AND WEEDS}

\section{Summary}

With the objective of studying the effects of the cover crops Arachis pintoi, Crotalaria juncea and Cajanus cajan on the infestation of the weeds Brachiaria decumbens, Panicum maximum, Bidens pilosa and natural weed infestation, an experiment was installed in the experimental field of ESALQ - University of São Paulo - Department of Plant Production, Piracicaba - SP, Brazil. The experiment was conducted in the inter row of an avocado (Persea Americana Mill.) orchard, in randomized complete blocks design, with subplots, four replications and, the main plots were the cover crops and the sub plots were the weeds manually seeded in the plots besides one sub plot with the natural weed infestation of the area. The weed infestation was evaluated through counting of the number $/ \mathrm{m}^{2}$, and dry biomass, and the cover crop through dry biomass production $/ \mathrm{m}^{2}$. The results allowed the conclusion that growing cover crop in the inter row of an avocado orchard contribute significantly to reduce weed populations, being an auxiliary tool for the integrated weed management. The weed infestations are suppressed in different intensity, being Crotalaria juncea, in general, the most effective cover crop for the weed 
suppression. For the Arachis pintoi there is a need of controlling the weeds in the establishment of the cover crop.

\subsection{Introdução}

A produtividade econômica das culturas agrícolas é afetada de maneira direta ou indireta, por fatores ambientais, de natureza biótica ou abiótica. As plantas daninhas estão dentre os fatores bióticos e podem competir com as plantas cultivadas por água, nutrientes, luz, hospedar insetos, nematóides e outros organismos prejudiciais a estas plantas, bem como dificultar a adoção das práticas culturais, interferindo na qualidade do produto final (Gelmini, 1995).

Assim, as plantas daninhas constituem-se, num importante fator que afeta a economia agricola, ocasionando prejuizos nos cultivos e, quase sempre, aumentando o custo de produção. Devido a esses fatores e a importância econômica da abacaticultura, no Brasil, é necessário que o controle de plantas daninhas seja realizado de forma criteriosa, visando minimizar as interferências negativas causadas pelas plantas daninhas.

O abacateiro pertence à família Lauraceae, que engloba cerca de 150 espécies. Muito importante mundialmente, é originário da América Central (México, Antilhas, Guatemala): No México, ainda pode ser encontrado em estado silvestre. O abacate foi evoluindo a partir de individuos silvestres, por escolha e multiplicação dirigida, de fruta globosa e pequena como um limão, para as formas atuais. É considerado "legume" em boa parte do mundo, onde é consumido como salada, sopa e conservas (Meletti, 2000).

No Brasil, foi introduzido oficialmente em 1809, através de quatro mudas da variedade Antilhana levadas para o Jardim Botânico 
do Rio de Janeiro, de onde surgiu a variedade "Manteiga" que, foi a preferida pelos consumidores durante mais de cem anos (Meletti, 2000).

Atualmente, na cultura do abacate, o controle de plantas daninhas tem sido feito através de roçadeiras e cultivadores mecânicos, capina manual, gradeação e herbicidas (Donadio, 1995). Existem dados que mostram que a competição das plantas daninhas em pomares de abacateiros pode aumentar o consumo de água e fertilizantes em até 20\% (Suppo, 1982).

Considerando-se que as práticas culturais adotadas e utilizadas influem de maneira decisiva na dinâmica de populações de plantas daninhas, a prática de rotação de culturas, incluindo o uso de adubos verdes, traz benefícios no controle de plantas daninhas, além de outras vantagens técnicas, econômicas e ecológicas proporcionadas por este tipo de prática agricola.

Derpsch e Calegari (1993), definiram rotação de culturas, com sendo uma alternância regular e ordenada no cultivo de diferentes espécies vegetais, em seqüência temporal numa determinada área. Também, estes mesmos autores, além de outros, citam que a adubação verde é uma técnica fundamental para a recuperação de solos degradados, bem como, para conservar o solo (Igue, 1984; Vogtmann \& Wagner, 1987; Bulisani et al., 1987; Piamonte, 1996;).

Almeida e Rodrigues (1985), verificaram que há uma correlação linear entre a quantidade de fitomassa produzida por culturas de cobertura e a efetiva redução da infestação por plantas daninhas, modificando, inclusive, a composição floristica da área.

A presença da cobertura morta, pela sua ação alelopática, altera as caracteristicas físicas, químicas e biológicas do solo, interferindo no processo de dormềncia das sementes, germinação $\mathrm{e}$ desenvolvimento das plântulas (Almeida, 1991). 
Alguns citricultores, já substituem a cobertura morta vegetal de palha de capim, restos de culturas ou bagaço de cana, pelo cultivo nas entrelinhas com leguminosas ou gramineas (Kiss, 1997).

Experimento conduzido no Pará, utilizando crotalária (Crotalaria juncea) e guandu (Cajanus cajan), na cultura do milho, demonstrou que estas plantas controlaram a infestação de plantas daninhas. Por outro lado, a competição causada pelas leguminosas por água, nutrientes e luz, prejudicou o rendimento da cultura (Carvalho Brasil, 1992).

Fernandes et al. (1999), realizaram estudo com Crotalaria breviflora, Crotalaria spectabilis e Cajanus cajan para o controle de plantas infestantes e obtiveram respostas positivas e lineares de $C$. spectabilis e $C$. breviflora, na redução da densidade das plantas daninhas.

Em Pato Branco, estado do Paraná, pesquisa com leguminosas, incluindo Cajanus cajan, intercaladas com a cultura do milho, resultou em bom controle das plantas daninhas, variando conforme a espécie intercalada (Neto, 1993).

Estudos efetuados em Planaltina, DF, com o cultivo de milho sobre cobertura permanente de Arachis pintoi, mostrou bons resultados na supressão de plantas daninhas, com bom rendimento da cultura (Ayarza et al., 1998).

No Hawaii, pesquisa com Arachis pintoi como cobertura verde, na cultura do palmito, verificou que esta planta teve boa supressão no.controle de plantas infestantes e, depois de estabelecido, formou boa cobertura viva sobre o solo (Clement e DeFrank, 1998).

Desta forma, a adoção da prática da adubação verde, propicia uma série de benefícios e pode fazer parte, como uma valiosa ferramenta, de um sistema de manejo integrado de plantas daninhas. 
Assim, o presente trabalho teve como objetivo estudar o efeito das interações competitivas entre adubação verde e plantas daninhas, na cultura do abacate, através das avaliações de produção de biomassa seca das plantas daninhas e dos adubos verdes, bem como de densidade das plantas daninhas.

\subsection{Material e Métodos}

A pesquisa foi conduzida em área experimental do Departamento de Produção Vegetal da Escola Superior de Agricultura "Luiz de Queiroz", campus da USP/ESALQ, em Piracicaba - SP, cujo municipio apresenta as seguintes coordenadas geográficas: altitude de $560 \mathrm{~m}$, latitude de $22^{\circ}$ e $45^{\prime}$ Sul e longitude de 47॰ e $38^{\prime} \mathrm{W}$. O clima da região é o tipo Cwa, segundo a classificação de Koeppen, isto é, trata-se de clima mesotérmico, úmido, subtropical com inverno seco. De acordo com o Departamento de Ciências Exatas da USP/ESALQ, a temperatura média do mês mais quente está acima de $24^{\circ} \mathrm{C}$ e a do mês mais frio abaixo de $17^{\circ} \mathrm{C}$, apresentando uma precipitação pluvial média anual de $1200 \mathrm{~mm}$. Os dados pluviométricos e de temperatura encontram-se na Tabela 3.1.

Instalado em duas fases, a primeira durante a última semana de março e a outra na segunda quinzena de outubro de 1999, de forma intercalada em pomar jovem ("coleção" varietal de abacates Persea americana Mill.) do Departamento de Produção Vegetal da ESALQ, de aproximadamente quatro anos de idade, onde se pode encontrar plantas das variedades Antilhanas, Guatemalenses, Mexicanas e alguns híbridos, em solo cujas análises físicas e químicas podem ser observadas nas Tabelas 3.2 , e 3.3, respectivamente. 
Tabela 3.1. Dados pluviométricos e de temperatura mensais (durante os meses de condução de ensaio). Experimento de campo. Piracicaba, 2000 - USP/ESALQ.

\begin{tabular}{lcccccc}
\hline ANO & Mês & $\begin{array}{c}\text { Precipitação } \\
(\mathbf{m m})\end{array}$ & $\begin{array}{c}\text { UR } \\
\%\end{array}$ & $\begin{array}{c}\text { T. máxima } \\
\left({ }^{\circ} \mathbf{C}\right)\end{array}$ & $\begin{array}{c}\text { T. minima } \\
\left({ }^{\circ} \mathbf{C}\right)\end{array}$ & $\begin{array}{c}\text { T. Média } \\
(\cdot \mathbf{C})\end{array}$ \\
\hline 1999 & 03 & 210,8 & 81 & 31,4 & 19,0 & 25,2 \\
1999 & 04 & 89,0 & 81 & 28,5 & 15,3 & 21,8 \\
1999 & 05 & 51,3 & 79 & 25,4 & 11,2 & 18,9 \\
1999 & 06 & 68,6 & 83 & 23,9 & 11,0 & 17,5 \\
1999 & 07 & 2,7 & 77 & 26,4 & 12,0 & 19,2 \\
1999 & 08 & 0,0 & 64 & 27,9 & 10,2 & 19,1 \\
1999 & 09 & 85,9 & 70 & 28,8 & 14,0 & 21,4 \\
1999 & 10 & 28,5 & 73 & 28,5 & 15,4 & 21,9 \\
1999 & 11 & 52,1 & 72 & 29,5 & 15,7 & 22,6 \\
1999 & 12 & 269,9 & 78 & 30,6 & 19,0 & 24,8 \\
2000 & 01 & 235,9 & 83 & 30,2 & 19,1 & 24,7 \\
2000 & 02 & 124,0 & 87 & 29,9 & 19,2 & 24,6 \\
2000 & 03 & 185,3 & 84 & 29,7 & 18,5 & 24,1 \\
\hline
\end{tabular}

Fonte: Departamento de Ciências Exatas da USP/ESALQ.

Tabela 3.2. Análise física do solo onde foi instalado o experimento (Análise granulométrica). Experimento de campo. Piracicaba, 2000 - USP/ESALQ.

\begin{tabular}{cccccc}
\hline $\begin{array}{c}\text { Areia\% } \\
\text { Total }\end{array}$ & Silte \% & $\begin{array}{c}\text { Argila \% } \\
\text { Total }\end{array}$ & $\begin{array}{c}\text { Classe de } \\
\text { Textura }\end{array}$ & $\begin{array}{c}\text { DP } \\
\left(\mathbf{g} / \mathbf{c m}^{3}\right)\end{array}$ \\
\hline 43 & 19 & 38 & Argilosa & - & - \\
\hline
\end{tabular}

Análise feita pelo Departamento de Solos e Nutriçāo de Plantas da USP/ESALQ. 
Tabela 3.3. Análise química do solo onde foi instalado o experimento. Experimento de campo. Piracicaba, 2000 - USP/ESALQ.

\begin{tabular}{|c|c|c|c|c|c|c|c|c|c|}
\hline $\mathbf{p H}$ & m.o. & $\mathbf{P}$ & $\mathbf{K}$ & $\mathbf{C a}$ & $\mathbf{M g}$ & $\mathbf{H}+\mathbf{A l}$ & SB & $\mathbf{T}$ & $\mathbf{v}$ \\
\hline $\mathrm{CaCl}_{2}$ & $\mathbf{g} \mathbf{d m}^{-3}$ & $\mathbf{M g ~ d m}^{-3}$ & \multicolumn{6}{|c|}{ mmole dm-3 } & $\%$ \\
\hline 5,3 & 37 & 14 & 3,5 & 46 & 18 & 25 & 67,5 & 92,5 & 73 \\
\hline
\end{tabular}

Análise feita pelo Departamento de Solos e Nutrição de Plantas da USP/ESALQ.

Na primeira fase, o solo foi preparado, convencionalmente, nas entre linhas da cultura do abacate, cujo espaçamento é $10 \mathrm{~m} \mathrm{x}$ $10 \mathrm{~m}$, com uma roçada e uma gradagem leve e foi realizada a semeadura do adubo verde amendoim forrageiro (Arachis pintoi), com espaçamento de 0,5 m entre linhas e 12 sementes por metro linear. Essa operação foi realizada com semeadeira tratorizada.

$\mathrm{Na}$ segunda fase, o solo foi novamente preparado, de forma convencional, nas entrelinhas da cultura, com uma roçada e uma gradagem leve e foi realizada a semeadura dos adubos verdes crotalária e feijão guandu anão, cujas quantidades de sementes utilizadas foram, respectivamente, 25 e 20 sementes/m linear, com espaçamento de 0,5 $\mathrm{m}$ entre linhas. Essa operação, também, foi realizada com semeadeira tratorizada.

A semeadura das plantas daninhas, cujas sementes foram obtidas na empresa Shokucho do Brasil Agrícola Ltda., localizada no municipio de Engenheiro Coelho, estado de São Paulo, Brasil, após a devida pesagem em balança de precisão, foi feita a lanço. A seguir foi feita a incorporação superficial das sementes de plantas daninhas com uma grade leve, menos nas subparcelas em que estava o amendoim forrageiro, nas quais, nāo houve a incorporação. Foram utilizadas 16 gramas de sementes de capim braquiária, 16 gramas de sementes de 
capim colonião e 12,50 gramas de sementes de picão preto por subparcela de $16 \mathrm{~m}^{2}$. Desta maneira, quando foi instalada essa segunda fase do experimento, o amendoim forrageiro estava quase estabelecido no terreno, pois já havia, aproximadamente, seis meses que fora semeado. No entanto, nenhum tipo de manejo foi realizado durante esse período, isto é, da primeira para a segunda fase.

Nas linhas da cultura de abacate, o mato foi controlado uma única vez, através do método químico, usando-se o herbicida glyphosate aplicado com pulverizador costal, com solução a $1 \%$ do herbicida, e volume de calda de aproximadamente 300L/ha. É importante mencionar também que, até o final de todas as avaliaçōes, excetuandose a capina manual realizada, nas subparcelas, onde foram retiradas as amostras para avaliação da produção de biomassa seca dos adubos verdes, não houve nenhum outro tipo de intervenção na área.

Os adubos verdes utilizados foram o amendoim forrageiro (Arachis pintoi), crotalária (Crotalaria juncea L.), feijão guandu anão (Cajanus cajan (L.) Millsp.) e as plantas daninhas Brachiaria decumbens, Panicum maximum e Bidens pilosa L., mais a infestação natural do terreno, composta, na sua grande maioria, por dicotiledôneas.

$O$ delineamento experimental utilizado foi o de blocos casualizados com quatro repetições e com parcelas subdivididas, utilizando dois fatores de estudo, ou seja, adubos verdes e plantas daninhas, da seguinte forma: três adubos verdes, quatro plantas daninhas, num total de 48 subparcelas.

Cada subparcela constou de oito linhas de adubo verde com 0,5 $\mathrm{m}$ de largura e $4 \mathrm{~m}$ de comprimento, portanto uma área de $16,0 \mathrm{~m}^{2}$. Os parâmetros avaliados durante a condução do ensaio foram os seguintes: duas avaliações de contagem de infestação de plantas daninhas $/ \mathrm{m}^{2}$ e de produção de biomassa seca das plantas daninhas, realizadas, aos 30 e 60 dias após a instalação da segunda fase do 
experimento e uma avaliação da produção de biomassa seca dos adubos verdes, feita, também, 120 dias depois de encerrada a segunda fase do ensaio. As avaliações de produção de biomassa seca, tanto das plantas daninhas, como dos adubos verdes, foram expressas $\mathrm{em} \mathrm{g} / \mathrm{m}^{2}$.

Para obtenção das amostras, tanto de densidade quanto da biomassa das plantas daninhas e dos adubos verdes, utilizou-se um quadro de madeira de $0,5 \mathrm{~m}^{2}$, o qual era atirado duas vezes ao acaso nas subparcelas. Após contagem, a parte aérea, tanto das leguminosas como das plantas daninhas, era cuidadosamente cortada com uma tesoura, colocadas em sacos de papel devidamente etiquetados e levados ao laboratório para secagem em estufa à $50^{\circ} \mathrm{C}$ durante 48 horas e pesagem em balança de precisão.

Os dados obtidos foram analisados através da Análise de Variância, com o auxílio do Sistema de Análise Estatística - SANEST, sendo que as interações significativas tiveram suas médias comparadas entre si através do teste Tukey, ao nível de $5 \%$ de probabilidade.

\subsection{Resultados e Discussão}

Nas Tabelas 3.4 e 3.5, estão apresentadas as médias de densidade de plantas daninhas, ou seja, o número de plantas/ $\mathrm{m}^{2} \mathrm{da}$ primeira e segunda avaliação.

Analisando-se, em colunas, a Tabela 3.4, verifica-se que, para a planta daninha capim braquiária, o melhor controle foi obtido com a crotalária, seguida do feijão guandu anão e pelo amendoim forrageiro. Comparando-se com a testemunha, a crotalária reduziu a infestação dessa planta daninha em $94,2 \%$, o guandu anão em $72,7 \%$ e o amendoim forrageiro em $30,7 \%$, havendo diferença significativa entre as médias dos três tratamentos. 
Tabela 3.4. Médias de densidade de plantas daninhas (plantas $/ \mathrm{m}^{2}$ ) $-1^{\text {a }}$ avaliação realizada aos 30 dias após instalação do experimento. Experimento de campo. Piracicaba, 2000 USP/ESALQ.

\begin{tabular}{lcccc}
\hline \multirow{2}{*}{ Adubos verdes1 } & \multicolumn{4}{c}{ Plantas daninhas (plantas/m²) } \\
\cline { 2 - 5 } & $\begin{array}{l}\text { Brachiaria } \\
\text { decumbens }\end{array}$ & $\begin{array}{c}\text { Panicum } \\
\text { maximum }\end{array}$ & $\begin{array}{l}\text { Bicaens } \\
\text { pilosa }\end{array}$ & $\begin{array}{c}\text { Infestaçäo } \\
\text { natural }\end{array}$ \\
\hline Arachis pintoi & $28,5 \mathrm{a}^{2} \mathrm{~A}$ & $16,9 \mathrm{~b} \mathrm{~B}$ & $5,5 \mathrm{bC}$ & $18,0 \mathrm{bB}$ \\
Crotalaria juncea & $2,3 \mathrm{cAB}$ & $6,6 \mathrm{cA}$ & $1,9 \mathrm{bB}$ & $5,3 \mathrm{cAB}$ \\
Cajanus cajan & $11,2 \mathrm{bA}$ & $2,5 \mathrm{cB}$ & $4,9 \mathrm{bB}$ & $13,6 \mathrm{bA}$ \\
Testemunha (s/capina) & $41,2 \mathrm{aC}$ & $71,7 \mathrm{aB}$ & $32,4 \mathrm{aC}$ & $129,4 \mathrm{aA}$ \\
\hline Cv parcela $=14,77 \%$ & $\mathrm{Cv}$ sub parcela $=13,10 \%$ & & \\
DMS $(1)=1,09$ & $\mathrm{DMS}(2)=1,06$ & & & \\
\hline
\end{tabular}

1Para análise estatistica os dados foram transformados segundo $\sqrt{\mathrm{x}+0,5}$;

${ }^{2}$ Médias seguidas por letras distintas maiúsculas na linha e minúsculas na coluna diferem entre si a 5\% de significância pelo teste de Tukey.

Em relação à planta daninha capim colonião, observa-se que os melhores controles foram obtidos pelo guandu anão, seguido pela crotalária e pelo amendoim forrageiro. Em comparação com a testemunha, o guandu anão reduziu a infestação de capim colonião em $96,5 \%$, a crotalária em $90,7 \%$ e o amendoim forrageiro em $76,3 \%$. Neste caso, as médias dos tratamentos com crotalária e guandu anão não diferiram estatisticamente entre si.

Os três adubos verdes suprimiram com eficiência o picão preto, com uma pequena superioridade da crotalária. Quando comparada com a testemunha, observa-se que a crotalâria reduziu a infestação de picão preto em 94,0\%, o guandu anão em $84,7 \%$ e o amendoim forrageiro em $82,7 \%$. No entanto, nāo houve diferença significativa entre as médias dos três tratamentos. 
O melhor controle da infestação natural foi obtido também pela crotalária, seguida pelo guandu anão e pelo amendoim forrageiro. Em comparação com a testemunha, a crotalária reduziu a densidade da infestação natural em 95,9\%, o guandu anāo em 89,4\% e o amendoim forrageiro em $86,0 \%$, nāo havendo diferença significativa entre as médias dos tratamentos com guandu anão e amendoim forrageiro.

Ainda na Tabela 3.4, agora sendo analisada nas linhas, pode-se notar que o amendoim forrageiro foi mais eficiente na supressão da infestação de picão preto, seguido pelo capim colonião, infestação natural e capim braquiária. A crotalária teve maior eficiência na supressão de picão preto, seguido pelo capim braquiária, infestação natural e capim colonião e o feijão guandu anão foi mais eficiente no controle do capim colonião, seguido pelo picão preto, capim braquiária e infestação natural.

A análise, em colunas, da Tabela 3.5, da segunda avaliação das médias de densidade de plantas daninhas $/ \mathrm{m}^{2}$, indica que, para a planta daninha capim braquiária, a melhor supressão foi obtida com a crotalária, seguida do feijāo guandu anão e amendoim forrageiro, cujo tratamento não diferiu, estatisticamente, da testemunha. Comparandose com a testemunha, a crotalária reduziu a infestação dessa planta daninha em $90,0 \%$, o guandu anão em $65,7 \%$ e o amendoim forrageiro em $7,4 \%$, havendo diferença significativa entre as médias dos três tratamentos.

Em relação à planta daninha capim colonião, observa-se que os melhores controles foram realizados pelo guandu anão, seguido pela crotalária e pelo amendoim forrageiro. Em comparação com a testemunha, o guandu anão reduziu a infestação de capim colonião em $94,9 \%$, a crotalária em $94,0 \%$ e o amendoim forrageiro em $73,9 \%$. Neste caso, não houve diferença significativa, entre as médias dos tratamentos com guandu anão e crotalária. 
Os três adubos verdes suprimiram com eficiência o picão preto, com uma pequena vantagem da crotalária. Quando comparada com a testemunha, observa-se que a crotalária reduziu a infestação de picão preto em 90,8\%, o guandu anão em $88,3 \%$ e o amendoim forrageiro em $84,8 \%$. No entanto, não houve diferença estatística. significativa entre as médias dos três tratamentos.

$\mathrm{Na}$ infestação natural, observa-se que a melhor supressāo foi obtida pela crotalária, seguida pelo guandu anāo e pelo amendoim forrageiro. Comparando-se com a testemunha, a crotalária reduziu a densidade da infestação natural em 95,7\%, o guandu anão em 89,3\% e o amendoim forrageiro em $84,9 \%$, sendo que não houve diferença significativa entre as médias dos tratamentos com guandu anão e amendoim forrageiro.

Analisando-se a Tabela 3.5, em linhas, verifica-se que o amendoim forrageiro suprimiu com mais eficiência o picão preto, depois o capim colonião, infestação natural e capim braquiária; a crotalária foi mais eficiente no controle da infestação de picão preto, seguida pelo capim braquiária, capim colonião e infestação natural. Entretanto, não houve diferença significativa entre essas duas médias. E, o feijão guandu anão teve maior supressão na infestação de capim colonião, seguido pelo picão preto, capim braquiária e infestação natural.

Nas Tabelas 3.6 e 3.7, estão apresentadas as médias de produção de biomassa seca de plantas daninhas, em $\mathrm{g} / \mathrm{m}^{2}$, da primeira e da segunda avaliação.

Analisando-se, em colunas, a Tabela 3.6, verifica-se, em relação ao capim braquiária, que houve uma menor produção de biomassa seca nos tratamentos com crotalária, seguidos por guandu anão e amendoim forrageiro. Comparada com a testemunha, a crotalária reduziu em $94,2 \%$ a produção de biomassa seca dessa planta daninha, o guandu anão em $87,5 \%$ e o amendoim forrageiro em $38,0 \%$, sendo 
que, não se observou diferença significativa entre as médias dos tratamentos com crotalária e guandu anão.

Em relação ao capim coloniāo, o melhor resultado foi obtido pelo guandu anão, que reduziu em $98,2 \%$ a produção de biomassa seca dessa planta daninha. Crotalária e amendoim forrageiro reduziram a produção de biomassa seca de capim colonião em 92,3\% e 84,8\%, respectivamente, sendo que as médias entre estes dois tratamentos não apresentaram diferenças significativas.

Tabela 3.5. Médias de densidade de plantas daninhas (plantas $/ \mathrm{m}^{2}$ ) $-2^{\text {a }}$ avaliação realizada aos 60 dias após instalação do experimento. Experimento de campo. Piracicaba, 2000 USP/ESALQ.

Plantas daninhas (plantas $/ \mathrm{m}^{2}$ )

\begin{tabular}{lcccc} 
Adubos verdes & $\begin{array}{c}\text { Brachiaria } \\
\text { decumbens }\end{array}$ & $\begin{array}{c}\text { Panicum } \\
\text { maximum }\end{array}$ & $\begin{array}{c}\text { Bidens } \\
\text { pilosa }\end{array}$ & $\begin{array}{c}\text { Infestação } \\
\text { natural }\end{array}$ \\
\hline Arachis pintoi & $33,5 \mathrm{a}^{2} \mathrm{~A}$ & $18,8 \mathrm{bB}$ & $5,6 \mathrm{bC}$ & $19,6 \mathrm{bB}$ \\
Crotalaria juncea & $3,6 \mathrm{cA}$ & $4,3 \mathrm{cA}$ & $3,4 \mathrm{bA}$ & $5,5 \mathrm{cA}$ \\
Cajanus cajan & $12,4 \mathrm{bA}$ & $3,6 \mathrm{cB}$ & $4,3 \mathrm{bB}$ & $13,8 \mathrm{bA}$ \\
Testemunha (s/capina) & $36,3 \mathrm{aC}$ & $72,2 \mathrm{aB}$ & $37,3 \mathrm{aC}$ & $130,4 \mathrm{aA}$ \\
\hline $\mathrm{Cv}$ parcela $=13,08 \%]$ & $\mathrm{Cv}$ sub parcela $=13,92 \%$ & & \\
DMS(1) $=1,12$ & $\mathrm{DMS}(2)=1,15$ & & \\
\hline
\end{tabular}

1 Para análise estatistica os dados foram transformados segundo $\sqrt{\mathrm{x}+0,5}$;

2Médias seguidas por letras distintas maiúsculas na linha e minúsculas na coluna diferem entre si a 5\% de significância pelo teste de Tukey. 
Tabela 3.6. Médias de produçāo de biomassa seca de plantas daninhas $\left(\mathrm{g} / \mathrm{m}^{2}\right)-1^{\mathrm{a}}$ avaliação realizada 30 dias após a instalação do experimento. Experimento de campo. Piracicaba, 2000 USP/ESALQ.

\begin{tabular}{lcccc}
\hline \multirow{2}{*}{ Adubos verdes } & \multicolumn{4}{c}{ Plantas daninhas (g/m²) } \\
\cline { 2 - 5 } & $\begin{array}{l}\text { Brachiaria } \\
\text { decumbens }\end{array}$ & $\begin{array}{c}\text { Panicum } \\
\text { maximum }\end{array}$ & $\begin{array}{c}\text { Bidens } \\
\text { pilosa }\end{array}$ & $\begin{array}{c}\text { Infestação } \\
\text { natural }\end{array}$ \\
\hline Arachis pintoi & $\mathbf{1 1 1 , 6 \mathrm { b } ^ { 2 } \mathrm { A }}$ & $40,8 \mathrm{bB}$ & $29,2 \mathrm{bB}$ & $101,5 \mathrm{bA}$ \\
Crotalaria juncea & $10,2 \mathrm{cA}$ & $20,7 \mathrm{bA}$ & $8,0 \mathrm{cA}$ & $13,4 \mathrm{dA}$ \\
Cajanus cajan & $22.4 \mathrm{cA}$ & $4,7 \mathrm{cB}$ & $16,7 \mathrm{bcAB}$ & $32,1 \mathrm{cA}$ \\
Testemunha & $180,2 \mathrm{aB}$ & $270,4 \mathrm{aA}$ & $65,3 \mathrm{aC}$ & $244,7 \mathrm{aA}$ \\
\hline Cv parcela $=13,74 \%$ & $\mathrm{Cv}$ sub parcela $=13,57 \%$ & & \\
DMS(1) $=1,89$ & $\mathrm{DMS}(2)=1,90$ & & \\
\hline
\end{tabular}

1 Para análise estatística os dados foram transformados segundo $\sqrt{\mathrm{x}+0,5}$;

${ }^{2}$ Médias seguidas por letras distintas maiúsculas na linha e minúsculas na coluna diferem entre si a $5 \%$ de significancia pelo teste de Tukey.

Tabela 3.7. Médias de produção de biomassa seca de plantas daninhas $\left(\mathrm{g} / \mathrm{m}^{2}\right)-2^{\mathrm{a}}$ avaliação realizada 60 dias após a instalação do experimento. Experimento de campo. Piracicaba, 2000 USP/ESALQ.

Plantas daninhas $\left(\mathrm{g} / \mathrm{m}^{2}\right)$

\begin{tabular}{lcccc} 
Adubos verdes & $\begin{array}{c}\text { Brachiaria } \\
\text { decumbens }\end{array}$ & $\begin{array}{c}\text { Panicum } \\
\text { maximum }\end{array}$ & $\begin{array}{c}\text { Bidens } \\
\text { Pilosa }\end{array}$ & $\begin{array}{c}\text { Infestação } \\
\text { natural }\end{array}$ \\
\hline Arachis pintoi & $122,5 \mathrm{a}^{2} \mathrm{~A}$ & $42,9 \mathrm{bB}$ & $35,5 \mathrm{bB}$ & $91,8 \mathrm{bA}$ \\
Crotalaria juncea & $12,1 \mathrm{cA}$ & $17,7 \mathrm{bcA}$ & $14,1 \mathrm{bA}$ & $19,9 \mathrm{cA}$ \\
Cajanus cajan & $39,7 \mathrm{bA}$ & $10,6 \mathrm{cB}$ & $13,2 \mathrm{bB}$ & $29,0 \mathrm{cAB}$ \\
Testemunha & $139,5 \mathrm{aB}$ & $264,7 \mathrm{aA}$ & $103,5 \mathrm{aB}$ & $288,8 \mathrm{aA}$ \\
\hline Cv parcela = 17,69\% & $\mathrm{Cv}-\mathrm{sub}$ parcela $=16,78 \%$ & & \\
DMS(1) = 2,48 & $\mathrm{DMS}(2)=2,47$ & & \\
\hline
\end{tabular}

1Para análise estatistica os dados foram transformados segundo $\sqrt{\mathrm{x}+0,5}$;

${ }^{2}$ Médias seguidas por letras distintas maiúsculas na linha e minúsculas na coluna diferem entre si a $5 \%$ de significância pelo teste de Tukey. 
A produção de biomassa seca de picão preto foi mais reduzida, em comparação com a testemunha, pela crotalária em 87,7\% e, em seguida pelo guandu anão e amendoim forrageiro, com redução de $74,4 \%$ e 55,3\%, respectivamente. No entanto, não se observou diferença significativa entre as médias dos tratamentos com crotalária e guandu anão e destas com a média dos tratamentos com amendoim forrageiro.

A crotalária mostrou maior eficiência para redução da biomassa seca da infestação natural, diminuindo em $94,4 \%$ a produção de biomassa seca destas plantas daninhas, quando comparada com a testemunha, enquanto que guandu anão reduziu em $86,8 \%$ e amendoim forrageiro em 58,5\%. Nesse caso, todos os tratamentos apresentaram diferenças significativas entre as suas médias.

Analisando-se a Tabela 3.6, em linhas, observa-se que o amendoim forrageiro reduziu, com mais eficiência, a produção de biomassa seca do picão preto, capim colonião, infestação natural e capim braquiária, sendo que não se notou diferença significativa entre as médias desses últimos dois tratamentos; a crotalária reduziu com mais eficiência a produção de biomassa seca de picão preto, seguida por capim braquiária, infestação natural e capim colonião. Entretanto, não se observou diferenças significativas entre as médias dos tratamentos. E, o feijão guandu anão, foi mais efetivo na redução da produção de biomassa seca de capim colonião, seguido por picão preto e capim braquiária e infestação natural, sendo que não se notou diferenças significativas entre as médias dos tratamentos com capim colonião e picão preto.

Analisando-se, em colunas, a Tabela 3.7, a segunda avaliação das médias de produção de biomassa seca de plantas daninhas, em $\mathrm{g} / \mathrm{m}^{2}$, pode-se notar que, em relação ao capim braquiária, observou-se uma menor produção de biomassa seca nos tratamentos com crotalária, seguidos por guandu anão e amendoim forrageiro. Em 
comparação com a testemunha, a crotalária reduziu em 91,3\% a produção de biomassa seca dessa planta daninha, o guandu anão em $71,5 \%$ e o amendoim forrageiro em $12,1 \%$, sendo que, entre todas as médias dos tratamentos se observou diferença significativa. $O$ melhor resultado para o capim colonião foi obtido pelo guandu anão, que reduziu, quando comparado com a testemunha, em 95,9\% a produção de biomassa seca dessa planta daninha, enquanto que crotalária e amendoim forrageiro, reduziram em 93,3\% e 83,7\%, respectivamente, sendo que as médias entre os tratamentos com crotalária e amendoim forrageiro não tiveram diferença significativa, assim como as médias entre os tratamentos com crotalária e guandu anão.

A produção de biomassa seca de picão preto foi mais reduzida, em comparação com a testemunha, pelo guandu anão, em $87,2 \%$, pela crotalária em $86,3 \%$ e pelo amendoim forrageiro em $65,6 \%$, sendo que esses três tratamentos não apresentaram diferenças significativas entre suas médias. Em relação a redução da produção de biomassa seca da infestação natural, a crotalária mostrou maior eficiência, reduzindo em $93,0 \%$ a produção de biomassa seca destas plantas daninhas, quando comparada com a testemunha, enquanto que guandu anão reduziu em $89,9 \%$ e o amendoim forrageiro em $68,2 \%$, sendo que, não se notou diferenças significativas entre as médias dos. tratamentos com crotalária e guandu anão.

Observando-se a Tabela 3.7, em linhas, verifica-se que o amendoim forrageiro reduziu, com mais eficiência, a produção de biomassa seca do picão preto, capim colonião, infestação natural e capim braquiária, sendo que não se notou diferença significativa entre as médias dos dois primeiros tratamentos, e nem entre as médias desses últimos dois tratamentos; a crotalária foi mais eficiente na redução da produção de biomassa seca de capim braquiária, seguida por picão preto, capim colonião e infestação natural. No entanto, não se 
notou diferenças significativas entre as médias dos tratamentos. $\mathrm{E}$, o feijão guandu anão, mostrou melhor resultado na redução da produção de biomassa seca de capim colonião, seguido por picão preto, infestação natural e capim braquiária, sendo que apenas as médias dos tratamentos com capim braquiária apresentaram diferenças significativas, quando comparadas com as médias dos demais tratamentos.

$\mathrm{Na}$ tabela 3.8, estão apresentadas as médias de produção de biomassa seca dos adubos verdes $\left(\mathrm{em} \mathrm{g} / \mathrm{m}^{2}\right)$.

Analisando-se a Tabela 3.8, em colunas, pode-se observar que em relação ao amendoim forrageiro, o capim braquiária foi o que mais reduziu, em comparação com a testemunha, a produção de biomassa seca desse adubo verde $(67,6 \%)$, seguida pela infestação natural $(44,5 \%)$, capim colonião $(42,3 \%)$ e picão preto $(28,5 \%)$, sendo que apenas as médias do tratamentos com capim braquiária diferiram estatisticamente das médias dos demais tratamentos. A redução da produção de biomassa seca da crotalária, foi maior no tratamento com capim colonião, seguida pela infestação natural, picão preto e capim braquiária. Em comparação com a testemunha, o capim colonião reduziu, a produção de biomassa seca deste adubo verde, em 51,9\%, a infestação natural em 23,7\%, o picão preto em $14,9 \%$ e o capim braquiária em 14,6\%. Nesse caso, somente as médias dos tratamentos com capim coloniāo apresentaram diferenças significativas, quando comparadas com as médias dos outros tratamentos. No que diz respeito a produção de biomassa seca de feijão guandu anão, em comparação com a testemunha, a maior redução foi efetuada pelo picão preto $(50,3 \%)$, seguida pela infestação natural $(35,5 \%)$, capim colonião $(14,0 \%)$ e capim braquiária $(10,7 \%)$. Somente as médias dos tratamentos com picão preto apresentaram diferenças significativas quando comparadas com as médias dos outros tratamentos. 
Tabela 3.8. Médias de produção de biomassa seca dos adubos verdes $\left(\mathrm{g} / \mathrm{m}^{2}\right)$ aos 120 dias após a instalação do experimento. Experimento de campo. Piracicaba, 2000 - USP/ESALQ.

\begin{tabular}{lccc}
\hline Tratamentos & \multicolumn{3}{c}{ MS Adubos verdes $\left(\mathbf{g} / \mathbf{m}^{2}\right)$} \\
\cline { 2 - 4 } (Plantas daninhas) & $\begin{array}{c}\text { Arachis } \\
\text { pintoi }\end{array}$ & $\begin{array}{c}\text { Crotalaria } \\
\text { juncea }\end{array}$ & $\begin{array}{c}\text { Cajanus } \\
\text { cajan }\end{array}$ \\
\hline Brachiaria decumbens & $83,8 \mathrm{~b}^{2} \mathrm{C}$ & $675,4 \mathrm{abA}$ & $354,1 \mathrm{Ab}$ \\
Panicum maximum & $149,6 \mathrm{abB}$ & $411,1 \mathrm{cA}$ & $341,0 \mathrm{abA}$ \\
Bidens pilosa & $185,3 \mathrm{abB}$ & $672,4 \mathrm{abA}$ & $196,8 \mathrm{bB}$ \\
Inf. Natural & $143,9 \mathrm{abB}$ & $603,1 \mathrm{bA}$ & $255,6 \mathrm{abB}$ \\
Testemunha & $259,4 \mathrm{aC}$ & $790,8 \mathrm{aA}$ & $396,6 \mathrm{aB}$ \\
\hline Cv parcela $=20,83 \%$ & $\mathrm{Cv} \mathrm{sub} \mathrm{parcela}=19,69 \%$ & \\
DMS $(1)=85,04$ & $\mathrm{DMS}(2)=147,30$ & \\
\hline
\end{tabular}

${ }_{1}^{1}$ Para análise estatistica os dados foram transformados segundo $\sqrt{x+0,5}$;

2Médias seguidas por letras distintas maiúsculas na linha e minúsculas na coluna diferem entre si a 5\% de significância pelo teste de Tukey.

Fazendo-se a análise da Tabela 3.8, em linhas, observa-se que, no tratamento com capim braquiária, a maior produção de biomassa seca foi da crotalária, seguida pelo guandu anão e amendoim forrageiro, sendo que, as médias de produção de biomassa seca dos três tratamentos apresentaram diferenças significativas, quando comparadas entre si. O tratamento com capim colonião propiciou um melhor resultado na produção de biomassa seca da crotalária, seguida por guandu anão e amendoim forrageiro. Entretanto, as médias de produção de biomassa seca do amendoim forrageiro apresentaram diferenças significativas quando comparadas com as médias de produção de biomassa seca dos outros dois adubos verdes. No tratamento com picão preto, pode-se verificar que, a maior produção de biomassa seca foi da 
crotalária, seguida por guandu anão e amendoim forrageiro, sendo que as médias de produção de biomassa seca da crotalária, diferiram estatisticamente das outras duas. E, na infestação natural, a maior produção de biomassa seca foi da crotalária, seguida por guandu anão e amendoim forrageiro. Também, nessa situação, as médias de produção de biomassa seca da crotalária diferiram, estatisticamente, das demais.

\subsection{Conclusões}

a) A Crotalaria juncea é o adubo verde que demonstra, de forma geral, maior eficiência na supressão de todas as plantas daninhas em estudo.

b) O Cajanus cajan reduz com mais eficiência do que a Crotalaria juncea, a infestação da planta daninha Panicum maximum, seguido por Bidens pilosa, Brachiaria decumbens e infestação natural. Quando comparado com Arachis pintoi, o Cajanus cajan é mais efetivo no controle de Bidens pilosa, infestação natural e Brachiaria decumbens.

c) O adubo verde perene, Arachis pintoi, comparado entre si, é mais eficiente na redução da infestação de Bidens pilosa, seguido por Panicum maximum infestação natural e Brachiaria decumbens.

d) Em ordem decrescente, as plantas daninhas em estudo, Brachiaria decumbens, Panicum maximum, Bidens pilosa e infestação natural interferem mais fortemente na produção de biomassa seca do Arachis pintoi, Cajanus cajan e Crotalaria juncea. 
e) As três leguminosas em estudo reduziram, significativamente, a infestação das plantas daninhas testadas nas entre linhas da cultura do abacate em formação.

f) As plantas daninhas monocotiledôneas causam maior interferência negativa nas culturas, quando comparadas com as dicotiledôneas.

g) A Crotalaria juncea é o adubo verde que, de maneira geral, foi menos prejudicado pelas interferências negativas das plantas daninhas em estudo, seguida pelo Cajanus cajan e pelo Arachis pintoi.

h) A utilização com sucesso do adubo verde Arachis pintoi necessita de um manejo de plantas daninhas no estabelecimento da cultura, independente da época de plantio.

i) A utilização de adubação verde contribui de maneira significativa na redução de populações de plantas infestantes, auxiliando, de forma sustentável, no manejo integrado de plantas daninhas, além de contribuir com outros beneficios inerentes a utilização desta prática agricola. 
ANEXO 
Tabela 3.9. Resumo do Quadro de Análise de Variância das avaliaçōes de densidade e biomassa seca das plantas daninhas. Experimento de campo. Piracicaba, 2000 - USP/ESALQ.

\begin{tabular}{llllll}
\hline & & \multicolumn{4}{c}{ Quadrados médios (Prob. > F) } \\
\cline { 3 - 6 } CV & GL & DI & DII & MSI & MSII \\
\hline Adubo verde & 3 & $112,0409(0,0000)$ & $109,5183(0,0000)$ & $324,9956(0,0000)$ & $321,8954(0,0000)$ \\
Bloco & 3 & $0,3806(0,5475)$ & $0,6269(0,1946)$ & $1,1361(0,3953)$ & $2,8405(0,2746)$ \\
Residuo(A) & 9 & 0,3948 & 0,3245 & 1,0227 & 1,8689 \\
P.D. & 3 & $15,9490(0,0000)$ & $14,6472(0,0000)$ & $39,8489(0,0000)$ & $291297(0,0000)$ \\
Adu.* P.D & 9 & $6,7849(0,0000)$ & $7,4035(0,0000)$ & $18,1215(0,0000)$ & $15,9184(0,0000)$ \\
Residuo (B) & 36 & 0,3107 & 0,3677 & 0,9987 & 1,6817 \\
\hline
\end{tabular}

Tabela 3:10. Resumo do Quadro da Análise de Variância da avaliação de biomassa seca dos adubos verdes. Experimento de campo. Piracicaba, 2000 - USP/ESALQ.

\begin{tabular}{lcc}
\hline CV & GL & $\begin{array}{c}\text { Quadrados médios (Prob }>\text { F) } \\
\text { MS (Adubo verde) }\end{array}$ \\
\hline Adubo verde & 2 & $1139794,7823(0,0008)$ \\
Bloco & 3 & $1145,6533(0,8957)$ \\
Resíduo (A) & 6 & 5876,7824 \\
P.D & 4 & $57107,1654(0,0000)$ \\
Ad. ${ }^{*}$ P.D & 8 & $32015,4986(0,0001)$ \\
Resíduo (B) & 36 & 5254,7400 \\
\hline
\end{tabular}




\section{EFEITOS DE ADUBOS VERDES NO RECRUTAMENTO DO BANCO DE SEMENTES DE PLANTAS DANINHAS}

\section{Resumo}

Com o objetivo de estudar o efeito da adubação verde sobre o banco de sementes de plantas daninhas através de amostragens de solo feita em áreas cultivadas com adubos verdes, foi desenvolvido um ensaio em casa-de-vegetação do Departamento de Produção Vegetal da USP/ESALQ-Piracicaba-SP. As parcelas experimentais foram conduzidas em bandejas de $30 \mathrm{~cm} \times 20 \mathrm{~cm} \times 5 \mathrm{~cm}$, com $1 \mathrm{Kg}$ de solo, amostrado por um trado de $4,3 \mathrm{~cm}$ de diâmetro, a partir de parcelas experimentais existentes no campo. O delineamento experimental foi no esquema fatorial com três adubos verdes (Arachis pintoi, Crotalaria juncea e Cajanus cajan), e quatro plantas daninhas (Brachiaria decumbes, Panicum maximum, Bidens pilosa, além da infestação natural). Os dados coletados para a análise foram o número de plantas emergidas aos 30 e 60 dias após a instalação do experimento. Os resultados permitiram concluir que a Crotalaria juncea foi o adubo verde mais eficiente na redução da emergência das plantas daninhas estudadas no experimento. De uma forma geral, todos os adubos verdes afetaram de forma significativa o recrutamento do banco de sementes de plantas daninhas, quando comparado com áreas sem a utilizaçāo da 
prática da adubação verde, constituindo, portanto, em uma prática que pode fazer parte do manejo integrado de plantas daninhas.

\section{EFFECTS OF COVER CROPS ON THE WEED SEEDBANK RECRUITMENT}

\section{Summary}

In order to study the effect of green manure on soil seedbank through soil samples from areas grown with legumes cover crops, it was developed a greenhouse assay in the Department of Plant Production of USP/ESALQ - Piracicaba - SP, Brazil. The experimental plots were conducted in aluminum trays of $30 \mathrm{~cm} \times 20 \mathrm{~cm} \times 5 \mathrm{~cm}$, using $1.0 \mathrm{~kg}$ of soil, sampled with a soil sampler core of $4.3 \mathrm{~cm}$ diameter, from an experimental area installed in field conditions. The experimental design was a factorial with three green manure (Arachis pintoi, Crotalaria juncea and Cajanus cajan), and four weeds (Brachiaria decumbens, Panicum maximum, Bidens pilosa, and natural weed infestation). The data collected were the number of weeds emerged at 30 and 60 days after experiment installation. The results allowed the conclusion that Crotalaria juncea was the most efficient legume cover crop in reducing the weed emergence. All green manure species grown in the experiment affected significantly the soil seedbank recruitment, when compared to areas without the use of this practice, being an important tool, that could be included in the integrated weed management. 


\subsection{Introdução}

O banco de sementes de um solo pode ser entendido como sendo a reserva de sementes e propágulos vegetativos em profundidade e na superficie do solo (Roberts, 1981). Segundo Fernández-Quintanilla et al. (1991), esta reserva constitui-se a origem do ciclo de vida das espécies vegetais. Por outro lado, ela é também, um arquivo de informações das condições ambientais e práticas culturais passadas, sendo um fator importante de avaliação do potencial de infestação da comunidade infestante no presente e futuro (Templeton \& Levin, 1979).

O banco de sementes do solo é utilizado para estudar as relações quantitativas entre a sua população e a da flora infestante (Dessaint et al., 1990). Essas informações permitem elaborar indices de predição e modelos de emergência, permitindo a previsão de futuras infestações e definição de medidas adequadas de manejo (Barralis \& Chadoeuf, 1987; Fernández-Quintanilla, 1988).

A composição e densidade do banco de sementes sofrem grandes variações, tendo relação direta com o histórico da área e com o sistema de produção adotado. O sistema de preparo de solo afeta diretamente a produção de sementes de planta daninha na área, bem como o distúrbio causado no solo determina a distribuição vertical quantitativa do banco de sementes. Desta forma, a densidade da população de plantas daninhas na área é afetada diretamente pelas práticas culturais (Buhler, 1995).

Estudos da influência do tipo de preparo de solo sobre o banco de sementes indicam que mais de $70 \%$ das sementes se encontram na camada de $0-5 \mathrm{~cm}$, para parcelas sem preparo, e $33 \%$ 
para locais onde foi feita escarificação superficial do solo (Clements et al., 1996; Cardina \& Sparrow, 1996).

O revolvimento do solo estimula a germinação das sementes por expô-las à luz e por possibilitar uma maior temperatura e umidade. Entretanto, o efeito das práticas de preparo de solo sobre a quebra de dormência das sementes é função também da distribuição vertical das sementes no perfil, antes e depois do cultivo (Cavers \& Benoit, 1989).

A dormência de sementes é o fenômeno pelo qual sementes de uma determinada espécie, mesmo sendo viáveis e tendo todas as condições ambientais favoráveis, deixam de germinar (Carvalho \& Nakagawa, 1983). Sementes não dormentes germinam com facilidade em condições ideais de umidade, temperatura e oxigênio. Quando não há germinação ou quando esta ocorre com dificuldade, mesmo favorecida por fatores ambientais, elas são ditas dormentes (Côme, 1982). A dormência é a principal causa da sobrevivência das sementes de plantas daninhas no solo, causando infestações prolongadas nas aéreas de cultivo, distribuindo a germinação ao longo do tempo (Chadoeuf-Hannel, 1985). A dinâmica de um banco de sementes é influenciada diretamente pela sucessão de eventos de entrada e saída de sementes do banco em relação ao tempo (Simpson et al., 1989) e determina em que densidade será encontrada uma espécie na comunidade, tanto como reservas de sementes, quanto como plantas, mesmo que a correlação entre essas duas seja baixa (Rice, 1989).

As composiçōes, tamanho do banco de sementes e vegetação presente na superficie do solo são indicadores de toḍo o sistema de manejo de solo e plantas daninhas, que foi realizado.

A rotação de culturas se apresenta como uma prática eficiente no controle de plantas daninhas por diversificar a pressāo de seleção, alterando os padrões de distúrbios. Buhler et al., (1997), citam que a rotação de culturas reduz o tamanho do banco, pois a seqüência 
de cultivos, propicia diferentes modelos de competição, alelopatia, distúrbios do solo em cada uma das culturas seqüenciadas, reduzindo assim a pressão de seleção para plantas daninhas especificas. Em sistemas de rotação, quando comparado com monocultivo, foi encontrado menor quantidade de sementes no solo (Ball \& Miller, 1990; Schreiber, 1992).

Nos agroecossistemas, a redução do tamanho do banco de sementes, através de estratégias de manejo, tem sido objeto de pesquisas, que possam contribuir nos sistemas de manejo integrado de plantas daninhas. A rotação de culturas e utilização de adubação verde é, sem dúvida, uma destas estratégias.

Assim, o presente trabalho tem como objetivo estudar o efeito da utilização da adubação verde no recrutamento do banco de sementes, através das avaliações de densidade das plantas daninhas, que germinam em solos provenientes de área cultivada com os adubos verdes amendoim forrageiro (Arachis pintoi), crotalária (Crotalaria juncea) e feijão guandu anão (Cajanus cajan).

\subsection{Material e Métodos}

O ensaio foi conduzido em casa-de-vegetação da área experimental do Departamento de Produção Vegetal da Escola Superior de Agricultura "Luiz de Queiroz", campus da USP/ESALQ, em Piracicaba - SP, cujo município apresenta as seguintes coordenadas geográficas: altitude de $560 \mathrm{~m}$, latitude de $22^{\circ}$ e $45^{\prime}$ Sul e longitude de $47^{\circ}$ e $38^{\prime} \mathrm{W}$. O clima da região é o tipo Cwa, segundo a classificação de Koeppen, isto é, trata-se de clima mesotérmico, úmido, subtropical com inverno seco. De acordo com o Departamento de Ciências Exatas da USP/ESALQ, a temperatura média do mês mais quente está acima de $24^{\circ} \mathrm{C}$ e a do mês 
mais frio abaixo de $17^{\circ} \mathrm{C}$, apresentando uma precipitação pluvial média anual de $1200 \mathrm{~mm}$.

O experimento foi instalado na primeira semana de dezembro de 1999. O método escolhido, para determinar o número de sementes não dormentes, foi pela germinação em bandejas, o mesmo procedimento usado por Caetano (2000). O solo foi amostrado no campo com um trado de $4,3 \mathrm{~cm}$ de diâmetro, foram coletadas seis subamostras de cada subparcela do experimento descrito no Capítulo 3, na profundidade de $10 \mathrm{~cm}$, as quais foram colocadas em um balde de plástico, onde foi realizada a homogeneização destas amostras, que foram colocadas em sacos plásticos, devidamente identificados e levados ao laboratório para serem processados. Para determinação do número de sementes viáveis nāo dormentes, retirou-se de cada amostra composta, quatro subamostras, que foram passadas (1 Kg/amostra) em peneira grossa (malha de $0,280 \mathrm{~mm}$ ). Foram então colocadas em bandejas de alumínio com dimensões de $30 \mathrm{~cm} \times 20 \mathrm{~cm} \times 5 \mathrm{~cm}$, formando uma camada de solo de aproximadamente $2 \mathrm{~cm}$ de profundidade nas bandejas, que foram devidamente identificadas $\mathrm{e}$ levadas para a casa-de-vegetação, onde foram irrigadas de quatro a cinco vezes por dia, até o final das avaliações. O sistema de irrigação era composto por microaspersores que eram controlados por um "timer", irrigando aproximadamente $5 \mathrm{~mm}$ cada vez que era acionado. A casa de vegetação possui um sistema automático de controle de temperatura $\mathrm{e}$ umidade relativa, através de ventiladores, e a luminosidade era controlada por uma cobertura de sombrite que era, automaticamente, distendida de acordo com a luminosidade incidente.

As avaliações foram realizadas aos 30 e 60 dias após a instalação do experimento em casa-de-vegetação, onde as plântulas que emergiram foram identificadas por espécie, contadas e retiradas da bandeja. 
O delineamento experimental utilizado foi o de blocos casualizados com quatro repetições e no esquema fatorial, utilizando dois fatores de estudo, ou seja, adubos verdes e plantas daninhas, da seguinte forma: três adubos verdes (Arachis pintoi, Crotalaria juncea e Cajanus cajan), quatro plantas daninhas (Brachiaria decumbens, Panicum maximum, Bidens pilosa e infestação natural do solo), num total de 48 subparcelas.

Os resultados obtidos foram analisados através da Análise de Variância, com o auxilio do Sistema de Análise Estatística - SANEST, sendo que as interaçōes significativas tiveram suas médias comparadas entre si através do teste Tukey, ao nível de 5\% de probabilidade. Para a análise estatística os dados foram transformados segundo $\sqrt{x+0,5}$ para satisfazer a necessidade de distribuição normal dos resultados.

\subsection{Resultados e Discussão}

Nas Tabelas 4.1 e 4.2 estão apresentadas as médias de densidade de plantas daninhas em plantas/vaso da primeira e da segunda avaliação.

Analisando-se, em colunas, na Tabela 4.1, a primeira avaliação das médias de densidade de plantas daninhas/vaso, verificase que, para a planta daninha capim braquiária, o pior resultado de controle foi encontrado no tratamento com Arachis pintoi, sendo que, as médias dos tratamentos com Crotalaria juncea, Cajanus cajan e testemunha não diferiram, entre si, significativamente. No capim colonião, o melhor resultado de controle foi obtido com Crotalaria juncea, cujas médias dos tratamentos não diferiram de forma significativa das médias dos tratamentos onde foram utilizados Cajanus cajan e Arachis pintoi, as quais mostraram diferenças significativas 
quando comparadas com a média da testemunha. Em relação ao picão preto, o melhor controle foi obtido com a Crotalaria juncea, seguida por Cajanus cajan e Arachis pintoi, sendo que a média dos tratamentos com Crotalaria juncea não diferiu, estatisticamente, da média dos tratamentos com Arachis pintoi e esta não diferiu do controle proporcionado pelo Cajanus cajan. No entanto, todas as médias diferiram significativamente da média da testemunha. $\mathrm{E}$, na infestação natural, a Crotalaria juncea foi mais eficiente, seguida por Cajanus cajan e Arachis pintoi. Nesse caso, as médias de todos os tratamentos apresentaram diferenças significativas quando comparadas com a média da testemunha.

Tabela 4.1. Número de plantas daninhas por vaso que germinaram em solo provenientes de áreas com os adubos verdes, aos 30 dias após instalação do experimento. Experimento de casade-vegetação - Piracicaba, 2000 - USP/ESALQ.

\begin{tabular}{|c|c|c|c|c|}
\hline \multirow[b]{2}{*}{ Adubos verdes 1} & \multicolumn{4}{|c|}{ Plantas daninhas (plantas/vaso) } \\
\hline & $\begin{array}{l}\text { Brachiaria } \\
\text { decumbens }\end{array}$ & $\begin{array}{l}\text { Panicum } \\
\text { maximum }\end{array}$ & $\begin{array}{l}\text { Bidens } \\
\text { pilosa }\end{array}$ & $\begin{array}{c}\text { Infestação } \\
\text { natural }\end{array}$ \\
\hline Arachis pintoi & $26,1 \mathrm{a}^{2} \mathrm{~B}$ & $8,0 \mathrm{abC}$ & $2,6 \mathrm{bcC}$ & $76,6 \mathrm{bA}$ \\
\hline Crotalaria juncea & $1,4 \mathrm{bB}$ & $1,2 \mathrm{bB}$ & $1,00 \mathrm{cB}$ & $39,0 \mathrm{cA}$ \\
\hline Cajanus cajan & $4,5 \mathrm{bB}$ & $7,1 \mathrm{abB}$ & $9,4 \mathrm{bB}$ & $66,8 \mathrm{bA}$ \\
\hline Testemunha (s/capina) & $7,3 \mathrm{bC}$ & $13,6 \mathrm{aBC}$ & $29,3 \mathrm{aB}$ & $153,8 \mathrm{aA}$ \\
\hline Cv parcela $=17,87 \%$ & & \multicolumn{3}{|c|}{ Cv subparcela $=13,89$} \\
\hline $\operatorname{DMS}(1)=1,85$ & & \multicolumn{3}{|c|}{$\operatorname{DMS}(2)=1,98$} \\
\hline
\end{tabular}

1Dados foram transformados segundo $\sqrt{\mathrm{x}+0,5}$;

${ }^{2}$ Médias seguidas por letras distintas maiúsculas na linha e minúsculas na coluna diferem entre si a 5\% de significância pelo teste de Tukey. 
Tabela 4.2. Número de plantas daninhas por vaso que germinaram em solo provenientes de áreas com os adubos verdes, aos 60 dias após instalação do experimento. Experimento de casade-vegetação - Piracicaba, 2000 - USP/ESALQ.

\begin{tabular}{|c|c|c|c|c|}
\hline \multirow[b]{2}{*}{ Adubos verdes 1} & \multicolumn{4}{|c|}{ Plantas daninhas (plantas/vaso) } \\
\hline & $\begin{array}{l}\text { Brachiaria } \\
\text { decumbens }\end{array}$ & $\begin{array}{l}\text { Panicum } \\
\text { maximum }\end{array}$ & $\begin{array}{l}\text { Bidens } \\
\text { pilosa }\end{array}$ & $\begin{array}{c}\text { Infestação } \\
\text { natural }\end{array}$ \\
\hline Arachis pintoi & $2,0 \mathrm{a}^{2} \mathrm{~B}$ & $5,0 \mathrm{aB}$ & $1,0 \mathrm{aB}$ & $37,4 \mathrm{bA}$ \\
\hline Crotalaria juncea & $1,0 \mathrm{aB}$ & $1,2 \mathrm{aB}$ & $1,0 \mathrm{aB}$ & $22,2 \mathrm{bA}$ \\
\hline Cajanus cajan & $1,0 \mathrm{aB}$ & $3,5 \mathrm{aB}$ & $1,0 \mathrm{aB}$ & $35,2 \mathrm{bA}$ \\
\hline Testemunha (s/capina) & $1,0 \mathrm{aB}$ & $3,6 \mathrm{aB}$ & $1,8 \mathrm{aB}$ & 107,6 aA \\
\hline $\mathrm{Cv}$ parcela $=27,50 \%$ & & \multicolumn{3}{|c|}{ Cv subparcela $=18,16 \%$} \\
\hline $\operatorname{DMS}(1)=1,51$ & & \multicolumn{3}{|c|}{$\operatorname{DMS}(2)=1,53$} \\
\hline
\end{tabular}

1Dados foram transformados segundo $\sqrt{\mathrm{x}+0,5}$;

2Médias seguidas por letras distintas maiúsculas na linha e minúsculas na coluna diferem entre si a 5\% de significância pelo teste de Tukey.

Analisando a Tabela 4.2, em linhas, pode-se verificar que o Arachis pintoi foi mais eficiente no controle da emergência de sementes de picão preto, seguido pelo capim colonião, capim braquiária e infestação natural. A Crotalaria juncea foi mais efetiva no controle da emergência de sementes de picão preto, capim colonião, capim braquiária e infestação natural. E o Cajanus cajan controlou com mais eficiência a emergência de sementes de capim braquiária, capim colonião, picão preto e infestação natural.

Na Tabela 4.2, a segunda avaliação das médias de densidade de plantas daninhas/vaso, nota-se que, em relação ao capim braquiária, capim colonião e picão preto, não houve diferenças significativas entre as médias dos tratamentos, inclusive quando 
comparadas com as médias da testemunha. Apenas na infestação natural houve diferenças significativas entre as médias dos tratamentos e da testemunha, sendo que as médias dos tratamentos não diferiram de forma significativa quando comparadas entre si.

Analisando-se a Tabela 4.2, em linhas, verifica-se que, excetuando-se a infestação natural, as médias dos tratamentos não apresentaram diferenças significativas quando comparadas entre si e com as médias das testemunhas. Já, em relação à infestação natural, as médias dos tratamentos não diferiram significativamente quando comparadas entre si, mas todas apresentaram diferenças significativas quando comparadas com a média da testemunha. Ainda, nesta segunda avaliação, pode-se observar que o efeito das leguminosas testadas foi menos pronunciado sobre a emergência das sementes das espécies de plantas daninhas estudadas, quando comparado com a primeira avaliação, apresentando, desta forma, uma redução nos fluxos de emergência posterior de sementes destas plantas daninhas.

\subsection{Conclusões}

a) A Crotalaria juncea é mais eficiente na redução da emergência de sementes de todas as plantas daninhas em estudo.

b) O Cajanus cajan é mais efetivo na redução da emergência de sementes de Brachiaria decumbens, Panicum maximum, Bidens pilosa e infestação natural.

c) O Arachis pintoi reduz a emergência de sementes de picão preto, de maneira significativa, seguido por capim colonião, capim braquiária e infestação natural. 
d) Todas as leguminosas em estudo reduzem a emergência de sementes das plantas daninhas analisadas, significando que a utilização da prática de adubação verde afeta o recrutamento do banco de sementes e conseqüentemente a dinâmica de populações de plantas daninhas, contribuindo, de forma significativa, na redução da infestação destas nos agroecossistemas e pode, assim, fazer parte do manejo integrado de plantas daninhas. 
ANEXO 
Tabela 4.3. Resumo do Quadro da Análise de Variância do Experimento.

\begin{tabular}{lcll}
\hline & & \multicolumn{2}{c}{ Quadrados médios (Prob $>$ F) } \\
\cline { 3 - 4 } CV & GL & Densidade I & Densidade II \\
\hline Adubo verde & 3 & $34,5994(0,0000)$ & $7,8507(0,0017)$ \\
Blocos & 3 & $2,0167(0,0696)$ & $0,9751(0,2579)$ \\
Resíduo (A) & 3 & 0,6047 & 0,6122 \\
P.D & 9 & $148,8310(0,0000)$ & $114,2120(0,0000)$ \\
Ad. * P.D & 3 & $6,8396(0,0000)$ & $5,7903(0,0000)$ \\
Resíduo (B) & 9 & 1,0822 & 0,6423 \\
\hline
\end{tabular}




\section{SELETIVIDADE DE HERBICIDAS EM PRÉ E PÓS-EMERGÊNCIA DO ADUBO VERDE PERENE Arachis pintoi}

\section{Resumo}

Com o objetivo de avaliar a produção de biomassa seca e fitotoxicidade de herbicidas ao adubo verde perene amendoim forrageiro (Arachis pintoi), quando submetido a pulverizações de herbicidas aplicados em condições de pré e pós-emergência, foram instalados dois experimentos, em casa de vegetação, na Escola Superior de Agricultura "Luiz de Queiroz", Universidade de São Paulo, Departamento de Produção Vegetal, Piracicaba-SP. Os experimentos foram conduzidos em blocos casualizados, quatro repetições e seis tratamentos. Os herbicidas aplicados em pré-emergência foram: trifluralin (1,35 $\mathrm{Kg}$ i.a./ha), diuron $(1,5 \mathrm{Kg}$ i.a./ha), oxifluorfen $(0,6 \mathrm{Kg}$ i.a./ha), atrazine $(2,0 \mathrm{Kg}$ i.a./ha) e metolachlor $(2,88 \mathrm{Kg}$ i.a./ha) e, os pós-emergentes foram: fluazifop-pbutil $(0,25 \mathrm{Kg}$ i.a./ha), MSMA $(1,92 \mathrm{~kg}$ i.a./ha), glyphosate $(0,72 \mathrm{Kg}$ i.a./ha), glufosinato de amônio $(0,4 \mathrm{Kg}$ i.a./ha) e sulfosate $(0,96 \mathrm{Kg}$ i.a./ha). As avaliações foram realizadas aos 30, 45, 60 e 75 dias após a aplicação, para os herbicidas pré-emergentes e aos 7, 14, 21 e 28 dias após a aplicação para os pós-emergentes. Os resultados permitiram concluir que os herbicidas atrazine, glyphosate, glufosinato de amônio e sulfosate, nas doses aplicadas, não devem ser indicados para esta 
situação, enquanto que os herbicidas trifluralin, oxiflurfen e metolachlor devem ser recomendados com restrições $\mathrm{e}$ os herbicidas diuron, fluazifop-p-butil e. MSMA podem ser indicados para a situação apresentada. Ainda, conclui-se que, as aplicações de herbicidas préemergentes, de forma geral, causaram menor fitotoxicidade e, conseqüentemente, propiciaram menor redução na produção de biomassa seca do Arachis pintoi, do que os herbicidas aplicados em pósemergência.

SELECTIVITY OF HERBICIDES APPLIED IN PRE AND POSTEMERGENCE OF THE PERENNIAL COVER CROP Arachis pintoi

\section{Summary}

Two experiments were installed under greenhouse conditions at Escola Superior de Agricultura "Luiz de Queiroz", Piracicaba - SP, Brazil, in order to evaluate the dry biomass production and fitotoxicity of pre and post-emergence herbicides in the perennial cover crop Arachis pintoi. The experiment were conducted in randomized complete blocks, four replications, six treatments. The herbicides sprayed in pre-emergence conditions (one experiment) were trifluralin at $0.25 \mathrm{~kg}$ a.i./ha, diuron at $1.5 \mathrm{~kg}$ a.i./ha, oxyfluorfen at $0.60 \mathrm{~kg}$ a.i./ha, atrazine at $2.0 \mathrm{~kg}$ a.i./ha, metolachlor at $2.88 \mathrm{~kg}$ a.i./ha, and check plot without herbicide application. In the experiment of post-emergence herbicides the treatments were fluazifop-p-butyl at $0.25 \mathrm{~kg}$ a.i./ha, MSMA at $1.92 \mathrm{~kg}$ a.i./ha, glyphosate at $0.72 \mathrm{~kg}$ a.i./ha, ammoniumglufosinate at $0.40 \mathrm{~kg}$ a.i./ha, sulfosate at $0.96 \mathrm{~kg}$ a.i./ha and check plot without herbicide application. The evaluations were made at 30,45 , 60 and 75 days after pre-emergence herbicide treatments, and 7, 14, 21 
and 28 days after post-emergence herbicide treatments. The results allowed the conclusion that atrazine, glyphosate, ammonium-glufosinate and sulfosate, at the sprayed rates in the experiments, should not be applied on the cover crop; however, the herbicides trifluralin, oxyfluorfen and metolachlor can be sprayed at recommended crop rates, with some effects on the development of $A$. pintoi. Diuron, fluazifop-p-butyl and MSMA are completely selective to the green manure. It can also be concluded, from the experiment that, in general, pre-emergence treatments are more selective to $A$. pintoi than post-emergence herbicides, causing lower fitotoxicity and dry biomass reduction, when compared to post-emergence herbicides.

\subsection{Introdução}

$\mathrm{O}$ amendoim forrageiro (Arachis pintoi), planta nativa do Brasil Central, cuja propagação ocorre através de sementes e estolhos, vem apresentando bons resultados como cobertura e adubação verde do solo, em pomares de cítricos do estado da Flórida (Estados Unidos da América do Norte) e da Costa Rica. Dentre as características vantajosas de sua utilização destaca-se a capacidade de fixar nitrogênio no solo, controle de erosão, redução de infestação de plantas daninhas, patógenos, insetos, nematóides, não interferindo nas práticas culturais adotadas por estes citricultores (Coleman, 1995).

Numerosos trabalhos de pesquisa relatam a supressão de plantas daninhas causada pelas coberturas verdes, demonstrando o efeito destas no controle de plantas daninhas em condições de campo, sem o uso de herbicidas ou outras formas de manejo (Facelli and Pickett, 1991; Hartwig, 1989; Enache e Ilniki, 1990; White e Scott, 1991; DeHaan et al., 1994). 
Estudos da supressão de plantas daninhas pelas coberturas verdes, na cultura da ervilha, demonstraram bons resultados, variando entre os diferentes tipos de materiais utilizados (Al-Khatib et al., 1997). Pizarro et al. (1997), estudaram a produção e persistência de Arachis pintoi associada com Paspalum maritimum, em pastagens do cerrado brasileiro, sem o uso de herbicidas para o controle de plantas infestantes e verificaram que, ao final de dois anos, Arachis pintoi representava $60 \%$ da cobertura vegetal do solo, apresentando boas condições sanitárias e de vigor. Os autores também notaram resultados positivos no controle de erosão e plantas daninhas. Por outro lado, outros autores mencionam que a infestação de plantas daninhas constituiu na principal limitação no estabelecimento de algumas espécies de adubos verdes em culturas anuais, reduzindo, em alguns casos, a produtividade econômica destas (Wilkinson et al., 1987; Mohler, 1991).

Desta maneira, não obstante os adubos verdes, utilizados como coberturas vivas, possam fazer parte de um conjunto de medidas efetivas para a redução da infestação de populações de plantas daninhas, existe a necessidade de se realizar um manejo de plantas daninhas nestes adubos verdes, até que estejam estabelecidos, com o objetivo de prevenir a invasão e o estabelecimento de espécies de plantas infestantes com o tempo (Teasdale, 1998).

Entre as medidas utilizadas para o controle de plantas daninhas, bem como regular o crescimento de adubos verdes, utilizados como cobertura viva do solo, está o uso de herbicidas. O herbicida é então utilizado com dois objetivos, isto é, eliminar a competição da planta daninha durante o estabelecimento do adubo verde e reduzir o crescimento dos adubos verdes que eventualmente possam competir com a cultura em convivência. 
A alfafa (Medicago sativa L.) pode ter seu crescimento suprimido por doses subletais de atrazine, mas, no entanto, pode se regenerar a partir de brotações das gemas dos ramos inferiores, revertendo desta forma o efeito do herbicida (Eberlein et al., 1992). Outros autores, também, verificaram que subdoses de herbicidas podem ser empregadas para proporcionar o controle do crescimento de coberturas vivas (Elkins et al., 1983; Hartwig, 1987).

Desta forma, este experimento tem como objetivo estudar, o efeito da aplicação de herbicidas pré e pós-emergentes, através da avaliação de fitotoxicidade e de produção de biomassa seca do Arachis pintoi, visando obter informações técnicas que possam contribuir no controle do crescimento desse adubo verde e controle de plantas daninhas.

\subsection{Material e Métodos}

O experimento foi conduzido, em casa-de-vegetaçāo do Departamento de Produção Vegetal da Escola Superior de Agricultura "Luiz de Queiroz", campus da ESALQ/USP, em Piracicaba - SP, cujo municipio apresenta as seguintes coordenadas geográficas: altitude de $560 \mathrm{~m}$, latitude de $22^{\circ}$ e $45^{\prime}$. Sul e longitude de $47^{\circ}$ e $38^{\prime} \mathrm{W}$. O clima da região é o tipo Cwa, segundo a classificação de Koeppen, isto é, trata-se de clima mesotérmico, úmido, subtropical com inverno seco. De acordo com o Departamento de Ciências Exatas da USP/ESALQ, a temperatura média do mês mais quente está acima de $24^{\circ} \mathrm{C}$ e a do mês mais frio abaixo de $17^{\circ} \mathrm{C}$, apresentando uma precipitação média anual de 1200 $\mathrm{mm}$.

$\mathrm{O}$ ensaio constou de duas fases. Na primeira foi coletado solo (primeira semana de setembro de 1999) da área próxima ao local 
onde estava instalado o experimento de campo, descrito no Capitulo 3, a qual exibia alta infestação natural de plantas daninhas, composta por mono e dicotiledôneas. Esta coleta foi feita com trado de $4,3 \mathrm{~cm}$ de diâmetro, a $10 \mathrm{~cm}$ de profundidade e de maneira aleatória (o volume de solo coletado foi o necessário para encher os vasos). Após, este solo foi colocado em sacos plásticos, levado ao laboratório, peneirado (peneira com malha de $0,280 \mathrm{~mm}$ ) para desfazer possiveis agregados e colocado em vasos plásticos de $205 \mathrm{~cm}^{3}$ de capacidade. Em seguida, foram cuidadosamente semeadas 10 sementes de Arachis pintoi/vaso, inclusive nos vasos onde seriam, posteriormente, realizados os tratamentos em pós-emergência. Antes da aplicação em pré-emergência, os vasos foram irrigados, com o equivalente a uma chuva de $15 \mathrm{~mm}$, visando melhorar as condições de umidade. A seguir, foram submetidos à aplicação de herbicidas em pré-emergência, tanto do Arachis pintoi, como das plantas daninhas, que foi realizada em câmara de aplicação, com pressão de $40 \mathrm{Lbs} / \mathrm{pol}^{2}$, utilizando-se pontas $110.02 \mathrm{E}$, com volume de calda aplicado equivalente a $300 \mathrm{~L} / \mathrm{ha}$, sendo que os tratamentos encontram-se descritos na Tabela 5.1. Depois, todos os vasos foram levados para a casa de vegetação, onde foram submetidos a sistema de regas diárias, fazendo-se a utilização deste quantas vezes fossem necessárias. O sistema de irrigação era composto por microaspersores que eram controlados por um "timer", irrigando aproximadamente $5 \mathrm{~mm}$ cada vez que era acionado. A casa de vegetação possui um sistema automático de controle de temperatura e umidade relativa, através de ventiladores e a luminosidade era controlada por uma cobertura de sombrite que era, automaticamente, distendida de acordo com a luminosidade incidente.

Depois de 14 dias da instalação da primeira fase, foi montada a segunda, pois, somente após este periodo é que o Arachis pintoi apresentava boas condiçōes vegetativas para que as aplicações em 
pós-emergència pudessem ser realizadas. Assim, todos os vasos que seriam submetidos à aplicação em pós-emergência, foram retirados da casa-de-vegetação e levados para a câmara de aplicação, onde se utilizou novamente pressão de $40 \mathrm{Lbs} / \mathrm{pol}^{2}$, pontas $110.02 \mathrm{E}$ e volume de calda equivalente a $300 \mathrm{~L} / \mathrm{ha}$. Os tratamentos em pós-emergência estão representados na Tabela 5.2. Neste caso, os vasos só retornaram para a casa de vegetação depois de oito horas após a aplicação, onde foram novamente submetidos a regas freqüentes, de três a quatro vezes por dia, até o final das avaliações.

Tabela 5.1. Tratamentos utilizados no experimento instalado em condições de pré-emergência - Experimento de casa-devegetação. Piracicaba, 2000 - USP/ESALQ.

\begin{tabular}{|c|c|c|c|c|}
\hline \multirow[b]{2}{*}{ Tratamentos } & \multirow[b]{2}{*}{ Herbicidas } & \multirow[b]{2}{*}{ Formulação } & \multicolumn{2}{|c|}{ Doses } \\
\hline & & & $\begin{array}{c}\text { i.a. } \\
\text { (kg/ha) }\end{array}$ & $\begin{array}{c}\text { p.c } \\
\text { (L/ha) }\end{array}$ \\
\hline 1 & Trifluralin ${ }^{1}$ & $450 \mathrm{CE}$ & 1,35 & 3,0 \\
\hline 2 & Diuron $^{2}$ & $500 \mathrm{SC}$ & 1,50 & 3,0 \\
\hline 3 & Oxifluorfen $^{3}$ & $240 \mathrm{CE}$ & 0,60 & 2,5 \\
\hline 4 & Atrazine $^{4}$ & $500 \mathrm{SC}$ & $\cdot 2,0$ & 4,0 \\
\hline 5 & Metolachlor 5 & $960 \mathrm{CE}$ & 2,88 & 3,0 \\
\hline 6 & Testemunha sem herbicida & - & - & - \\
\hline
\end{tabular}

('Produto comercial utilizado Trifluralina Nortox, formulação concentrado emulsionável, contendo $450 \mathrm{~g} / 1$, produzido pela Nortox.

(2)Produto comercial utilizado Karmex, formulação suspensão concentrada, contendo $500 \mathrm{~g} / 1$, produzido pela DU PONT do Brasil.

(3)Produto comercial utilizado Goal BR, formulação concentrado emulsionável, contendo $240 \mathrm{~g} / 1$, produzido pela Rohm and Haas.

(4)Produto comercial utilizado Gesaprim, formulação suspensão concentrada, contendo $500 \mathrm{~g} / 1$, produzido pela Novartis Agribussiness.

(5)Produto comercial utilizado Dual, formulação concentrado emulsionável, contendo $960 \mathrm{~g} / 1$, produzido pela Novartis Agribussiness.

i.a. $=$ ingrediente ativo; p.c. $=$ produto comercial 
Tabela 5.2. Tratamentos utilizados no experimento instalado em condiçōes de pós-emergência. - Experimento de casa-devegetação. Piracicaba, 2000 - USP/ESALQ.

\begin{tabular}{clccc}
\hline & & & \multicolumn{2}{c}{ Doses } \\
\cline { 4 - 5 } Tratamentos & \multicolumn{1}{c}{ Herbicidas } & Formulação & $\begin{array}{c}\text { i.a. } \\
\text { (kg/ha) }\end{array}$ & $\begin{array}{c}\text { p.c. } \\
\text { (L/ha) }\end{array}$ \\
\hline 1 & Fluazifop-p-buti1 $^{1}$ & $125 \mathrm{CE}$ & 0,25 & 2,0 \\
2 & MSMA $^{2}$ & $480 \mathrm{SA}$ & 1,92 & 4,0 \\
3 & Glyphosate $^{3}$ & $360 \mathrm{SA}$ & 0,72 & 2,0 \\
4 & Glufosinato de amônio $^{4}$ & $200 \mathrm{CE}$ & 0,40 & 2,0 \\
5 & Sulfosate $^{5}$ & $480 \mathrm{SA}$ & 0,96 & 2,0 \\
6 & Testemunha sem herbicida $^{2}$ & - & - & - \\
\hline
\end{tabular}

(1Produto comercial utilizado Fusilade, formulação concentrado emulsionável, contendo $125 \mathrm{~g} / 1$, produzido pela Zeneca.

(2)Produto comercial utilizado Daconate, formulação suspensão concentrada, aquosa contendo $480 \mathrm{~g} / 1$, produzido pela Zeneca.

(3)Produto comercial utilizado Roundup, formulação suspensão aquosa, contendo 360 $\mathrm{g} / 1$, produzido pela Monsanto.

(4) Produto comercial utilizado Finale, formulação concentrado emulsionáve1, contendo $200 \mathrm{~g} / 1$, produzido pela Aventis.

(5)Produto utilizado Zapp, formulação suspensão aquosa, contendo $480 \mathrm{~g} / 1$, produzido pela Zeneca.

i.a. $=$ ingrediente ativo e p.c. $=$ produto comercial.

O delineamento experimental utilizado, de ambos os experimentos, foi o de blocos casualizados com quatro repetições, seis tratamentos.

Durante a condução do experimento, os parâmetros avaliados foram os seguintes: quatro avaliações de fitotoxicidade ao Arachis pintoi, causada pelos herbicidas, para o experimento em préemergência realizadas aos 30, 45, 60 e 75 dias após a aplicação; quatro avaliações de fitotoxicidade ao Arachis pintoi, causada pelos herbicidas 
pós-emergentes, efetuadas aos 7, 14, 21 e 28 dias após a aplicação. Estas avaliações de fitotoxicidade foram realizadas através da Escala EWRC, onde 1 significa ausência total de injúria e 9, morte total da planta. No final, foi feita a avaliação de produção de biomassa seca do Arachis pintoi em todos os tratamentos (g/vaso). Na casa de vegetação foi realizado, cuidadosamente, o corte da parte aérea das plantas de Arachis pintoi, e essas amostras foram colocadas em pequenos sacos de papel, devidamente identificadas e levadas ao laboratório para secagem em estufa a $50^{\circ} \mathrm{C}$ durante 48 horas e pesagem em balança de precisão.

Os dados de biomassa seca obtidos foram analisados através da Análise de Variância, com o auxílio do Sistema de Análise Estatistica - SANEST, sendo as médias comparadas entre si através do teste Tukey, ao nível de $5 \%$ de probabilidade. Os resultados de fototoxicidade não foram avaliados estatisticamente.

\subsection{Resultados e Discussão}

Nas Tabelas 5.3 e 5.4 estão apresentadas as médias de produção de biomassa seca (em g/vaso) e de fitotoxicidade do Arachis pintoi (Escala EWRC), quando submetido a aplicação de herbicidas pré e pós-emergentes.

Analisando-se a produção de biomassa seca do Arachis pintoi, Tabela 5.3, no tocante a produção de biomassa seca do Arachis pintoi, quando submetido a aplicaçōes em pré-emergência, verifica-se que, a média dos tratamentos com o herbicida diuron foi a única que não diferiu significativamente da média da testemunha, enquanto que as médias dos tratamentos com os herbicidas trifluralin, oxifluorfen e metolachlor nāo apresentaram diferenças significativas entre si. No entanto, a média do tratamento com o herbicida atrazine apresentou diferenças significativas quando comparada com as demais médias. 
Tabela 5.3. Médias de produção de biomassa seca (g/vaso) e de fitotoxicidade do Arachis pintoi submetido a aplicações de herbicidas em pré-emergência. Experimento de casa-devegetação. Piracicaba, 2000 - USP/ESALQ.

\begin{tabular}{lcccccc}
\hline & Dose & MS & \multicolumn{4}{c}{ FITOTOXICIDADE } \\
\cline { 5 - 7 } Tratamentos $^{1}$ & (kg i.a./ha) & (g/vaso) & 30 DAA & 45 DAA & 60 DAA & 75 DAA \\
\hline Trifluralin & 1,35 & $5,1 \mathbf{b}^{2}$ & 1,0 & 1,2 & 1,2 & 1,0 \\
Diuron & 1,5 & $6,0 \mathrm{a}$ & 1,2 & 1,0 & 1,0 & 1,0 \\
Oxifluorfen & 0,6 & $5,1 \mathrm{~b}$ & 2,8 & 2,0 & 1,0 & 1,0 \\
Atrazine & 2,0 & $0,0 \mathrm{c}$ & 7,8 & 9,0 & 9,0 & 9,0 \\
Metolachlor & 2,88 & $4,8 \mathrm{~b}$ & 1,2 & 1,2 & 1,0 & 1,0 \\
Testemunha & - & $6,2 \mathrm{a}$ & 1,0 & 1,0 & 1,0 & 1,0 \\
\hline CV $=8,86 \%$ & DMS $=0,8$ & & & & & \\
\hline
\end{tabular}

1Para a análise estatística os dados foram transformados segundo $\sqrt{x+0,5}$

2 Médias seguidas por letras distintas minúsculas na coluna diferem entre si a $5 \%$ de significância pelo teste de Tukey

DAA: dias após a aplicação

ESCALA EWRC: $\quad 1$ = Ausência total de injúria $\quad 9$ = morte total

Tabela 5.4. Médias de produção de biomassa seca (g/vaso) e de fitotoxicidade do Arachis pintoi submetido a aplicações de herbicidas em pós-emergentes. Experimento de casa-devegetação. Piracicaba, 2000 - USP/ESALQ.

\begin{tabular}{lcccccc}
\hline & Dose & MS & \multicolumn{5}{c}{ FITOTOXICIDADE } \\
\cline { 5 - 7 } Tratamentos $^{1}$ & (kg i.a./ha) & (g/vaso) & 30 DAA & 45 DAA & 60 DAA & 75 DAA \\
\hline Fluazifop-p-butil & 0,25 & $5,3 \mathbf{a}^{2}$ & 1,2 & 1,2 & 1,0 & 1,0 \\
MSMA & 1,92 & $5,8 \mathbf{a}$ & 3,8 & 3,8 & 2,0 & 1,2 \\
Glyphosate & 0,72 & $0,0 \mathrm{~b}$ & 7,2 & 8,8 & 9,0 & 9,0 \\
Glufosinato de amônio & 0,4 & $0,0 \mathrm{~b}$ & 8,0 & 8,2 & 9,0 & 9,0 \\
Sulfosate & 0,96 & $0,0 \mathrm{~b}$ & 7,2 & 8,8 & 9,0 & 9,0 \\
Testemunha & & $6,5 \mathbf{a}$ & 1,0 & 1,0 & 1,0 & 1,0 \\
\hline CV $=22,9 \%$ & & & & & &
\end{tabular}

1Para a análise estatistica os dados foram transformados segundo $\sqrt{\mathrm{x}+0,5}$;

2 Médias seguidas por letras distintas minúsculas na coluna diferem entre si a $5 \%$ de significância pelo teste de Tukey

DAA: dias após a aplicação

ESCALA EWRC: $\quad 1$ = Ausência total de injúria $\quad 9$ = morte total 
Observando-se a Tabela 5.3, em relação à avaliação de fitotoxicidade do Arachis pintoi, pela Escala EWRC, quando submetido a aplicaçōes de herbicidas pré-emergentes, nota-se que, na primeira avaliação, aos 30 dias após a aplicação, os tratamentos com os herbicidas trifluralin, diuron e metolachlor, obtiveram resultados próximos do resultado da testemunha. Os tratamentos com oxifluorfen apresentaram injúria leve, enquanto que os tratamentos com atrazine já apresentavam grande diferença dos demais tratamentos, causando injúrias moderadas. Nas avaliações seguintes, aos 45 e 60 dias após a aplicação, os resultados se mantiveram quase inalterados, sendo que os tratamentos com o herbicida atrazine já apresentavam injúria total da planta. E, na última avaliação, realizada aos 75 dias após a aplicação, os tratamentos com os herbicidas trifluralin, diuron, oxifluorfen e metolachlor não apresentaram nenhum tipo de fitotoxicidade no Arachis pintoi, quando comparados com a testemunha, enquanto que os tratamentos com atrazine levaram a planta à morte.

Observando-se, a Tabela 5.4, no que diz respeito à produção de biomassa seca do Arachis pintoi, quando submetido a aplicações em pós-emergência, nota-se que, as médias dos tratamentos com os herbicidas fluazifop-p-butil e MSMA não apresentaram diferenças significativas em comparação com a média da testemunha, enquanto que as médias dos tratamentos com os herbicidas glyphosate, glufosinato de amônio e sulfosate, não diferiram signicativamente quando comparadas entre si, mas mostraram diferenças significativas em comparação com a média dos tratamentos com fluazifop-p-butil, MSMA e testemunhạ.

Verificando-se a Tabela 5.4 , em relação à avaliação de fitotoxicidade do Arachis pintoi, pela Escala EWRC, quando submetido a aplicações de herbicidas pós-emergentes, nota-se que, na primeira avaliação, aos sete dias após a aplicação, os tratamentos com os 
herbicidas glyphosate, glufosinato de amônio e sulfosate causaram injúrias severas no Arachis pintoi, enquanto que o tratamento com MSMA apresentou injúria leve e o tratamento com fluazifop-p-butil demonstrou ausência de injúria. Nas avaliaçōes subseqüentes, aos $14 \mathrm{e}$ 21 dias após a aplicação, os tratamentos com os herbicidas glyphosate, glufosinato de amônio e sulfosate causaram a morte da planta, enquanto que os resultados dos outros dois tratamentos mantiveram-se praticamente constantes. No final da última avaliação, aos 28 dias, os tratamentos fluazifop-p-butil e MSMA demonstravam ausência total de injúria, enquanto que os outros três tratamentos causaram a morte da planta.

\subsection{Conclusōes}

a) Dentre os herbicidas testados, o herbicida diuron é o que apresenta maior seletividade para o Arachis pintoi.

b) Os herbicidas, trifluralin, oxifluorfen e metolachlor apresentam boa seletividade, no entanto reduziram a produção de biomassa seca do Arachis pintoi e devem ser recomendados com restriçōes.

c) Os herbicidas fluazifop-p-butil e MSMA são seletivos ao Arachis pintoi, nas doses testadas neste experimento.

d) Os herbicidas atrazine, glyphosate, glufosinato de amônio e sulfosate não devem, nestas dosagens, serem indicados para o controle de plantas daninhas no Arachis pintoi. 
e) Maior número de pesquisas com outros herbicidas e dosagens devem ser desenvolvidas para que se possa ter, à disposiçāo, outras possibilidades de controle de plantas daninhas no Arachis pintoi, para fins de seu crescimento e estabelecimento, bem como para limitação de seu crescimento quando compete com a cultura principal. 
ANEXO 
Tabela 5.5. Resumo do Quadro de Análise de Variância da produção de biomassa seca do Arachis pintoi submetido a aplicaçōes de herbicidas pré e pós-emergentes. Experimento de casa-devegetação. Piracicaba, 2000 - USP/ESALQ.

\begin{tabular}{lccc}
\hline & \multicolumn{3}{c}{ Quadrados médios (Prob. > F) } \\
\cline { 2 - 4 } & GL & PRÉ & Pós \\
\hline Herbicidas & 5 & $26,3887(0,0000)$ & $53,1381(0,0001)$ \\
Blocos & 4 & $0,1304(0,5415)$ & $0,7986(0,1797)$ \\
Residuo & 20 & 0,1633 & 0,4584 \\
\hline Total & 29 & & \\
\hline
\end{tabular}




\section{CORRELAÇÕES ENTRE A PROFUNDIDADE DE INCORPORAÇÃO DA FITOMASSA DE ADUBOS VERdES E A SUPRESSÃo DE PLANTAS DANINHAS}

\section{Resumo}

Com o objetivo de avaliar as correlações existentes entre a utilização de diferentes quantidades de fitomassa, incorporada ou na superficie do solo, dos adubos verdes amendoim forrageiro (Arachis pintoi), crotalária (Crotalaria juncea L.) e feijāo guandu anão (Cajanus cajan L. Millsp.) sobre a redução da emergência e produção de biomassa seca das plantas daninhas capim braquiária (Brachiaria decumbens Stapf.), capim colonião (Panicum maximum Jacq.) e picão preto (Bidens pilosa L.), foi instalado um experimento, em casa-de-vegetação, na Escola Superior de Agricultura "Luiz de Queiroz", Universidade de São Paulo, Departamento de Produção Vegetal, Piracicaba-SP. O Delineamento Experimental utilizado foi o de blocos casualisados, com quatro repetições, em esquema fatorial $3 \times 6 \times 3 \times 2$, sendo três adubos verdes (Arachis pintoi, Crotalaria juncea e Cajanus cajan), seis tratamentos (quantidades de fitomassa: $0 ; 0,5 ; 1 ; 2 ; 4$ e 8 vezes a quantidade de adubo verde produzido - média de campo), três plantas daninhas (Brachiaria decumbens, Panicum maximum e Bidens pilosa) e 
duas profundidades (na superficie do solo e de 0 a $5 \mathrm{~cm}$ de profundidade). Os parâmetros avaliados durante a condução do experimento, foram os seguintes: duas avaliaçōes de contagem da infestação de plantas daninhas/vaso e duas avaliações de produção de biomassa seca das plantas daninhas (g/vaso), realizadas aos 15 e aos 30 dias após a instalação do experimento. Os resultados permitiram concluir que a fitomassa dos adubos verdes, nas duas formas utilizadas, reduz significativamente as populações das plantas daninhas testadas. As correlações ocorrem de maneira distinta pelos diferentes adubos verdes, sendo o Cajanus cajan, de forma geral, o mais efetivo na supressão das plantas daninhas.

\section{CORRELATION BETWEEN WEED SUPRESSION AND DEPTH OF COVER CROPS BIOMASS INCORPORATION}

\section{Summary}

Different biomass of the cover crops Arachis pintoi, Crotalaria juncea L. and Cajanus cajan L. Millsp. were either incorporated or spread on the surface of the soil, in order to study the effect on the emergence and dry biomass production of the weeds Brachiaria decumbens Stapf., Panicum maximum Jacq. and Bidens pilosa L. The experiment was installed in pots and conducted in the greenhouse conditions of the Department of Plant Production of ESALQ - University of São Paulo, Piracicaba - SP, Brazil. The experimental design used in the conduction of the experiment was factorial $3 \times 6 \times 3$ $\mathrm{x} 2$, being three cover crops (Arachis pintoi, Crotalaria juncea and Cajanus cajan), six treatments (amount of cover crop biomass, 0, 0.5, 1, 2,4 , and 8 times the average biomass produced in the field conditions), three weeds (Brachiaria decumbens, Panicum maximum, Bidens pilosa) 
and two depth of cover crop residue incorporation $(0$ and $5 \mathrm{~cm})$. The parameters evaluated were: two weed counting/pot, and weed dry biomass yield (g/pot), at 15 and 30 days after experiment setting. The results allowed the conclusion that the cover crop biomass, in the two depth of incorporation, reduce significantly the weed populations tested, however in different degrees of interference, being Cajanus cajan, in general, the most effective in the weed suppression.

\subsection{Introdução}

Há 2000 anos atrás, durante o reinado do imperador romano Augusto, encontrava-se, nos versos das Georgicas de Virgílio (Publius Vergilius Maro), citações da utilização da rotação de culturas e adubação orgânica, práticas agrícolas que, já segundo os antigos, melhoram as propriedades físicas, químicas e biológicas do solo (Primavesi,1986). Esquecidas por alguns sistemas de produção agrícola, estas práticas apresentam capacidade inquestionável de assegurar a vida e a fertilidade do solo, tornando a atividade agrícola menos dependente de insumos externos e mais sustentada nos próprios recursos da unidade produtora (Igue, 1984; Primavesi, 1986; Vogtmann \& Wagner, 1987; Bulisani et al., 1987; Piamonte, 1996; Coleman, 1995; Teasdale, 1998).

Rotacionar culturas significa alternar, regular e ordenar, cultivos de diferentes espécies vegetais, temporalmente, numa determinada área (Curl, 1963; Derpsch e Calegari, 1993).

Dentre as práticas de rotação de culturas destaca-se a utilização da adubação verde, especialmente com as leguminosas, cuja fitomassa é incorporada ao solo ou, em algumas situaçōes, deixada sobre a superficie deste. Geralmente, estas plantas são rústicas, com sistema radicular profundo e bem desenvolvido, que atinge as camadas 
mais profundas do solo absorvendo umidade e nutrientes necessários, que são armazenados nos caules e folhas. Após o corte, a fitomassa se decompõe e estes nutrientes são "devolvidos" ao solo, através do processo de decomposição desta massa vegetal e, em seguida, são absorvidos pelas culturas que exploram as camadas superficiais do terreno (Primavesi, 1986).

Além de fornecer nutrientes às plantas, esse rico farnel de matéria orgânica alimenta os bilhões de microorganismos que vivem sobre e sob a terra, e de cuja atividade dependem não apenas a manutenção da fertilidade do solo, mas também o aumento da resistência dos vegetais aos insetos e patógenos (Miyasaka, 1984; Primavesi, 1986). Possuem, também, a propriedade de fixar o nitrogênio do ar pela associação com certas bactérias do gênero Rhizobium, que vivem em suas raizes, o que pode representar para o agricultor uma substancial economia de nitrogênio, extraído do petróleo a elevados custos. Calcula-se que, se a prática da adubação verde fosse utilizada em quinze milhões de hectares, o Brasil estaria incorporando ao sistema solo-planta o equivalente a mais de um bilhão de dólares anuais em nitrogênio (Primavesi, 1986).

Não obstante, a rotação de culturas, incluindo a utilização de adubos verdes, tenha sido, bastante pesquisada anteriormente, grande parte destes trabalhos não estabelece relações com o controle de plantas infestantes (Christoffoleti, 1988). No entanto, as plantas daninhas nocivas têm grande dificuldade em manter uma população em uma determinada área, quando se emprega uma rotação sistemática de culturas de gramineas com outras plantas cultivadas (Walker \& Buchanan, 1982).

Assim, a fitomassa produzida pela adubação verde tem influência direta na supressão de plantas daninhas nos agroecossistemas, pois existe uma correlação linear entre a quantidade 
desta fitomassa e a efetiva redução da infestação por plantas daninhas, sendo que, diferentes espécies de adubos verdes modificam a composição da população das plantas daninhas infestantes na área (Almeida e Rodrigues 1985).

$\mathrm{Da}$ mesma forma, a cobertura morta altera as características físicas, químicas e biológicas do solo, modificando a constituição qualitativa e quantitativa do complexo florístico que se desenvolve nesse local, interferindo no processo de quebra de dormência das sementes e, pela sua ação alelopática, sobre a germinação e desenvolvimento das plântulas (Almeida, 1991). Comporta-se como uma camada isolante, interpondo-se entre o solo e a atmosfera, interceptando os raios solares, notadamente os vermelhos e infravermelhos, reduzindo a temperatura do terreno debaixo da cobertura morta, a amplitude térmica diurna e a evaporação de água, mantendo, assim, a umidade do solo (Vieira, 1981).

Em relação à luz, de acordo com Chancellor (1980 e 1982), sementes que possuem a proteina fitocromo $(\mathrm{P})$, a qual governa $o$ processo de dormência, na presença de raios vermelhos converte-se em formas que ativam a germinação e na sua ausência reverte-se à composição original, impedindo que germinem.

A água é essencial para o processo de germinação, que somente se inicia quando a semente fica embebida, o que depende da permeabilidade do tegumento. Segundo Popey (1976), há espécies em que a permeabilidade só se verifica após longo tempo de contato da semente com a água, outras exigem alternâncias de alto e baixo teor de água no solo.

A temperatura também tem grande influência na quebra da dormência das sementes. O requisito de temperatura para que a germinação se inicie varia de espécie para espécie, como por exemplo, espécies de verão e de inverno, enquanto que outras necessitam que a 
temperatura sofra alternações diuturnas para que a germinação se inicie (Chancellor, 1982).

Porém, estes fatores não atuam de forma independente. Notam-se fortes interaçōes entre eles, dificultando o entendimento do processo. Desta maneira, a quebra de dormência da semente de certas espécies, apenas se verifica em determinada combinação favorável de temperatura, umidade, luminosidade e de características intrinsecas da própria semente (Vincent \& Roberts, 1977).

Em relação a alelopatia, Molish (1937), a definiu como sendo a introdução, no ambiente comum, de substâncias químicas elaboradas por alguns elementos da comunidade e que afetam o comportamento de outros. Os compostos químicos responsáveis pela alelopatia são denominados aleloquímicos. Sua produção na célula obedece às leis da genética, sendo elaborados com finalidades específicas e, uma única planta, pode produzir centenas deles (Swain 1977). Cada espécie produz um conjunto diferente de aleloquímicos, com ação diferenciada sobre os componentes da comunidade onde está inserida (Putnam \& Duke, 1974).

A função essencial dos aleloquímicos é de proteger as plantas do ataque de patógenos, inibindo o desenvolvimento dos microorganismos, repelir ou atrair insetos, defendê-las de herbivoros pelo seu paladar desagradável e/ou por serem venenosos e reduzir a competição de outras plantas inibindo o seu desenvolvimento (Almeida, 1991). O mesmo autor cita a grande importância alelopática das palhadas em sistemas de plantio direto. Elaborados pelas plantas, os aleloquimicos mantêm-se nos tecidos mesmo depois da morte das mesmas e através da ação da chuva e do orvalho, vão sendo liberados para o solo, onde podem afetar a germinação de sementes, bem como o desenvolvimento de plântulas. Portanto, a quantidade de palha que forma a cobertura morta, influencia a intensidade do efeito alelopático, 
pois quanto maior, mais aleloquímicos contém e maior quantidade é liberada para o solo (Almeida, 1988).

Assim, o efeito das coberturas mortas depende do conjunto de suas caracteristicas, isto é, quantidade de palha que as forma, tipo de aleloquímicos que contém, a ação destes sobre as espécies que formam o complexo florístico da área e a taxa de decomposição do material vegetal (Almeida, 1991).

Desta maneira, um sistema de produção agrícola onde se utilize a prática da adubação verde traz, além dos beneficios normalmente citados, como incremento na produtividade, economia de adubo nitrogenado na cultura que a sucede no esquema de rotação ou de sucessão, a opção de ser uma valiosa ferramenta, para fazer parte de um sistema de manejo integrado de plantas daninhas.

Assim, no presente experimento, estudou-se a influência da quantidade de fitomassa de três espécies de leguminosas, aplicadas na superficie ou incorporada ao solo, sobre a redução da infestação de plantas daninhas. O ensaio visa obter dados, que analisados cientificamente, possam contribuir para explicação de como a supressão das plantas daninhas por adubos verdes pode contribuir positivamente para a produção agrícola.

\subsection{Material e Métodos}

A pesquisa foi conduzida, em casa-de-vegetação, na área experimental do Departamento de Produção Vegetal da Escola Superior de Agricultura "Luiz de Queiroz", campus da ESALQ/USP, em Piracicaba - SP, cujo municipio apresenta as seguintes coordenadas geográficas: altitude de $560 \mathrm{~m}$, latitude de $22^{\circ}$ e $45^{\prime}$ Sul e longitude de $47^{\circ}$ e $38^{\prime} \mathrm{W}$. O clima da região é o tipo Cwa, segundo a classificação de Koeppen, isto é, trata-se de clima mesotérmico, úmido, subtropical com inverno seco. De 
acordo com o Departamento de Ciências Exatas da ESALQ/USP, a temperatura média do mês mais quente está acima de $24^{\circ} \mathrm{C}$ e a do mês mais frio abaixo de $17^{\circ} \mathrm{C}$, apresentando uma precipitação média anual de $1200 \mathrm{~mm}$.

$O$ experimento foi instalado na segunda quinzena de dezembro de 1999. O solo foi coletado, do mesmo local onde estava sendo realizado o experimento de campo descrito no Capítulo 3 , com trado de $4,3 \mathrm{~cm}$ de diâmetro, na profundidade de $0-10 \mathrm{~cm}$, sendo essas amostras colocadas em sacos plásticos, levadas para o laboratório e peneiradas (peneira com malha de $0,280 \mathrm{~mm}$ ). Em seguida, foi realizado o enchimento dos vasos, com $200 \mathrm{~cm}^{3}$ de solo/vaso. Após, foram contadas 100 sementes de cada planta daninha, pesadas e devidamente identificadas, sendo que, as demais quantidades de plantas daninhas usadas foram, então, determinadas através do processo de pesagem. A seguir, foi realizada a coleta dos adubos verdes, que já estavam plantados, de acordo com o experimento de campo do Capitulo 3 (no momento da coleta, os adubos verdes estavam no estádio fenológico de início de florescimento). Esta coleta foi realizada medindo-se $3 \mathrm{~m}$ lineares de cada adubo verde que eram cuidadosamente cortados (apenas a parte aérea), colocados em sacos plásticos devidamente identificados e levados para o laboratório, onde eram picados, pesados e devidamente identificados. O cálculo da quantidade de adubo verde utilizada por vaso foi baseado na produção média da fitomassa em ton/ha, dos adubos verdes, do experimento de campo citado no Capitulo 3. Desta forma, correlacionou-se a área do vaso com a produção de adubo verde na mesma área no campo. As quantidades utilizadas dos adubos verdes, tanto na superficie dos vasos como de forma incorporada ao solo dos vasos, foram as seguintes: $0 \mathrm{x}, 0,5 \mathrm{x}, 1 \mathrm{x}, 2 \mathrm{x}, 4 \mathrm{x}$ e $8 \mathrm{x}$, sendo $0 \mathrm{x}$ a testemunha e $1 \mathrm{x}$ a quantidade calculada a partir do experimento de campo. 
No ensaio em que se utilizou os adubos verdes em cobertura, o solo foi colocado nos vasos, retirando-se, após, os primeiros $5 \mathrm{~cm}$ de profundidade deste solo, que eram colocados num saco plástico juntamente com as sementes de plantas daninhas, identificadas e pesadas. Em seguida, realizou-se a homogeneização e colocou-se esse solo, agora misturado com as sementes de plantas daninhas, de volta nos vasos, naquela mesma camada, ou seja, nos primeiros $5 \mathrm{~cm}$. A seguir, foram colocados os adubos verdes triturados na superficie dos vasos, nas quantidades anteriormente mencionadas.

$E$ no ensaio onde se utilizou os adubos verdes incorporados ao solo, foi colocado o solo nos vasos, retirando-se, após, os primeiros 5 $\mathrm{cm}$ de profundidade deste solo, que eram colocados num saco plástico juntamente com as sementes de plantas daninhas e com os adubos verdes jâ triturados. Após a homogeneização, colocou-se esse solo, agora misturado com as sementes de plantas daninhas e com os adubos verdes, de volta nos vasos na mesma camada, isto é, nos primeiros $5 \mathrm{~cm}$ de profundidade. Na seqüência, foi feita uma irrigação, sendo que os vasos ficaram submetidos a sistema de irrigação diária, composto por microaspersores, controlados por um "timer", irrigando aproximadamente $5 \mathrm{~mm}$ cada vez que era acionado. A casa-de-vegetação possui um sistema automático de controle de temperatura e umidade relativa, através de ventiladores e a luminosidade era controlada por uma cobertura de sombrite que era, automaticamente, distendida de acordo com a luminosidade incidente.

Para as avaliações, foi realizada a contagem e o corte cuidadoso da parte aérea das plantas daninhas. Em seguida, essas amostras foram colocadas em sacos de papel, devidamente identificados, e levadas ao laboratório para secagem em estufa, a $50^{\circ} \mathrm{C}$, durante 48 horas e pesagem em balança de precisão. 
Os adubos verdes utilizados foram o amendoim forrageiro (Arachis pintoi), crotalária (Crotalária juncea L.), feijão guandu anāo (Cajanus cajan (L.) Millsp.) e as plantas daninhas capim braquiária (Brachiaria decumbens), capim colonião (Panicum maximum) e picão preto (Bidens pilosa L.).

Os parâmetros avaliados durante a condução do experimento, foram os seguintes: duas avaliações de contagem de infestação de plantas daninhas/vaso e duas avaliações de produção de biomassa seca das plantas daninhas (g/vaso), realizadas aos 15 e aos 30 dias após a instalação do experimento.

O delineamento experimental utilizado foi o de blocos casualizados com quatro repetições, em esquema fatorial $3 \times 6 \times 3 \times 2$, sendo três adubos verdes (Arachis pintoi, Crotalaria juncea e Cajanus cajan), seis tratamentos (quantidades de adubo verde: $0 \mathrm{x}, 0,5 \mathrm{x}, 1 \mathrm{x}, 2 \mathrm{x}$, $4 \mathrm{x}$ e $8 \mathrm{x}$ ), três plantas daninhas ( $B$. decumbens, $P$. maximum e $B$. pilosa) e duas profundidades de incorporação do adubo verde (na superfície do solo e a $5 \mathrm{~cm}$ de profundidade), conforme pode ser observado na Tabela 6.1 .

A Análise de Variância dos resultados foi realizada com o auxilio do Sistema de Análise Estatística - SANEST, e as médias submetidas ao teste de Tukey para 0,05\% de probabilidade, sendo que foi necessária a aplicação de regressões polinomiais lineares, quadráticas e cúbicas para se obter os resultados das interações significativas. 
Tabela 6.1. Descrição dos fatores utilizados no delineamento do esquema fatorial $3 \times 6 \times 3 \times 2$. Experimento de casa-devegetação. Piracicaba, 2000 - USP/ESALQ.

\section{Fatores}

\section{Descrição}

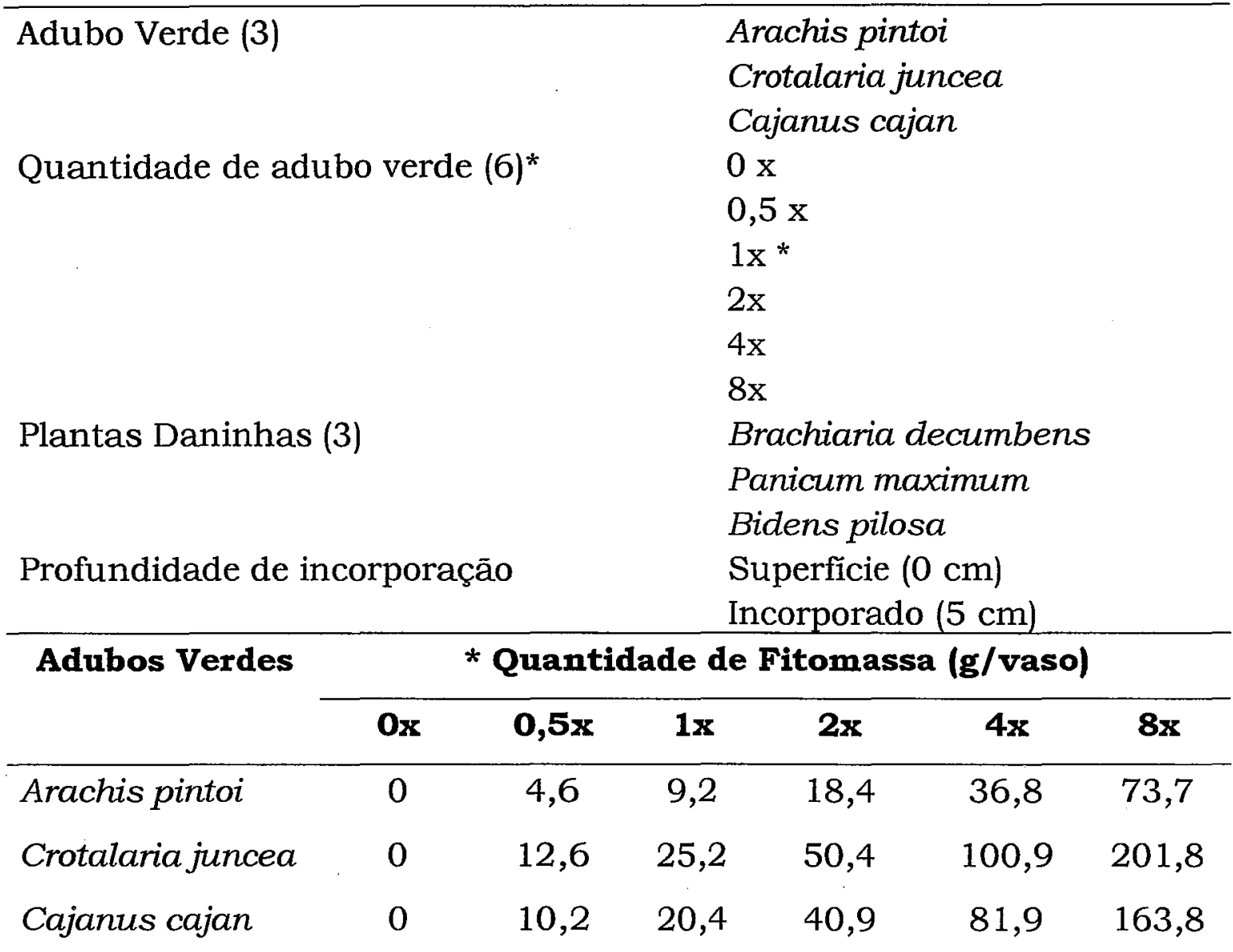

* Para o Arachis pintoi a produtividade no campo, ou seja, $1 \mathrm{x}=6,45$ ton/ha, para Crotalaria juncea $1 \mathrm{x}=17,64$ ton/ha e Cajanus cajan $1 \mathrm{x}=14,32$ ton/ha.

\subsection{Resultados e Discussão}

Nas Figuras 6.1 a 6.4, estão apresentadas as médias de densidade e de produção de biomassa seca das plantas daninhas, da primeira e da segunda avaliação, a partir de amostras retiradas dos diversos tratamentos aplicados no experimento na superficie do solo. É 
importante salientar que, quando se utilizou as leguminosas na superfície do solo, não houve diferenças significativas entre eles, isto é, todos os três adubos verdes testados causaram os mesmos efeitos na redução da densidade e de produção de biomassa seca das plantas daninhas em estudo. Assim, nos gráficos estão representados os dados médios dos três adubos verdes em conjunto (Figuras 6.1 a 6.4).

Analisando-se as Figuras 6.1 e 6.3 , observa-se interações entre a quantidade de adubo verde utilizada e a redução da densidade e da produção de biomassa seca das plantas daninhas, pois, na medida em que se aumentou a quantidade de fitomassa do adubo verde, ocorreram, de forma geral, reduções nestes dois parâmetros de avaliação. Na Figura 6.3, verifica-se, ainda, que na quantidade $4 x$, houve um estímulo na produção de biomassa seca de capim colonião causada, provavelmente, pelas interferências positivas da alelopatia.

Nas Figuras 6.2 e 6.4, está representada a curva de resposta apenas da planta daninha picão preto, pois as demais plantas daninhas (capim braquiária e capim colonião) não sofreram reduções significativas tanto na densidade quanto na fitomassa seca em função das quantidades de adubos verdes.

Em relação ao ensaio realizado utilizando-se os adubos verdes incorporados ao solo, nas Figuras 6.5 a 6.12, estão apresentadas as médias de densidade e de produção de biomassa seca das plantas daninhas, da primeira e da segunda avaliação, a partir de amostras retiradas dos diversos tratamentos aplicados no experimento. Neste caso, na primeira avaliação dos dois parâmetros, houve diferenças significativas entre eles, isto é, todos os três adubos verdes testados causaram diferentes efeitos na redução da densidade e de produção de biomassa seca das plantas daninhas em estudo. Já na segunda avaliação, houve diferença significativa entre os adubos verdes apenas em relação ao picão preto. 


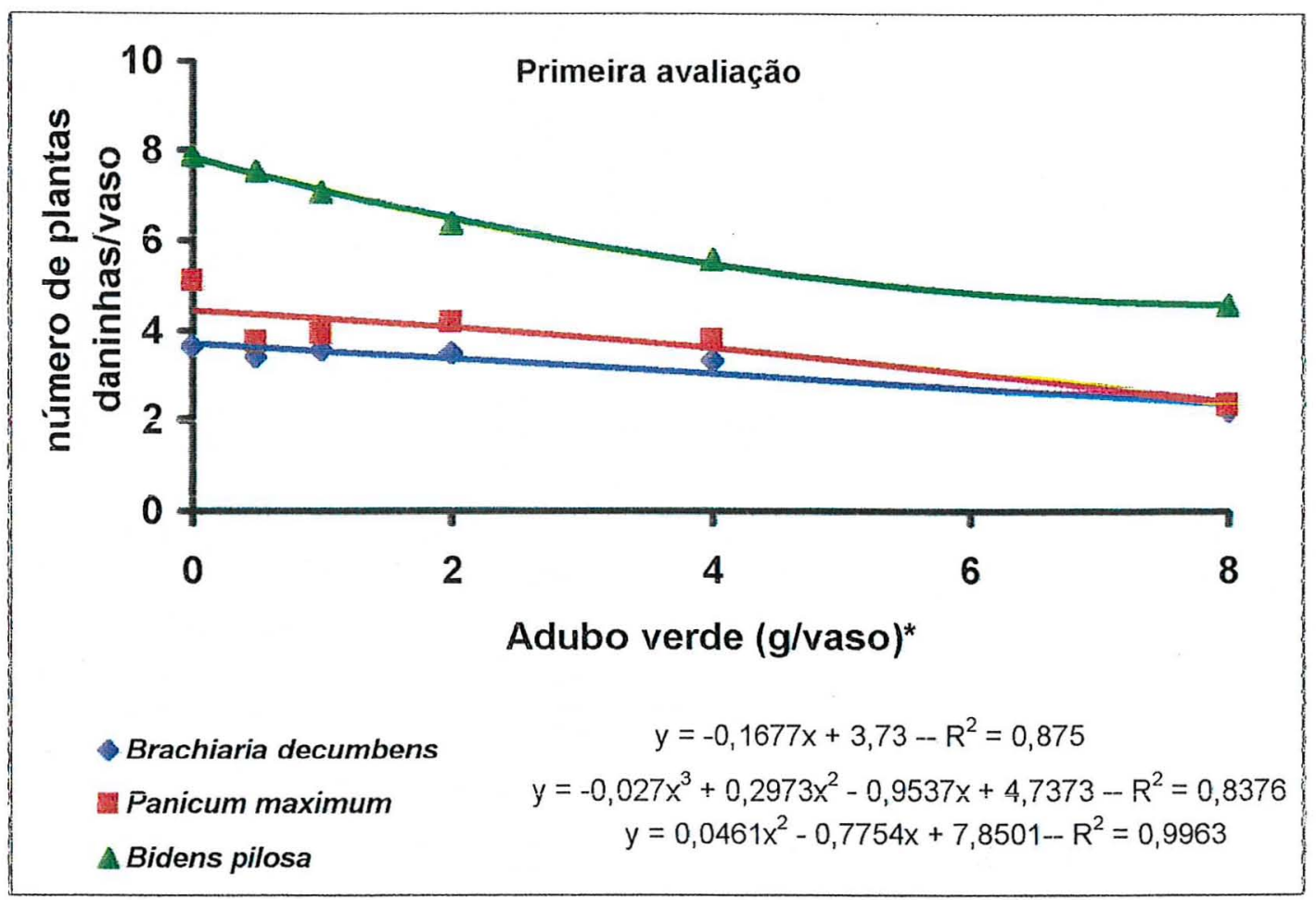

Figura 6.1. Gráfico do número de plantas daninhas por vaso em função de adubos verdes aplicados em cobertura no solo. * vide Tabela 6.1

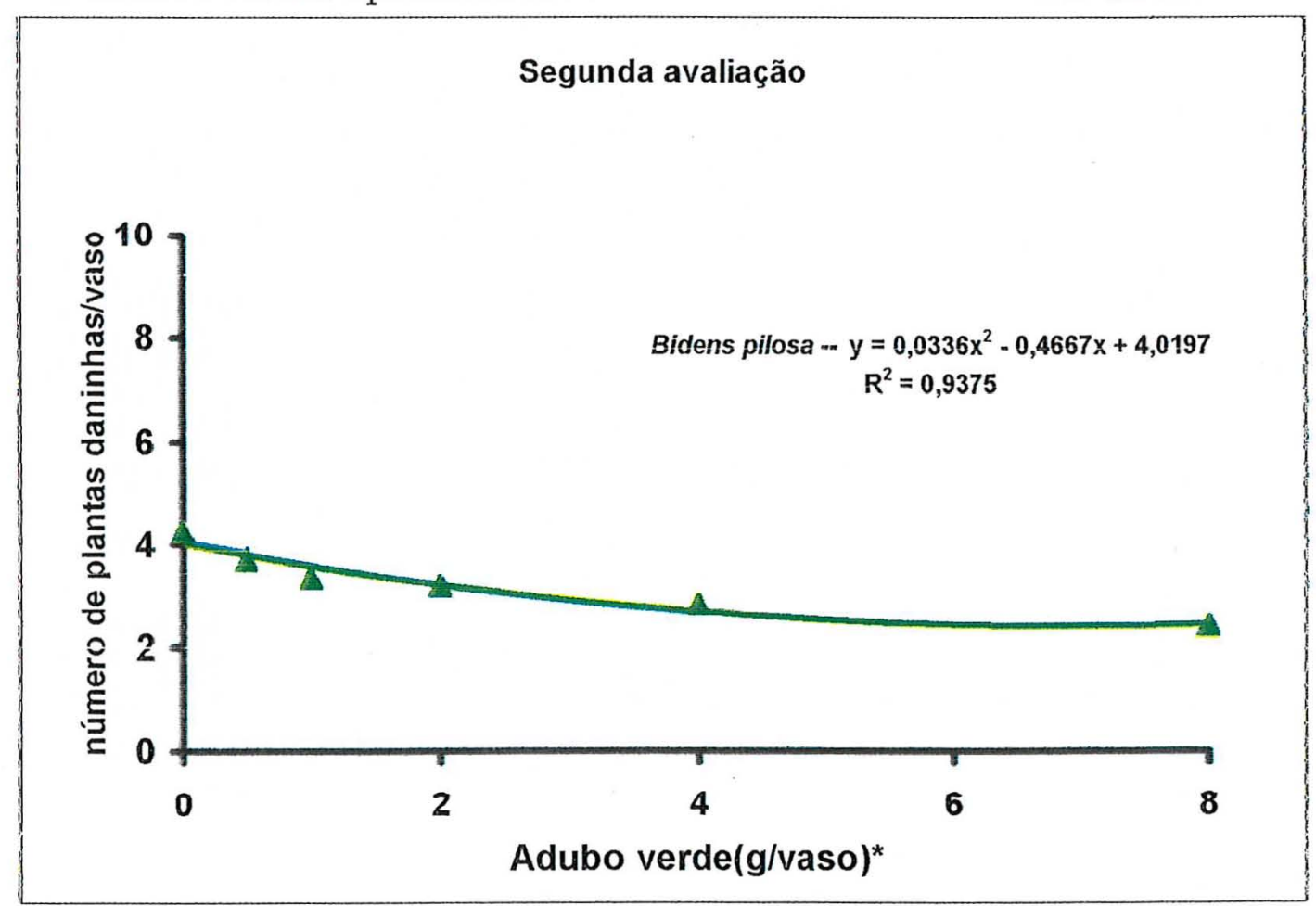

Figura 6.2. Gráfico do número de plantas daninhas por vaso em função de adubos verdes aplicados em cobertura no solo. * vide Tabela 6.1 


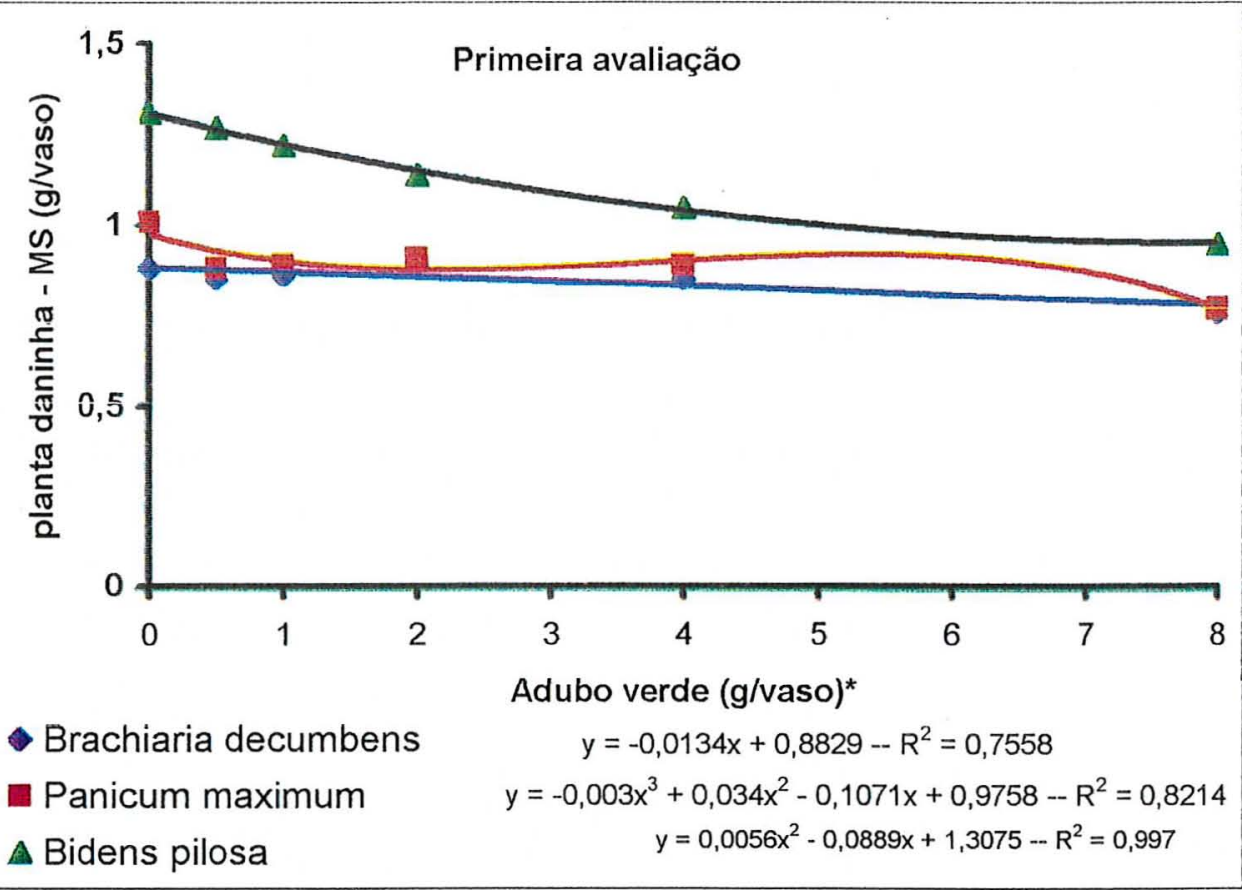

Figura 6.3. Gráfico da biomassa seca de plantas daninhas por vaso em função de adubos verdes aplicados em cobertura no solo. * vide Tabela 6.1

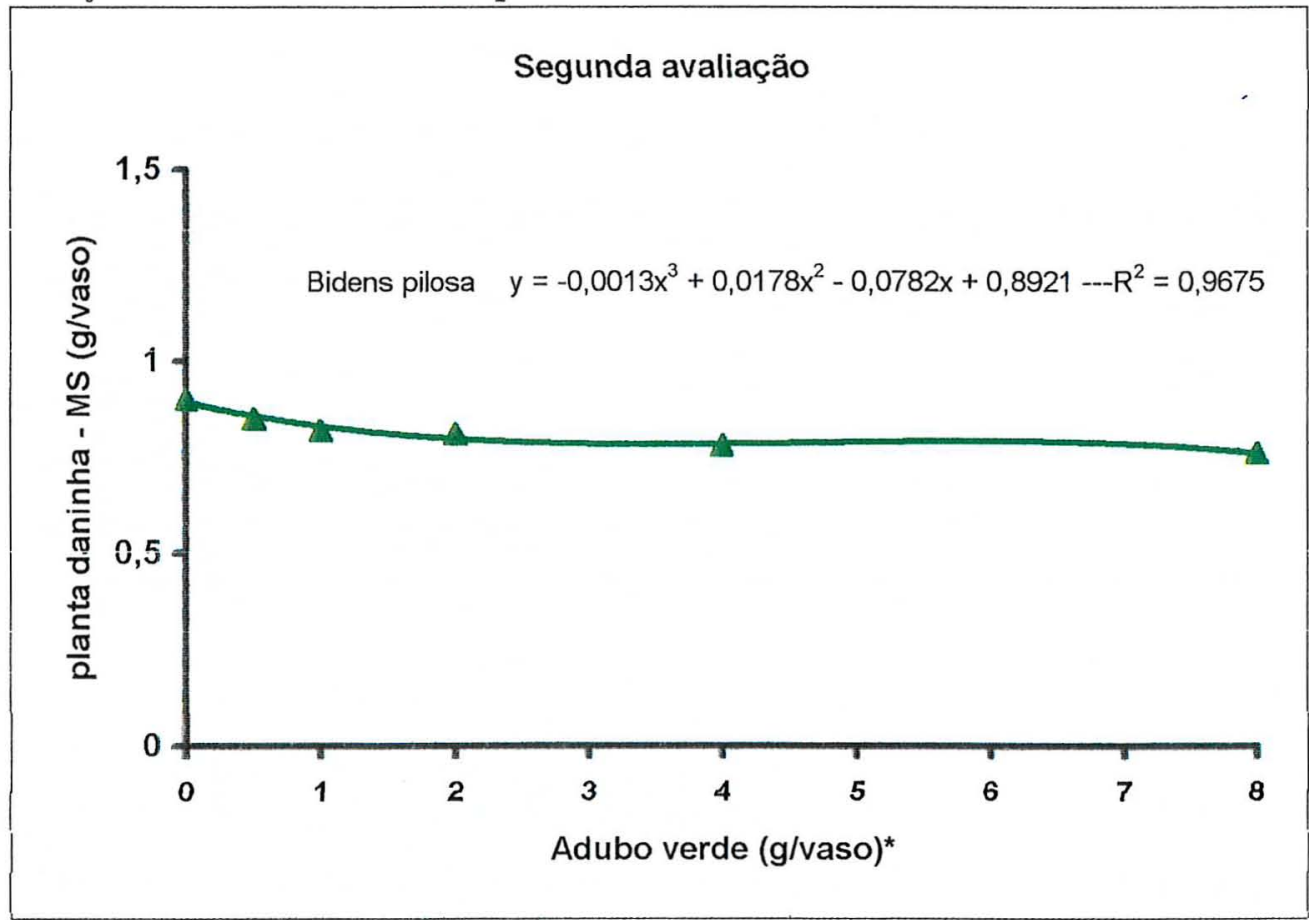

Figura 6.4. Gráfico da biomassa seca de plantas daninhas por vaso em função de adubos verdes aplicados em cobertura no solo. * vide Tabela 6.1 
Analisando-se as Figuras 6.5 a 6.8 , primeira e segunda avaliação de densidade das plantas daninhas, verifica-se que, com o aumento da quantidade de fitomassa, houve redução da densidade das plantas daninhas e que os três adubos verdes reduziram com eficiência a densidade das três espécies de plantas daninhas estudadas. Na Figura 6.6, observa-se que, na quantidade $4 \mathrm{x}$, a Crotalaria juncea aumentou a densidade de picão preto, sendo que esta foi novamente reduzida na quantidade $8 x$. E, na Figura 6.8, nota-se que não houve interações significativas entre os adubos verdes e que a interação, desses para com as plantas daninhas, só ocorreu para picão preto.

Analisando-se as Figuras 6.9 a 6.12 , primeira e segunda avaliação de produção de biomassa seca das plantas daninhas, nota-se que, de acordo com o aumento da quantidade de fitomassa dos adubos verdes, verificou-se redução da produção de biomassa seca das plantas daninhas e que os três adubos verdes reduziram com eficiência a produção de biomassa seca de capim braquiária e capim colonião e, em maior intensidade, a produção de biomassa seca de picão preto. Nas Figuras 6.10 e 6.11, verifica-se que, na quantidade $4 x$, a Crotalaria juncea e o Cajanus cajan estimularam a produção de biomassa seca do picão preto, sendo que esta voltou a cair na quantidade $8 x$. E, na Figura 6.12 , observa-se que não ocorreu interações significativas entre os adubos verdes e que a interação, desses para com as plantas daninhas, só ocorreu para picão preto, de forma que, nạ medida em que a quantidade de fitomassa dos adubos verdes foi sendo aumentada, a produção de biomassa seca do picão preto foi se reduzindo, demonstrando a correlação linear existente entre a quantidade de fitomassa e a redução da infestação por plantas daninhas, comprovada por Almeida e Rodrigues (1985). 


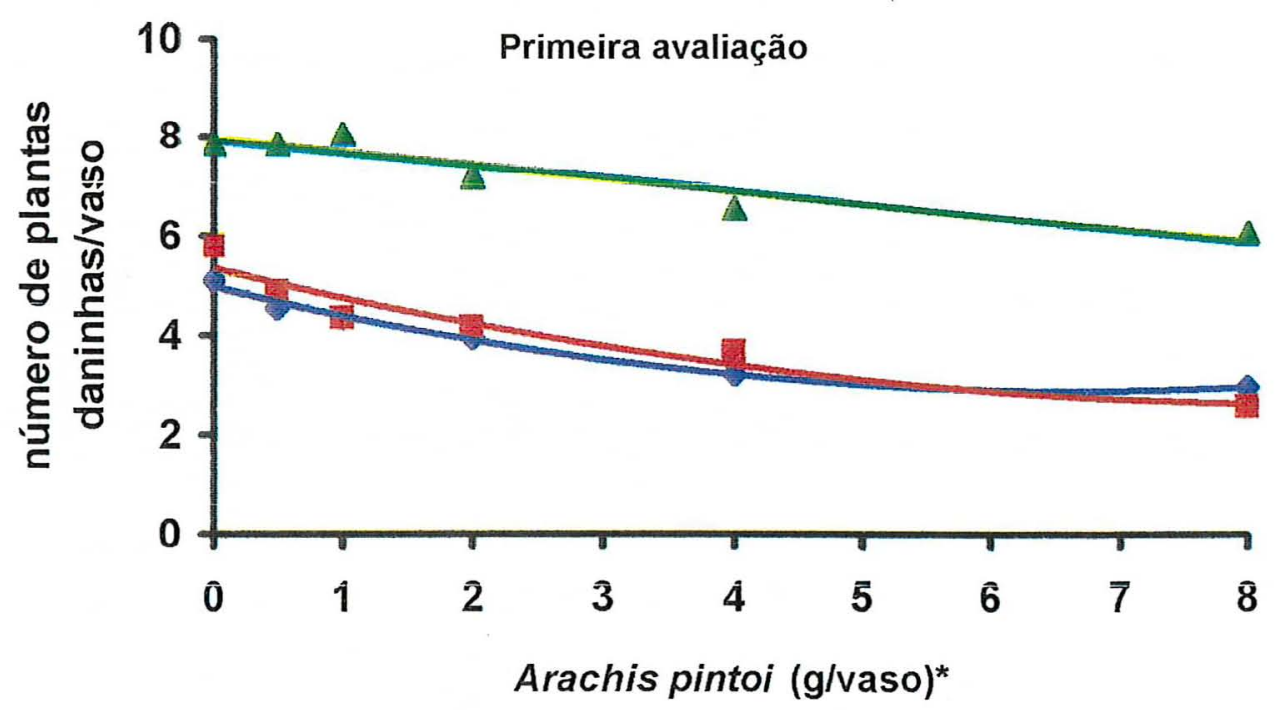

- Brachiaria decumbens

$y=0,047 x^{2}-0,6256 x+4,9718-R^{2}=0,9905$

Panicum maximum

$y=0,036 x^{2}-0,6275 x+5,3531-R^{2}=0,9219$

Bidens pilosa

$y=-0,2542 x+7,9183-R^{2}=0,8892$

Figura 6.5. Gráfico do número de plantas daninhas por vaso em função do adubo verde incorporado no solo. ${ }^{*}$ vide Tabela 6.1

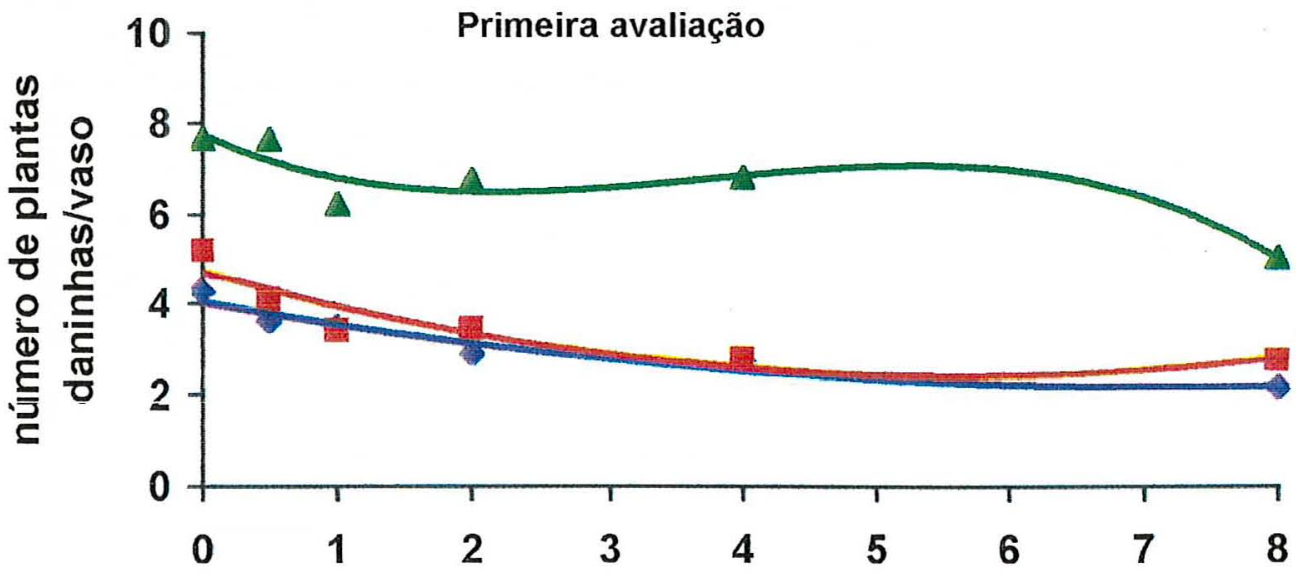

Crotalaria juncea (g/vaso)*

- Brachiaria decumbens

罾 Panicum maximum

$$
\begin{gathered}
y=0,036 x^{2}-0,5173 x+4,0285-R^{2}=0,929 \\
y=0,0725 x^{2}-0,8177 x+4,7105-R^{2}=0,8518
\end{gathered}
$$

B Bidens pilosa

$$
y=-0,0387 x^{3}+0,4355 x^{2}-1,3469 x+7,7664-R^{2}=0,8705
$$

Figura 6.6. Gräfico do número de plantas daninhas por vaso em funçāo do adubo verde incorporado no solo. ${ }^{*}$ vide Tabela 6.1 


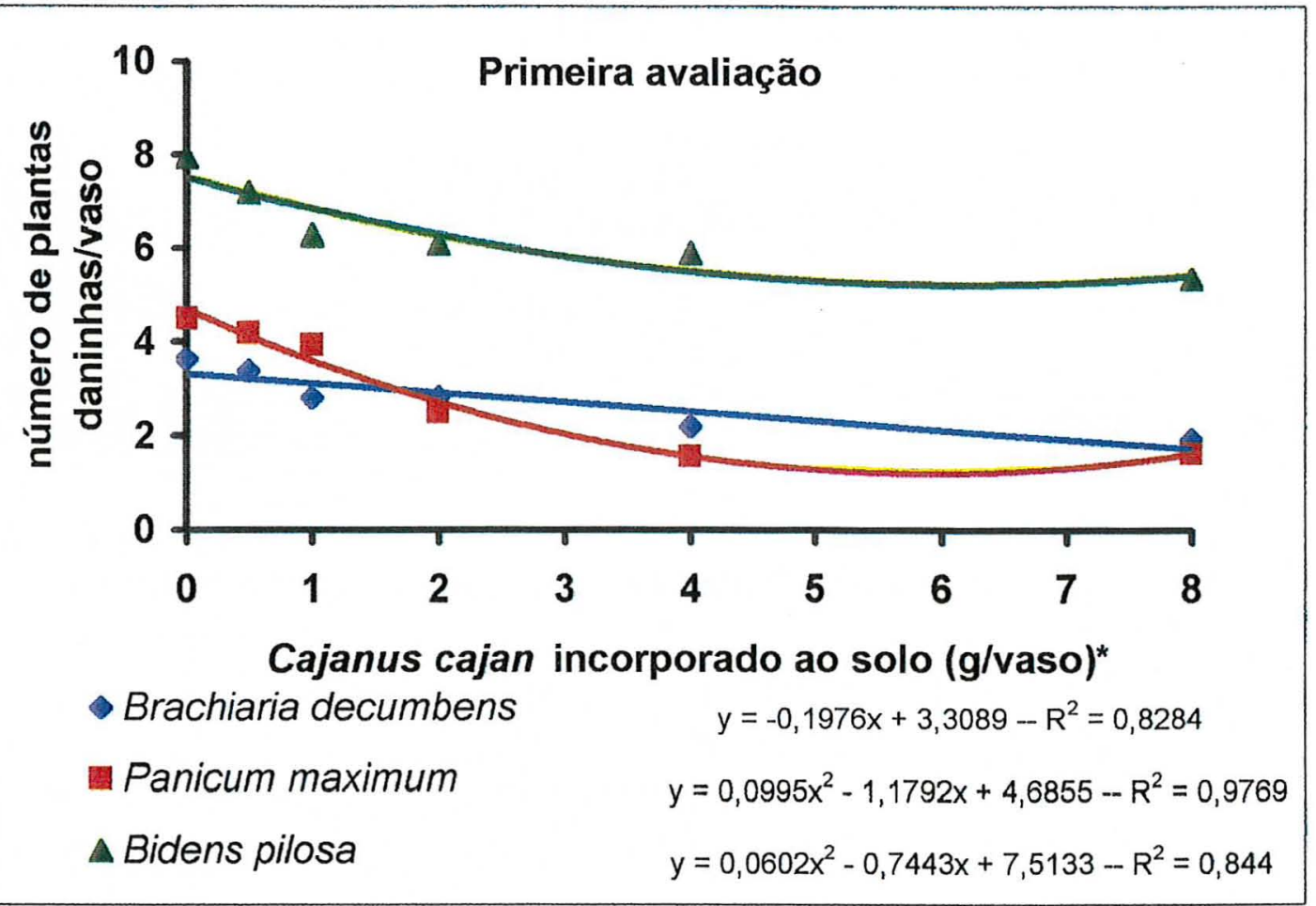

Figura 6.7. Gráfico do número de plantas daninhas por vaso em função do adubo verde incorporado no solo. * vide Tabela 6.1

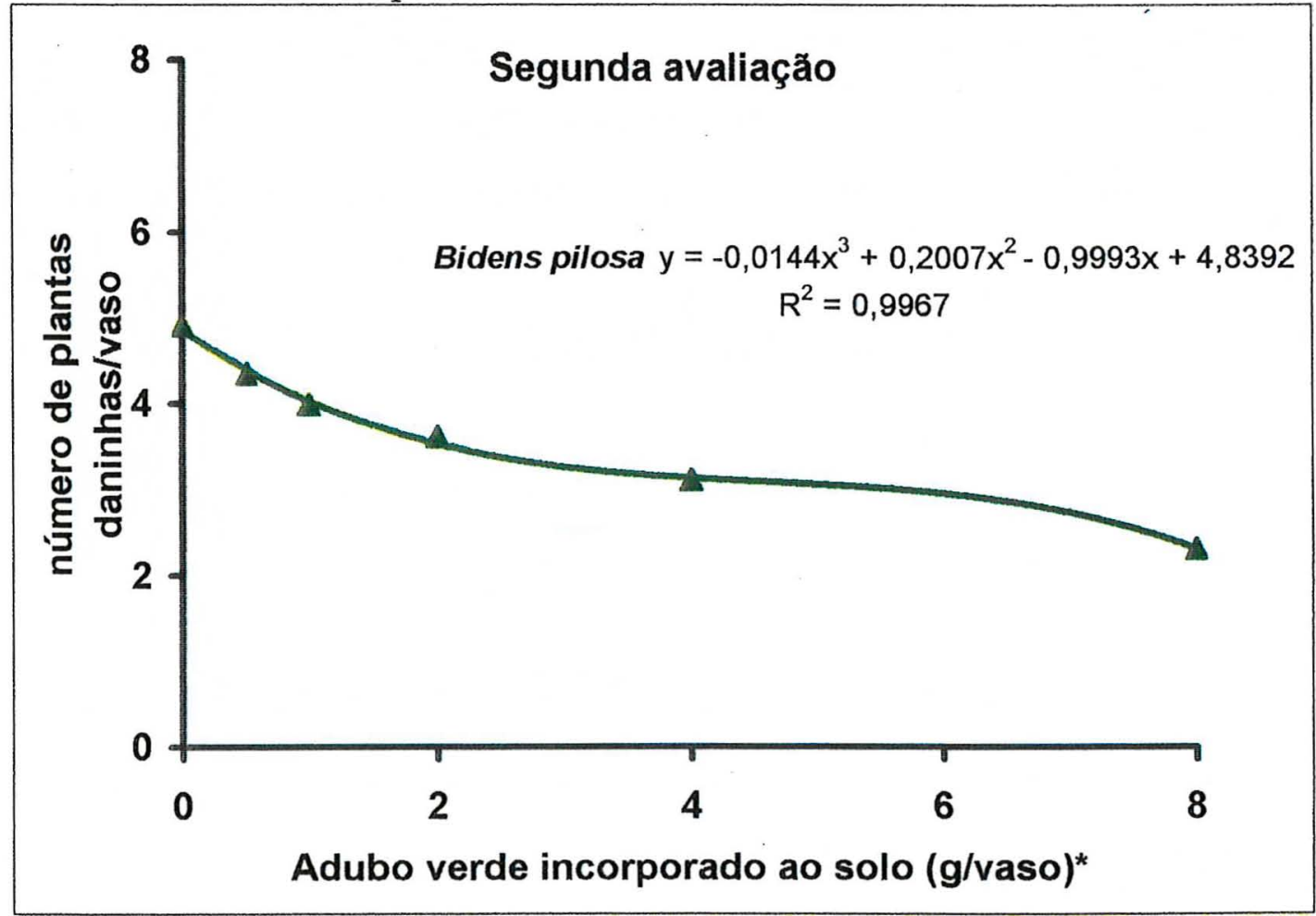

Figura 6.8. Gráfico do número de plantas daninhas por vaso em função dos adubos verdes incorporados no solo. * vide Tabela 6.1 


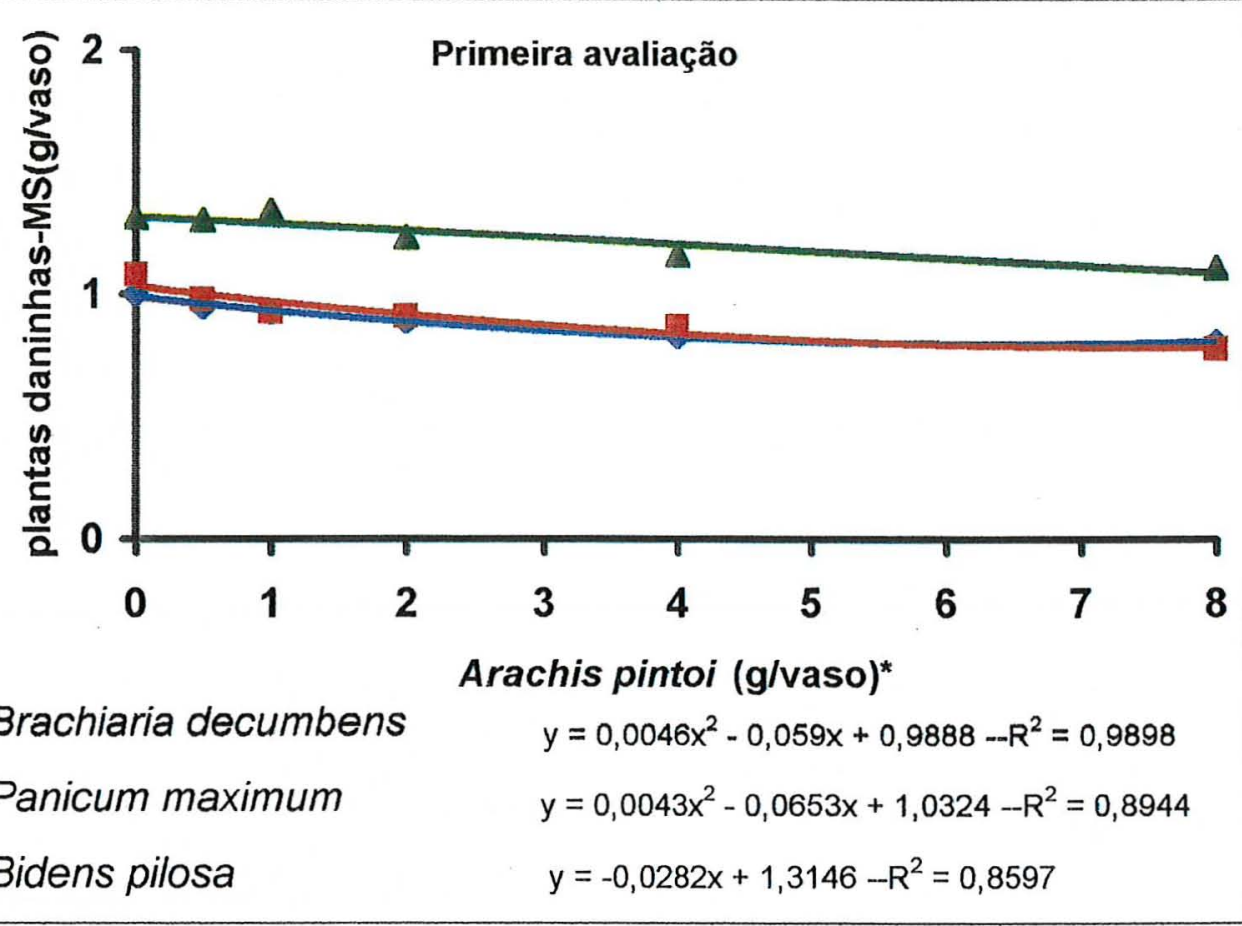

Figura 6.9. Gráfico de produção de biomassa seca por vaso em função do adubo verde incorporado no solo. * vide Tabela 6.1

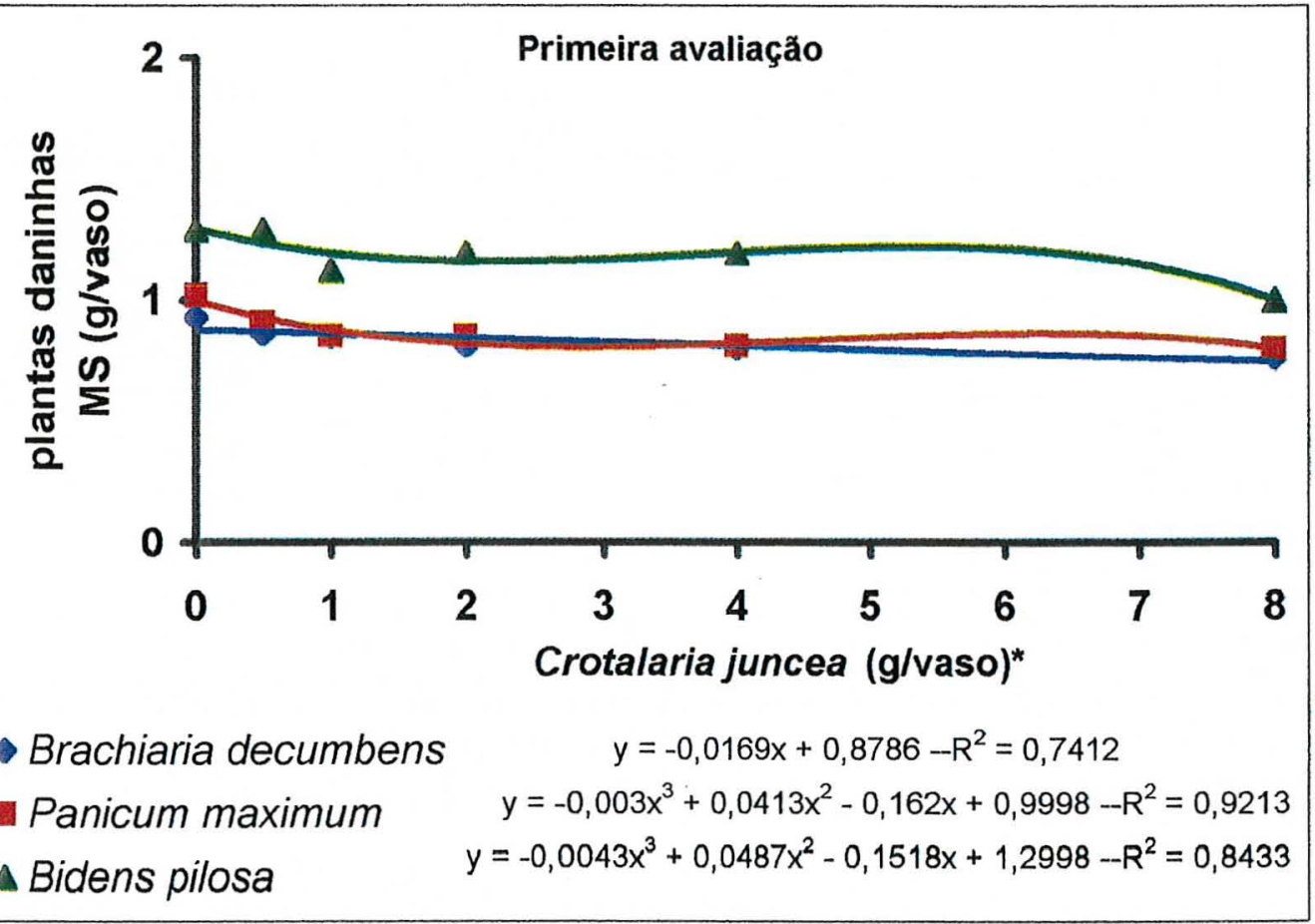

Figura 6.10. Gräfico de produção de biomassa seca por vaso em função do adubo verde incorporado no solo. * vide Tabela 6.1 


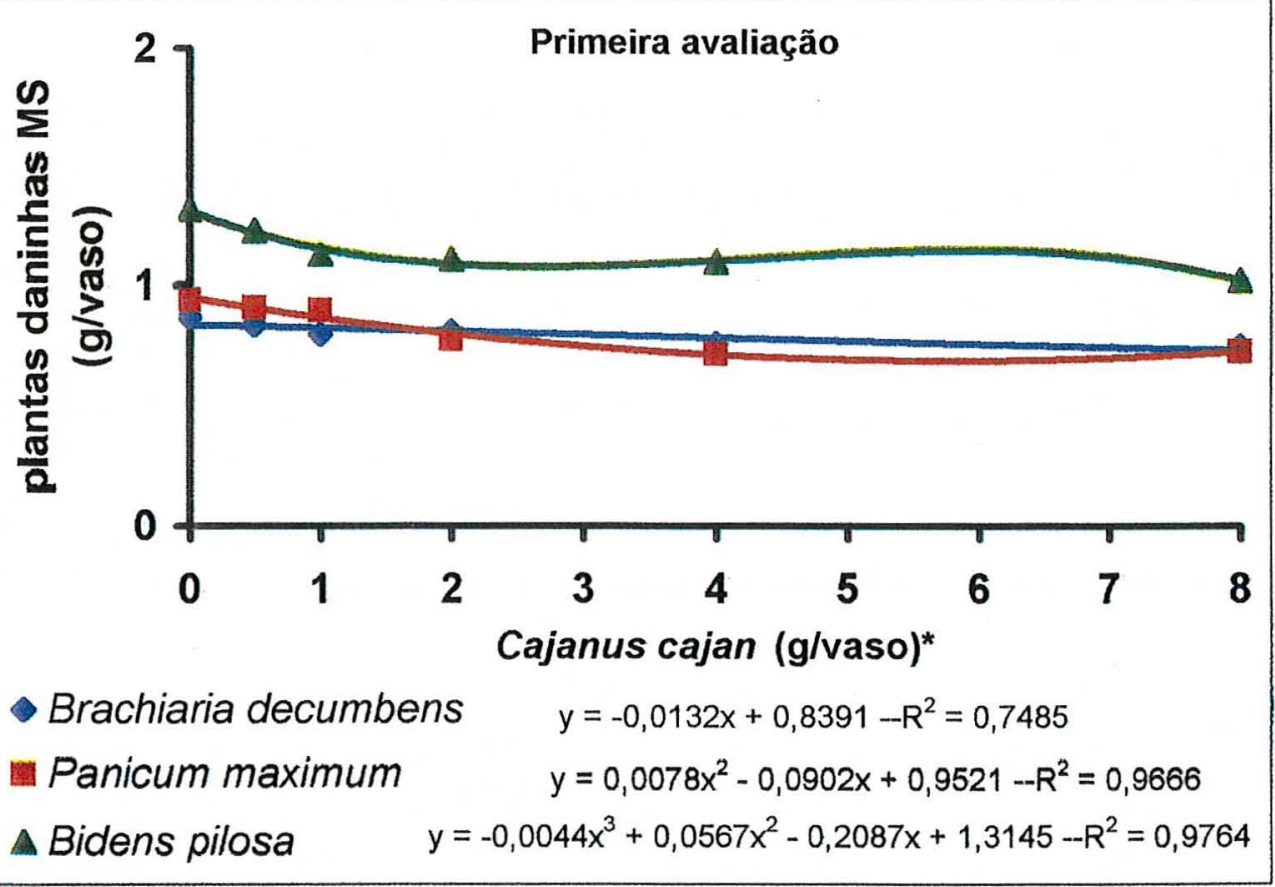

Figura 6.11. Gráfico de produção de biomassa seca por vaso em função do adubo verde incorporado no solo. * vide Tabela 6.1

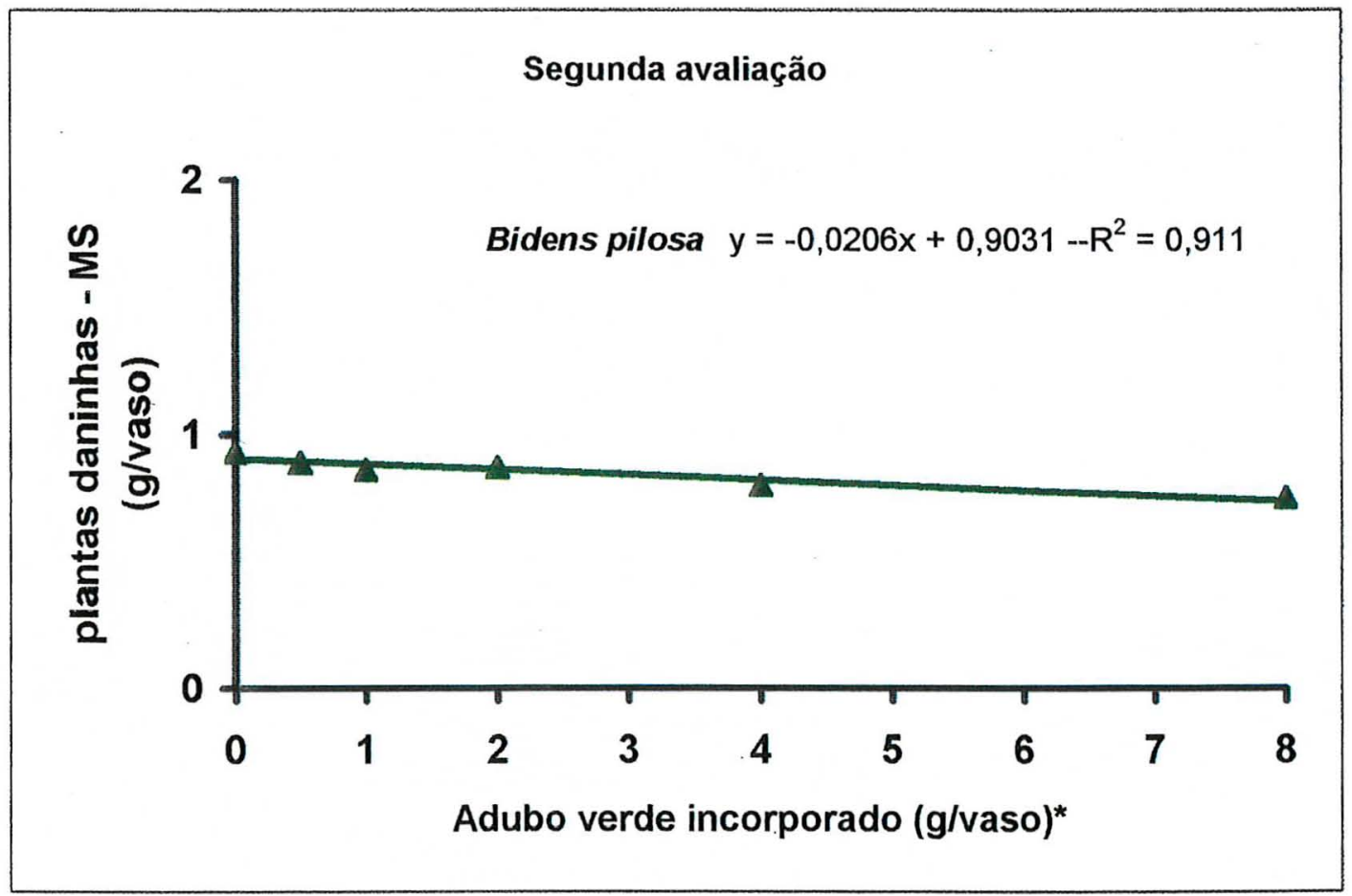

Figura 6.12. Gráfico de produção de biomassa seca por vaso em função dos adubos verdes incorporados no solo. * vide Tabela 6.1 
Nas Figuras 6.13 a 6.18 , estão apresentadas as médias de densidade e de produção de biomassa seca das plantas daninhas, a partir de amostras retiradas dos tratamentos aplicados no ensaio. Neste caso, estão sendo comparados os resultados obtidos pela utilização da quantidade de fitomassa de cada adubo verde em cada planta daninha. Nos dois parâmetros de avaliação, ocorreram diferenças significativas, ou seja, as três leguminosas utilizadas provocaram efeitos distintos na redução da densidade e de produção de biomassa seca das plantas daninhas em estudo.

Observando-se a Figura 6.13, verifica-se que os três adubos verdes, reduziram a germinação de picão preto, porém, na quantidade $4 \mathrm{x}$, tanto Crotalaria juncea, como Cajanus cajan, estimularam a germinação deste. Entretanto, a germinação caiu novamente quando a quantidade $8 \mathrm{x}$ foi empregada.

Analisando-se as Figuras 6.14 e 6.15 , nota-se que os três adubos verdes foram eficientes na inibição da germinação de capim braquiária e de capim colonião, sendo Cajanus cajan o mais eficiente e Arachis pintoi o menos eficiente. Ainda na Figura 6.15, pode-se notar que, tanto Crotalaria juncea, como Cajanus cajan, na quantidade $4 \mathrm{x}$, propiciaram um pequeno aumento na germinação de capim colonião, a qual foi aumentando até a quantidade 8x. Este aumento na germinação de capim coloniāo pode ser explicado pelo efeito estimulante da alelopatia, demonstrando que quanto maior for a quantidade desta fitomassa, maior é a concentração e a diversidade de aleloquímicos liberados no solo (Almeida, 1988). 


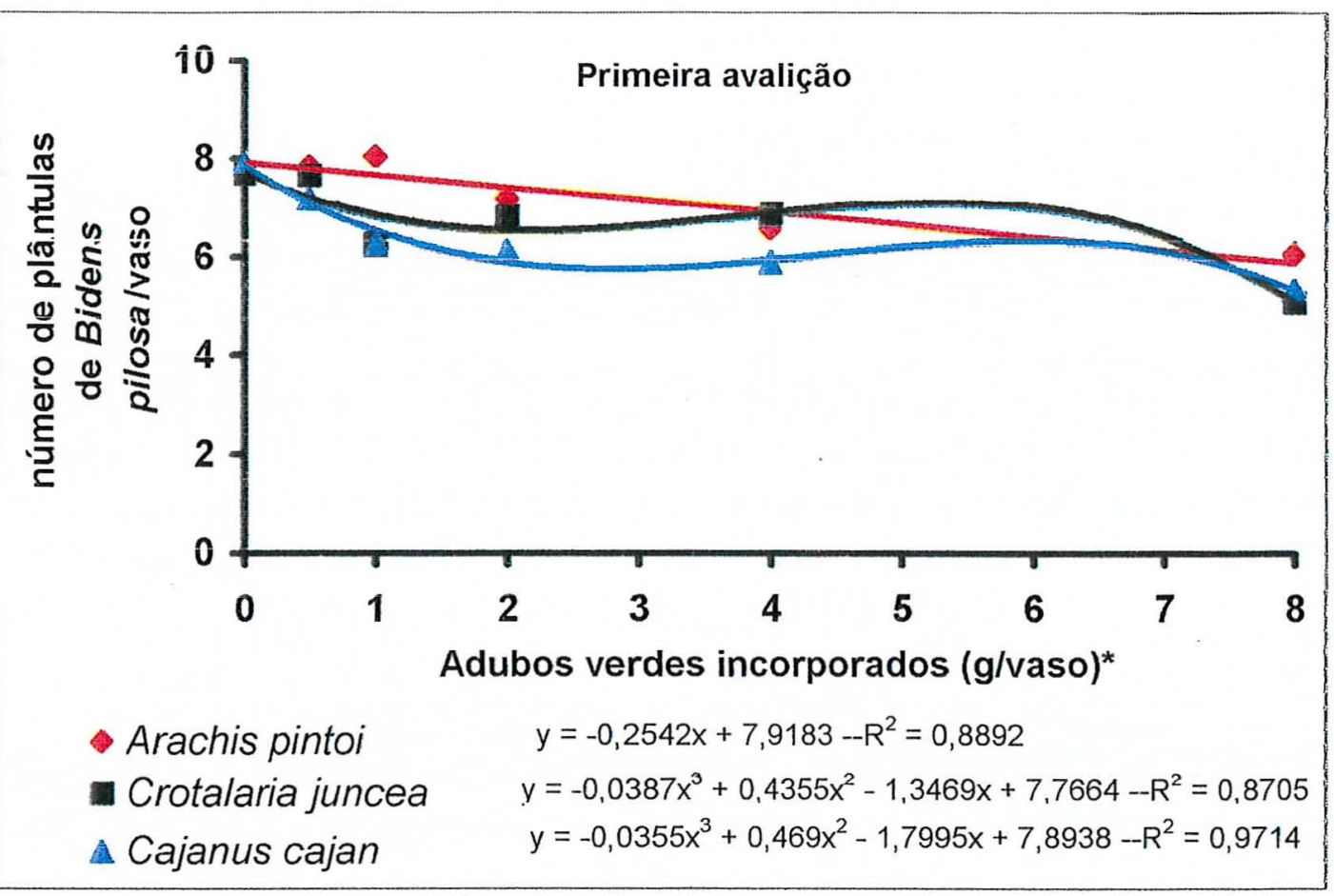

Figura 6.13. Gráfico do número de plantas daninhas por vaso em função dos adubos verdes incorporados no solo. * vide Tabela 6.1

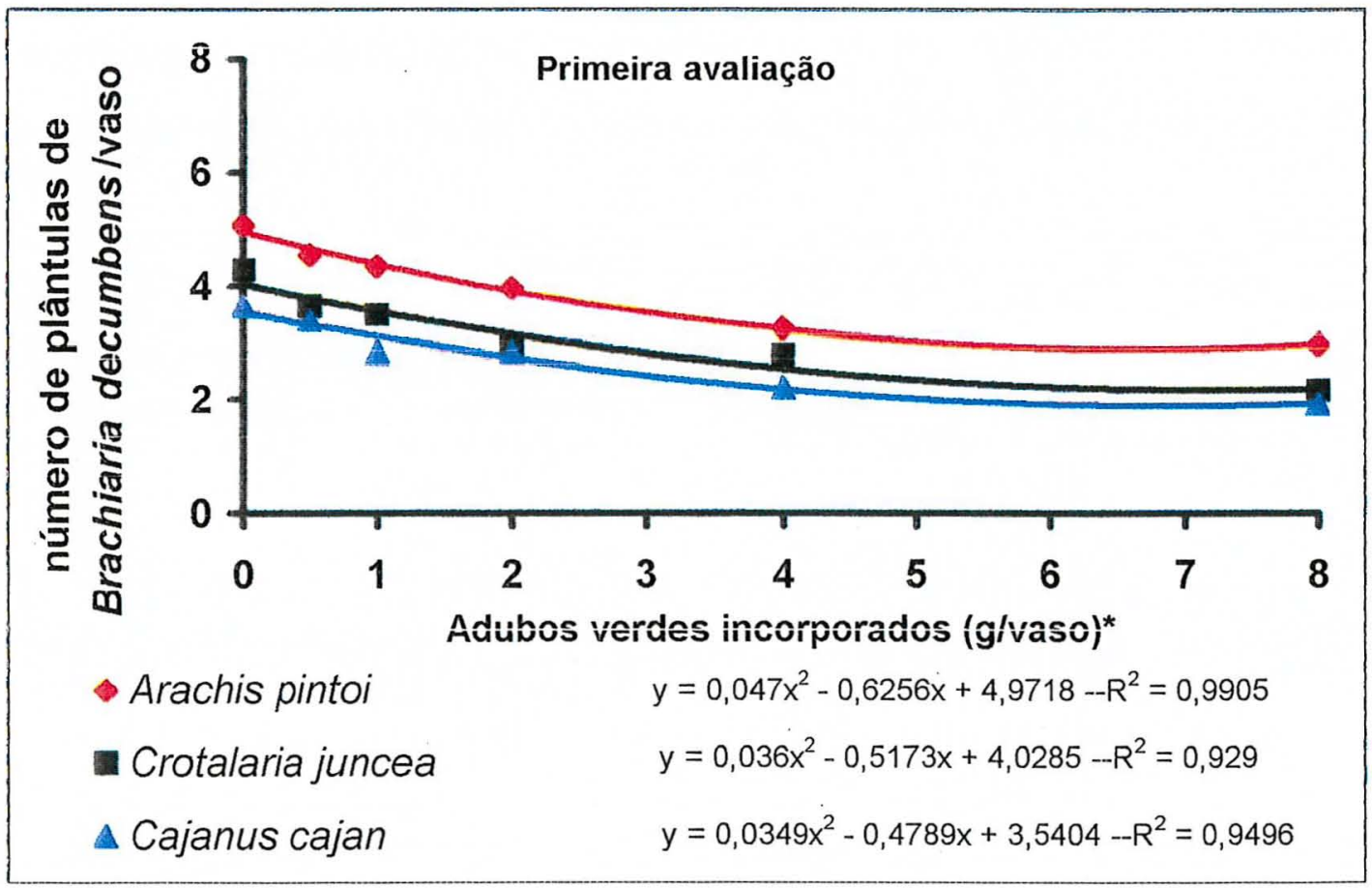

Figura 6.14. Gráfico do número de plantas daninhas por vaso em função dos adubos verdes incorporados no solo. * vide Tabela 6.1 


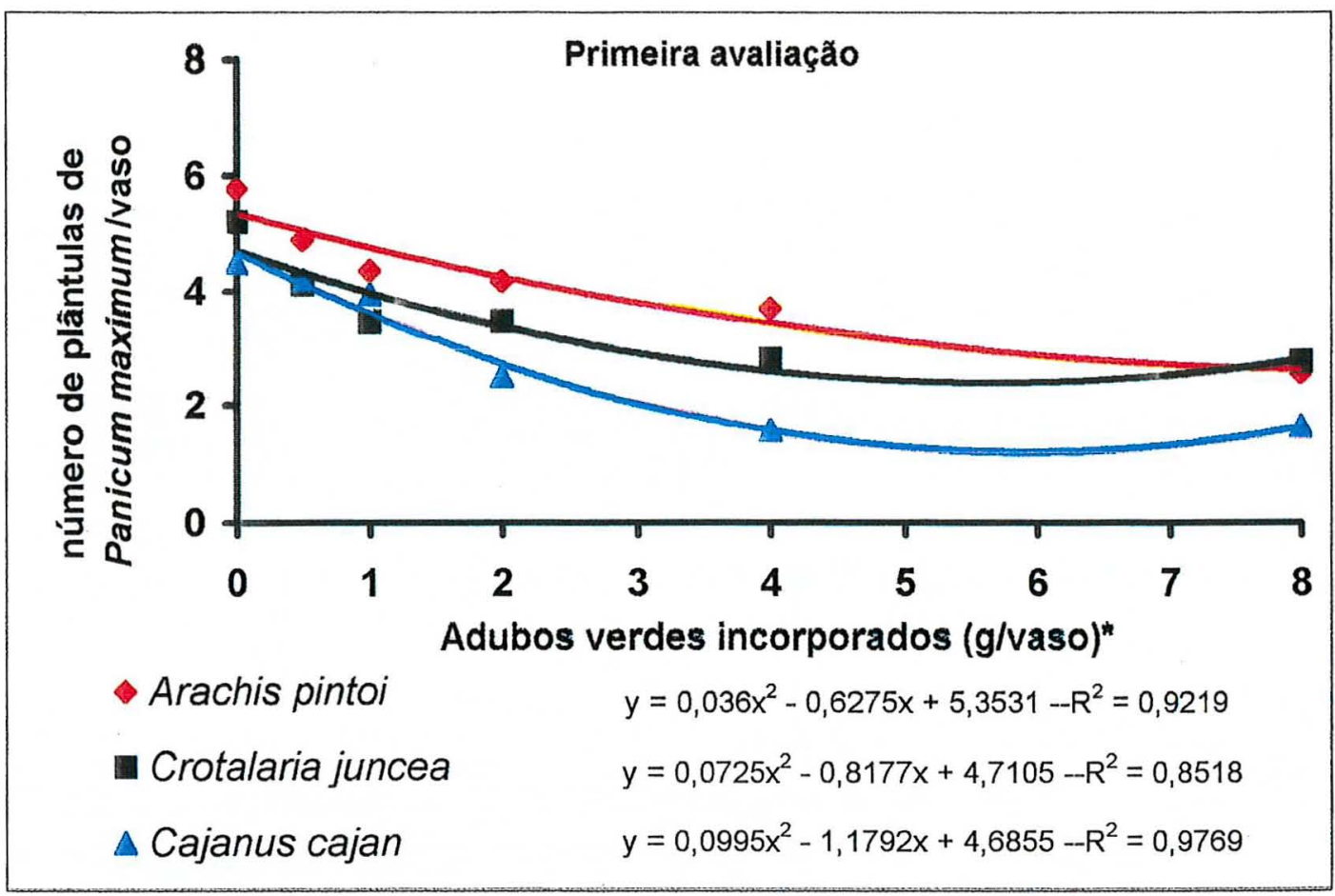

Figura 6.15. Gräfico do número de plantas daninhas por vaso em função dos adubos verdes incorporados no solo. * vide Tabela 6.1

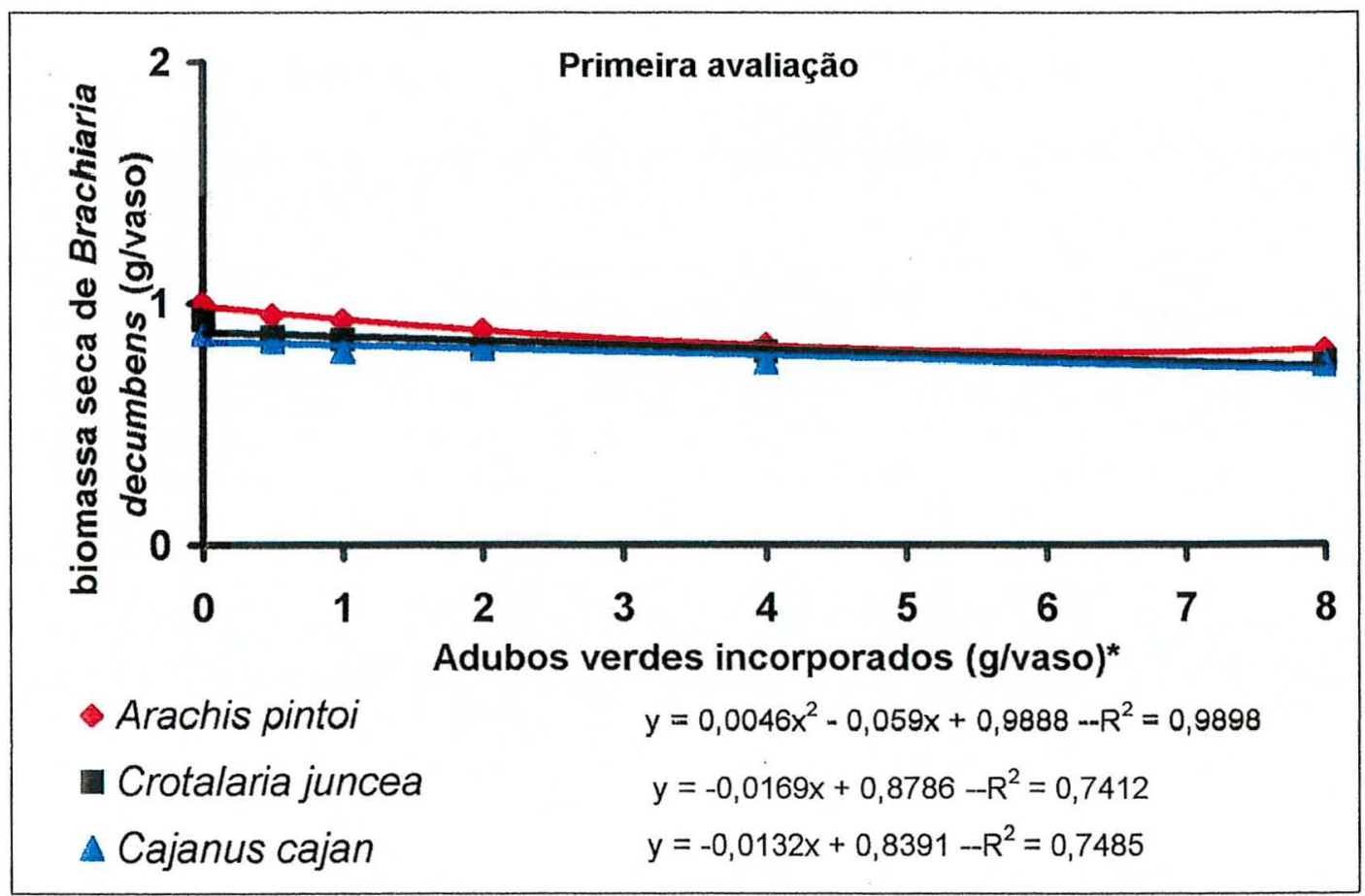

Figura 6.16. Gráfico de produção de biomassa seca por vaso em função dos adubos verdes incorporados no solo. * vide Tabela 6.1 


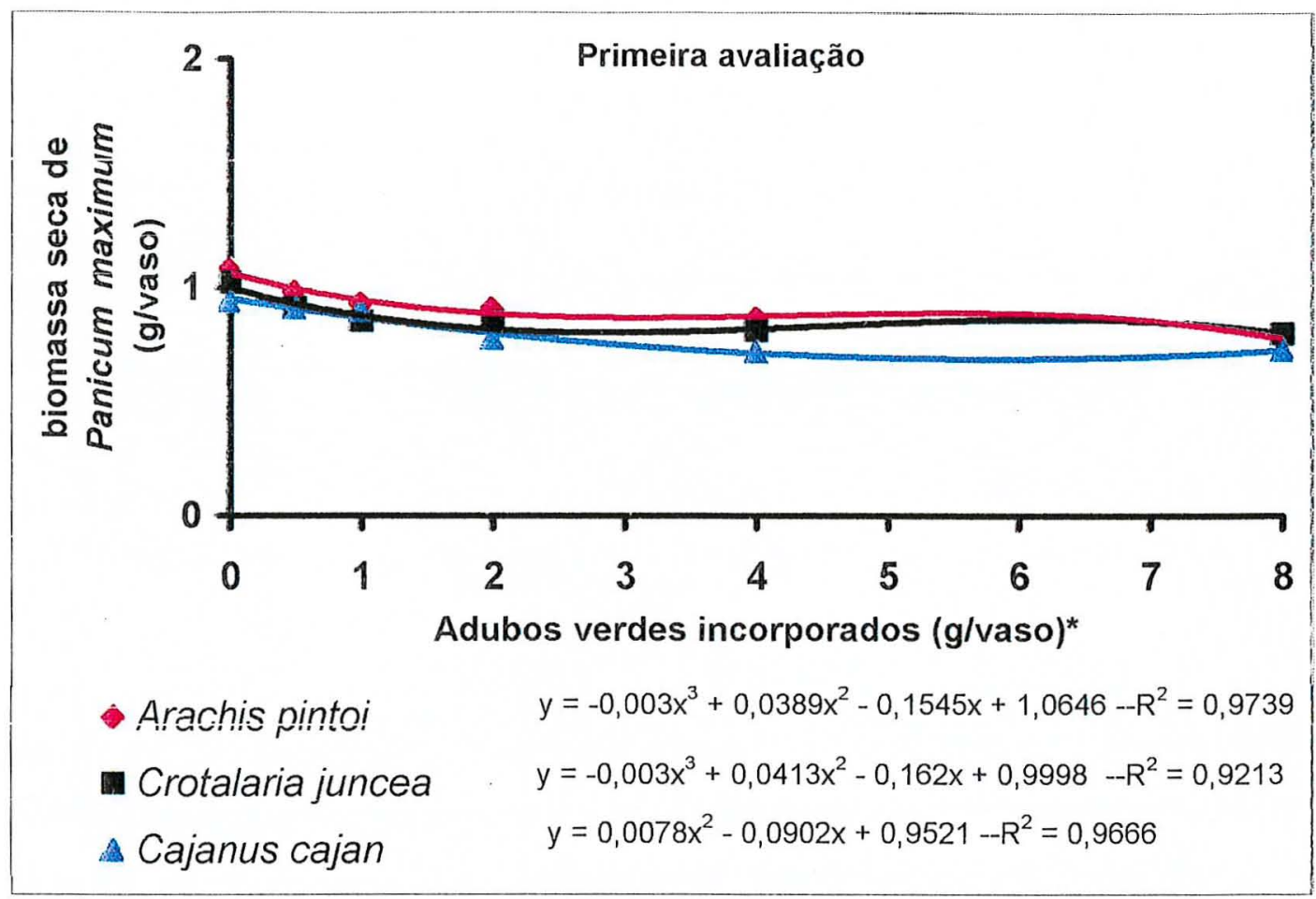

Figura 6.17. Gráfico de produção de biomassa seca por vaso em função dos adubos verdes incorporados no solo. * vide Tabela 6.1

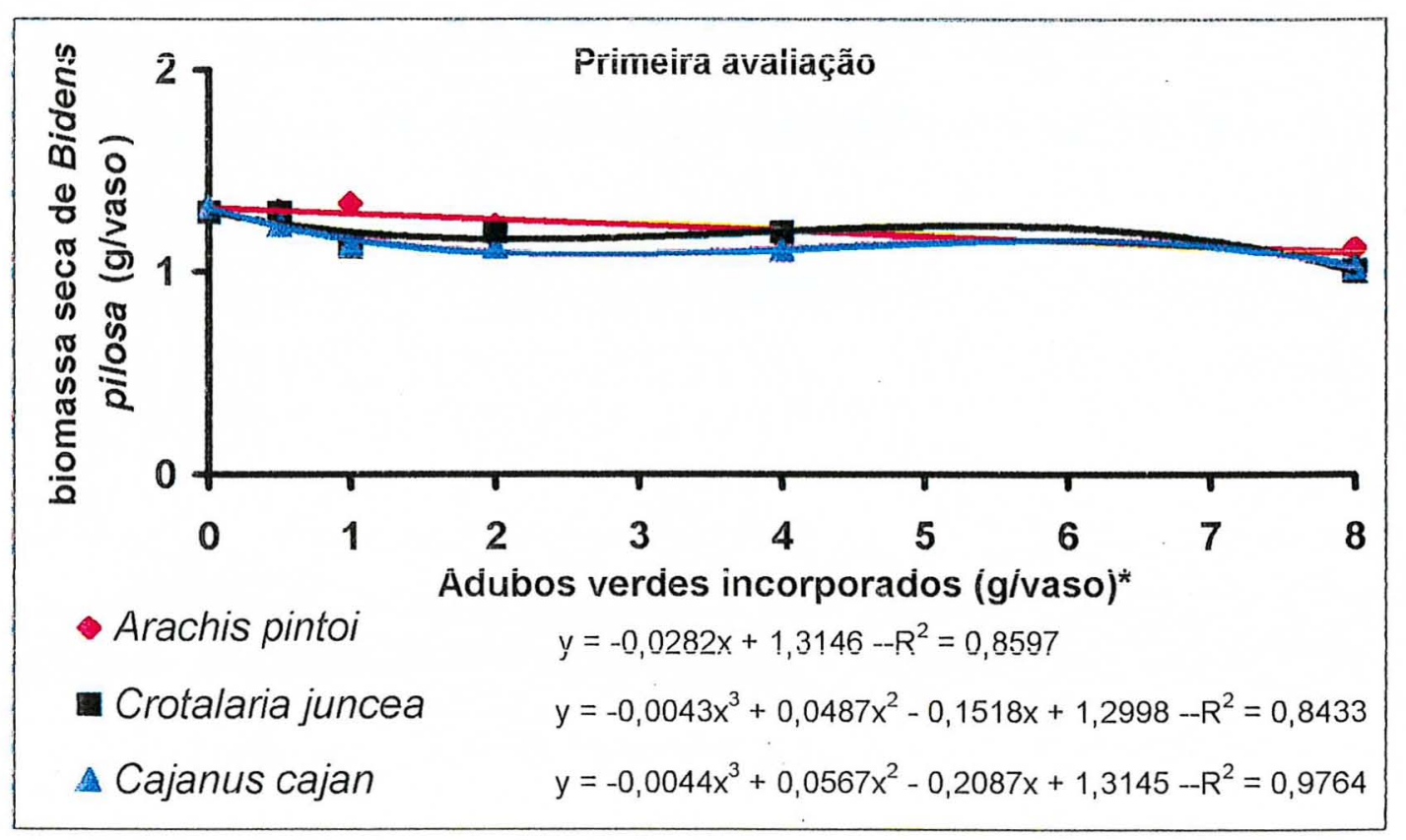

Figura 6.18. Gráfico de produção de biomassa seca por vaso em função dos adubos verdes incorporados no solo. * vide Tabela 6.1 
Observando-se a Figura 6.16, verifica-se uma correlação linear entre as quantidades de fitomassa utilizada e a produção de biomassa seca de capim braquiária, em relação aos três adubos verdes. Na Figura 6.17, nota-se relação direta entre quantidade de fitomassa e produção de biomassa seca de capim colonião, quando se utiliza Cajanus cajan. Entretanto, Arachis pintoi e Crotalaria juncea, na quantidade $4 x$, proporcionaram um pequeno aumento nesta produção.

Na Figura 6.18, observa-se que, Arachis pintoi reduziu linearmente a produção de biomassa seca de picão preto, conforme sua quantidade de fitomassa aumentava e que, tanto Crotalaria juncea quanto Cajanus cajan, na dose $4 \mathrm{x}$, ocasionaram um leve estimulo nesta produçāo, que voltou a cair quando se empregou a quantidade $8 \mathrm{x}$,

\subsection{Conclusões}

a) Os três adubos verdes testados reduziram a germinação e produção de biomassa seca das plantas daninhas em estudo.

b) O efeito das diferentes fitomassas é maior na planta daninha Bidens pilosa.

c) Brachiaria decumbens e Panicum maximum são influenciados de maneira semelhante pelos diferentes tipos de fitomassa.

d) O adubo verde Cajanus cajan é o mais eficiente na redução da germinação e produção de biomassa seca de todas as plantas daninhas estudadas. 
e) O adubo verde Arachis pintoi é o menos eficiente na redução da produção de biomassa seca e germinação das plantas daninhas testadas. 
ANEXOS 


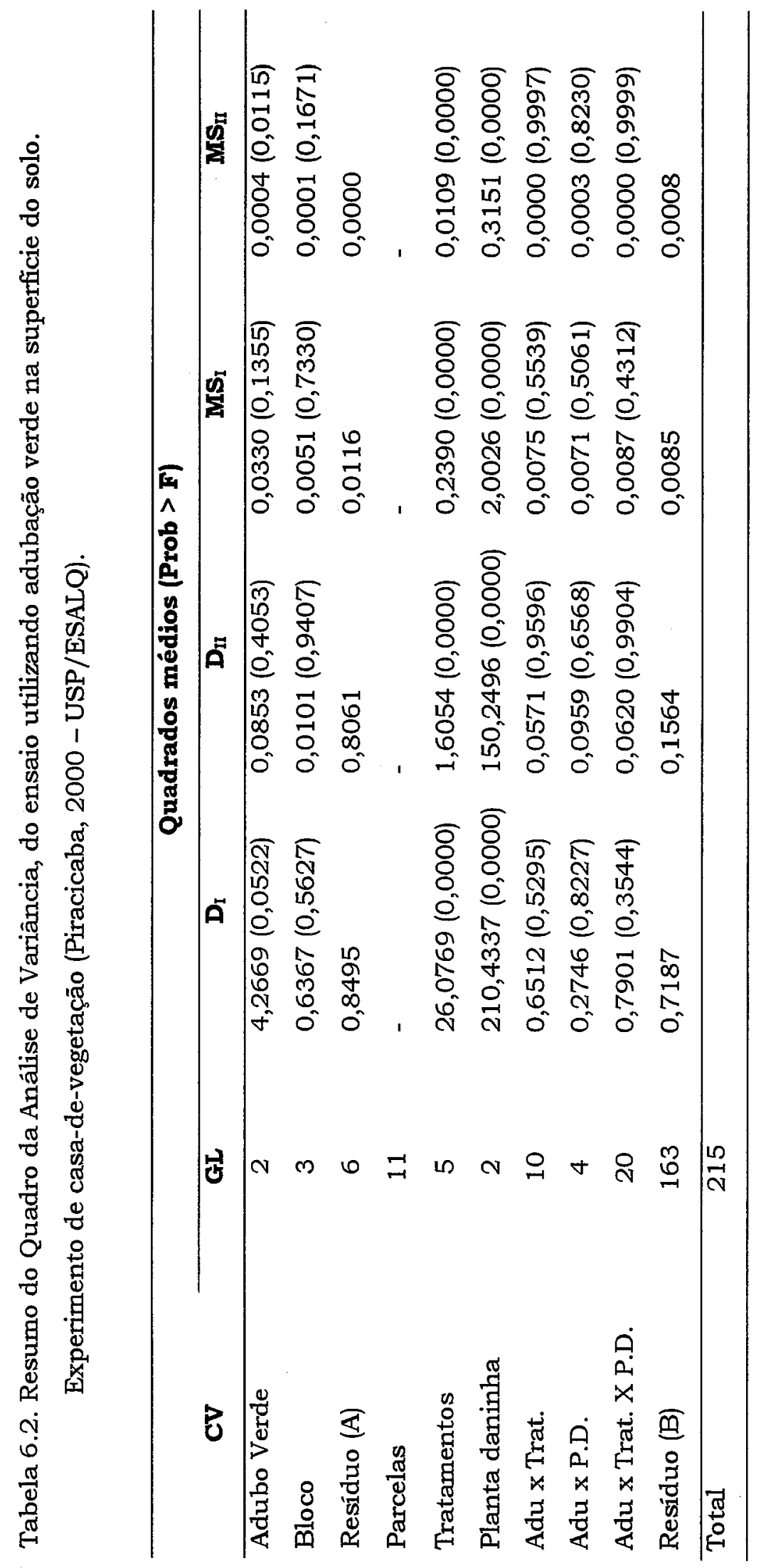




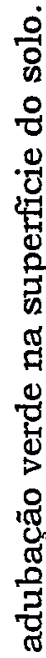

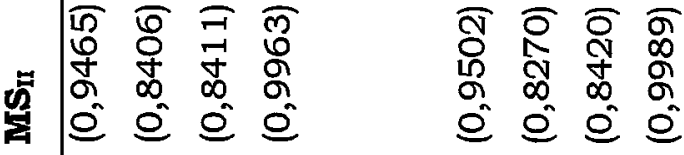

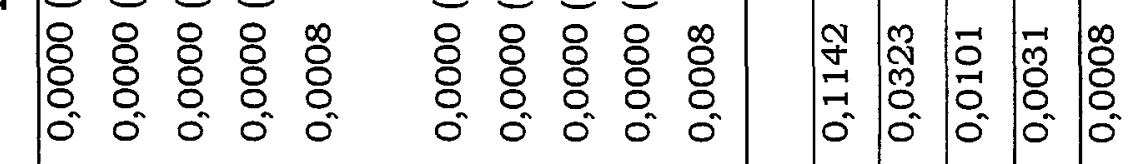

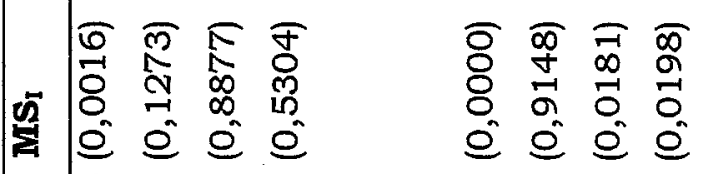

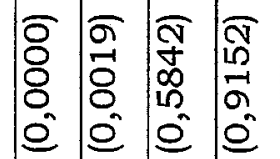

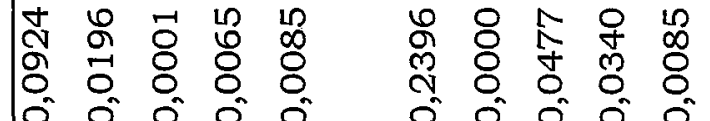

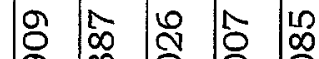

露

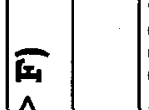

宁

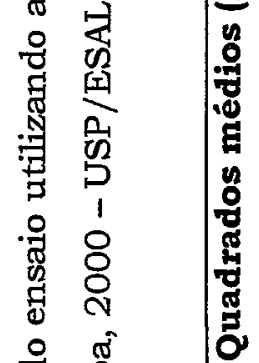

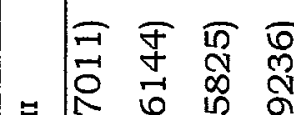

A $\begin{array}{llll}0 & 0 & 0 & 0 \\ 0 & 0 & 0 & 0\end{array}$

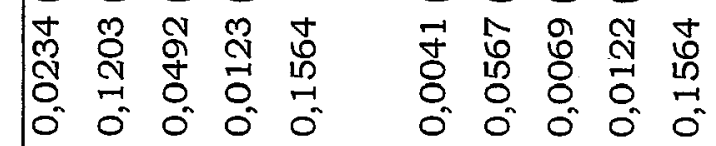

$\frac{\text { : }}{\circ}$

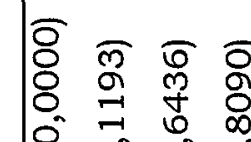

A $\begin{array}{llll}0 & 0 & 0 \\ 0 & 0 & 0 & 0 \\ 0 & 0 & 0\end{array}$

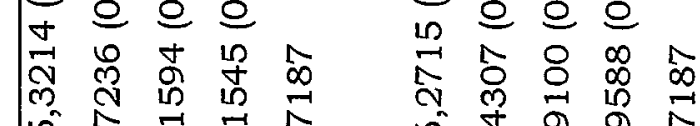

胥

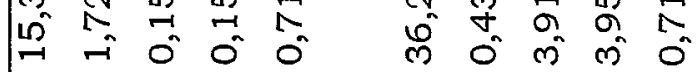

?

귤

己

of

요 웅

"ृ⿰彳

艺

范

कृ

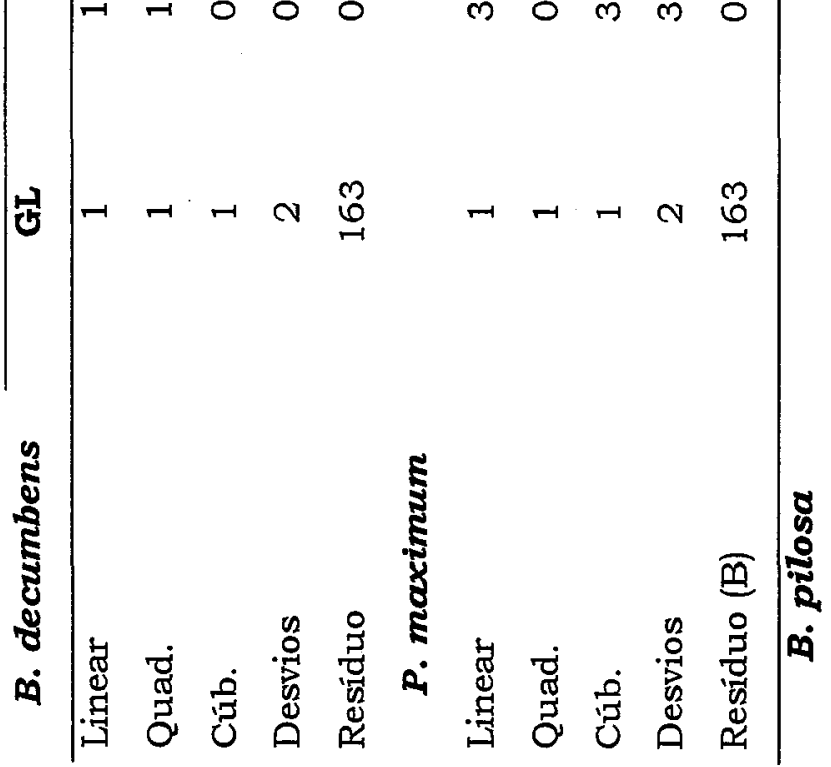

요

○ ल

잉

e $\hat{e}$ e

\begin{tabular}{lllll}
0 & $\infty$ & 0 & 0 & 0 \\
\hdashline & 0 & 0 & 0 & 0 \\
& 0 & 0 & 0
\end{tabular}

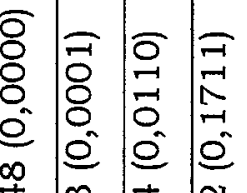

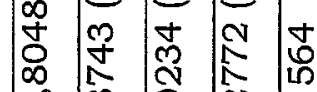

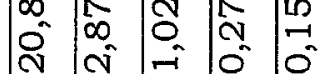

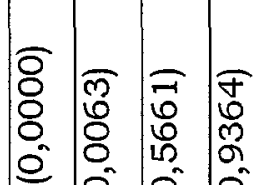

e

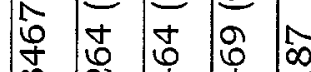

m N

$\begin{array}{llllll}\infty & \infty & 0 & 0 & N \\ \infty & \text { in } & 0 & 0 & 0\end{array}$ 


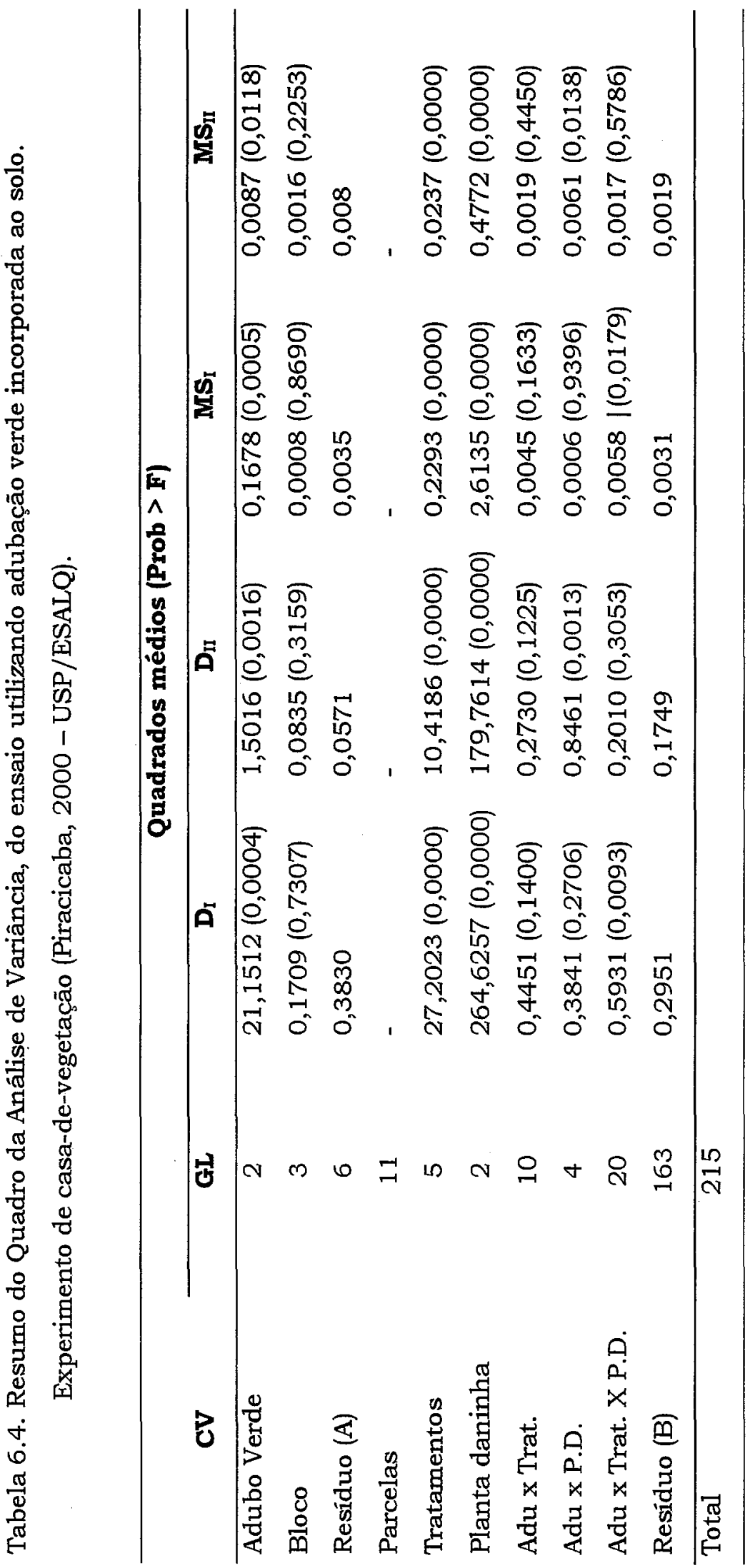




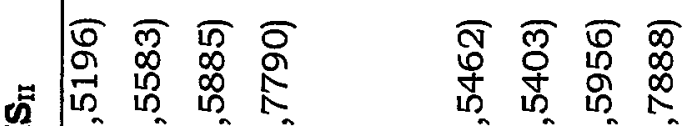

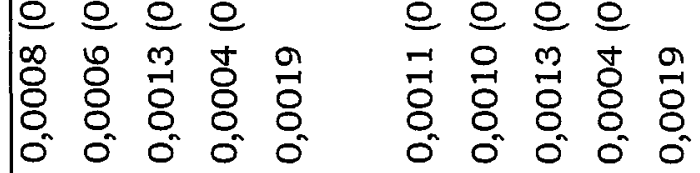

뜽

10

e 0 é

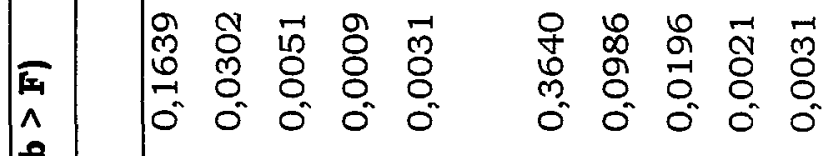

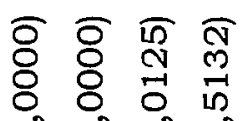

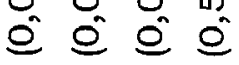

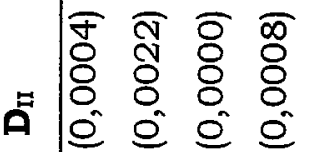

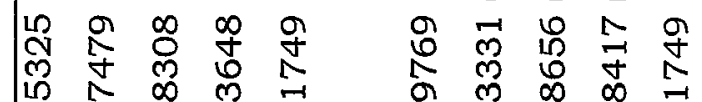

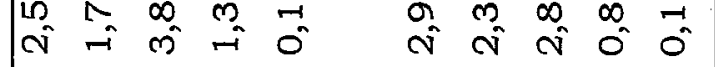

สิ

$\begin{array}{ccc}0 & 0 & 0 \\ 0 & 0 & 0\end{array}$

-

응

点

n

:

을

엄

है

o

ช

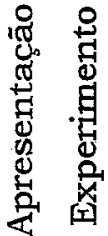

เก

$\frac{0}{\frac{\pi}{d}}$

\section{8}

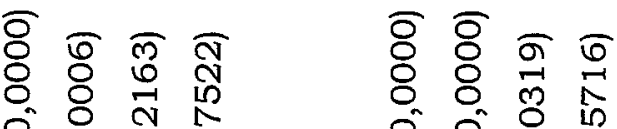

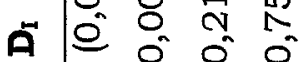

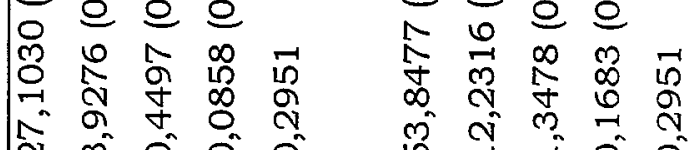

స̂.

0
0
0
0
0
8
8
8
0
0

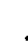

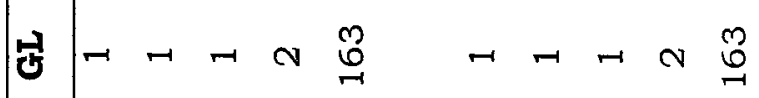

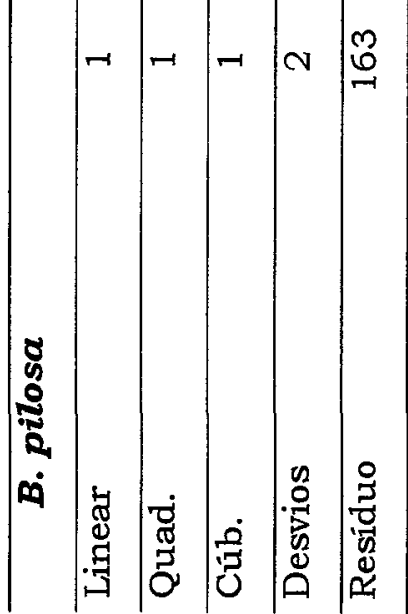




\section{CONCLUSÕES GERAIS}

a) O plantio de leguminosas (Arachis pintoi, Crotalaria juncea e Cajanus cajan) nas entrelinhas da cultura de abacate em formação, reduz, de forma significativa, a infestação e emergência de plantas daninhas.

b) As leguminosas Crotalaria juncea e Cajanus cajan são mais eficientes na redução da infestação das plantas daninhas estudadas do que o Arachis pintoi.

c) A Crotalaria juncea é o adubo verde que, de forma geral, foi menos prejudicado pelas interferências negativas das plantas daninhas testadas, seguida pelo Cajanus cajan e Arachis pintoi.

d) Independentemente da época de plantio, existe, para o Arachis pintoi, a necessidade de um manejo de plantas daninhas no estabelecimento da cultura.

e) O efeito direto da adubação verde na redução do recrutamento do banco de sementes, e conseqüente alteração na dinâmica populacional de plantas daninhas, pode fazer parte do manejo 
integrado de plantas daninhas, além de contribuir com outros benefícios inerentes à utilização desta prática agrícola.

f) A utilização de fitomassa do adubo verde Cajanus cajan é eficiente na redução da emergência das plantas daninhas estudadas, demonstrando grande potencial de uso desta leguminosa, possivelmente pelos seus efeitos alelopáticos.

g) A utilização de diferentes tipos e quantidades de fitomassa das leguminosas estudadas causam efeitos supressivos semelhantes, nas monocotiledôneas Brachiaria decumbens e Panicum maximum, sendo, porém mais pronunciado na dicotiledônea Bidens pilosa.

h) Os herbicidas aplicados em pré-emergência, de maneira geral, causam menor fitotoxicidade ao Arachis pintoi quando comparado com os herbicidas pós-emergentes, sendo o diuron o que apresenta maior seletividade.

i) Os herbicidas fluazifop-p-butil e MSMA aplicados em pósemergência, apresentam seletividade ao Arachis pintoi, em doses normalmente recomendadas para culturas agricolas.

j) Novas pesquisas devem ser desenvolvidas para o estudo da seletividade de outros herbicidas no controle de plantas daninhas e limitação do crescimento na cultura de Arachis pintoi.

k) A utilização de coberturas verdes, como, por exemplo, o Arachis pintoi, tem grande potencial na supressão de plantas daninhas. Entretanto, existe carência de informações precisas sobre características fenológicas, morfológicas e fisiológicas da cultura nos 
agroecossistemas. Assim, as pesquisas básicas devem concentrar esforços nos seguintes itens: a) caracteristicas da arquitetura da planta que determinem a interceptação da radiação (fitomassa, capacidade de cobertura do solo, densidade), b) propriedades alelopáticas, c) fenologia compativel com a cultura principal e com os tratos culturais utilizados, e d) adaptação para as condições do ambiente local. 


\section{REFERÊNCIAS BIBLIOGRÁFICAS}

AGUILlERA, M. M.; MARTINS, S.; MATSUOKA, S. Produtividade da cana-de-açúcar rotacionada com leguminosas em solo infestado com nematóides. In: REUNIÃO BRASILEIRA DE NEMATOLOGIA, 9. Piracicaba, 1985. (Resumos).

ALDRICH, R.J. Allelopathy in weed management. In: WEED-CROP ECOLOGY PRINCIPLES IN WEED MANAGEMENT. Editora Breton Pub, 198411 cap.8, p.87-112. 1984.

AL-KHATIB, K.; LIBBEY, C.; BOYDSTON, R. Weed suppression with Brassica green manure crops in green pea. WEED SCIENCE, v.45, p.439-445, 1997.

ALMEIDA, F. S. Influência da cobertura morta no plantio direto e na biologia do solo. In: SIMPÓSIO SOBRE POTENCIAL AGRÍCOLA DOS CERRADOS, 1, Goiânia, 1985. Goiânia: Fundação Cargill/Empresa Goiana de Pesquisa Agropecuária. 1985. p.109-149. 
ALMEIDA, F. S.; RODRIGUES, B.N. GUIA DE HERBICIDAS: recomendações para uso em plantio direto e convencional. Londrina: IAPAR. 1985. 468p.

ALMEIDA, F. S. A Alelopatia e as plantas. Circular IAPAR n.53, p.60, 1988.

ALMEIDA, F.S. Controle de plantas daninhas em plantio direto. Circular IAPAR n.67. 33 p, 1991.

ANDERSON, W. P. Methods of weed control. In: ANDERSON, W. P. WEED SCIENCE: PRINCIPLES. 2.ed. StPaul: West Publishing Company, 1983. p.65-122.

AURVAlle, A.; GUAZZELli, M. J.; PINHEIRO, S. AGROPECUÁRIA SEM VENENO. 2.ed. Porto Alegre: L\&PM Editores, 128p. 1985.

AYARZA, M. A.; VILELA, L; PIZARRO, E..A. Estratégias de cultivo de milho (Zea mays) sobre cobertura permanente de Arachis pintoi. Planaltina, DF. EMBRAPA-Cerrados. v.20, n.1, p.28-30, 1998.

BALL, D.A.; MILLER, S.D. Weed seed population response to tillage, and herbicide use in three irrigated cropping sequence. WEED SCIENCE, v.38, p.511-517, 1990. 
BARRALIS, G.; CHADOEUF, R. Potential de semencier du terres arables. WEED RESEARCH, v.27, p.417-424, 1987.

BLAIR, W. HERBICIDE RESISTANCE IN WEEDS: na overview. Princeton; New Jersey: American Cyanamid, Agricultural Division, Crop Protection Chemicals Department. 1991. 16p.

BUHLER, D.D. Influence of tillage systems on weed populations dynamics and management in corn and soybean in the central USA. CROP SCIENCE, v.35, p.1247-1258, 1995.

BUHLER, D.D.; HARTZLER, R.G.; FORCELLA, F. Implications of weed seedbank dynamics to weed management. WEED SCIENCE, v.45, p.329-336, 1997.

BULISANI, E. A.; BRAGA, N. R.; ROSTON, A. J. Utilização de leguminosas como cobertura de solo em sistemas de adubação verde ou rotação de culturas. In: ENCONTRO PAULISTA DE PLANTIO DIRETO. Piracicaba: USP/ESALQ, 1987. p.63-70.

CAETANO, R.S. Dinâmica do banco de sementes de plantas daninhas na cultura dos citros (Citrus sinensis C.) submetida a diferentes sistemas de manejo. Tese (Doutorado)-Piracicaba 2000. 105p. Escola Superior de Agricultura "Luiz de Queiroz", Universidade de São Paulo. 
CARDINA, J.; SPARROW, D.A. Comparison of methods to predict weed seedling populations from the soil seedbank. WEED SCIENCE, v.44, p.46-51, 1996.

CARVALHO BRASIL, E. Sistema de cultivo em faixas como alternativa ao sistema tradicional de agricultura: primeiras experiências no nordeste paraense. Belém. PA. n.67, p.9-26, 1992.

CARVALHO, M.M.; NAKAGAWA, J. SEMENTES: ciência, tecnologia, produção. Campinas: Fundação Cargill, 1983. 429p.

CAVERS, P.B.; BENOIT, D.L. Seed banks in arable land. In: LECK, M.A.; PARKER, V.T.; SIMPSON, R.L. ECOLOGY OF SOIL SEED BANKS. London: Academic Press, 1989. p. 309-328.

CHADOEUF-HANNEL, $R$. La dormance chez les semences des mauvaises herbs. AGRONOMIE, v.5, p.761-772, 1985.

CHANCELLOR, R. J. Dormancy in weed seeds. OUTLOOK ON AGRICULTURE. v.11, n.2, p.87-93, 1982.

CHANCELLOR, R. J. Dormancy. In: CONFERENCE OF SEED AND ENVIRONMENT. Halvern, 1979. Proceedings. 1980. p.86-105p. 
CHRISTOFFOLETI, P. J. Controle de Brachiaria decumbens Stapf e de Cyperus rotundus L. em área de cana-de-açúcar (Saccharum $\mathrm{spp}$ ) através da técnica de rotação com amendoim (Arachis hypogaea L.) integrada ao uso de herbicidas. Piracicaba, 1988. 117p. Tese (Mestrado)- Escola Superior de Agricultura "Luiz de Queiroz", Universidade de São Paulo.

CLEMENT, C.R.; DeFRANK, J. The use of ground covers during the establishment of heart-of-palm plantations in Hawaii. HORTSCIENCE. v.33, n.5, p.814-815, 1998.

CLEMENTS, D.R.; BENOIT, D.L.; MURPHY, S.D. et al. Tillage effects on weed seed return and seedbank composition. WEED SCIENCE, v.44, p.314-322, 1996.

COLEMAN, R. G. Perennial peanuts - potential looms larger in citrus. CITRUS INDUSTRY. p.43-44, 1995.

CÔME, D. Germination In: MAZLIAK, P. CROISANCE ET DÉVELOPPEMENT. Physiologie Vegetale II. Paris: Hermann, 1982. p.129-225.

CURL, E. A. Control of plant by crop rotation. THE BOTANICAL REVIEW. v.29, n.4, p.413-479, 1963. 
DEHAAN, R. L., WYSE, D. L., EHLKE, N. J. et al. Simulation of springseeded smother plants for weed control in corn. WEED SCIENCE. v.42, p.35-43, 1994.

DERPSCH, R., CALEGARI, A. Guia para adubação verde de inverno. DOCUMENTOS IAPAR, n.9. Londrina. 96 p. 1993.

DESSAINT, F.; CHADOEUF, R.; BARRALIS, G. Etude de la dynamique communauté adventice: III. Influence à long terme dês techniques culturales sur la composition spécifique du stock semencier. WEED RESEARCH, v.30, p.319-30, 1990.

DONADIO, L. C. ABACATE PARA EXPORTAÇÃO: aspectos técnicos da produção. 2 ed. (revisão aumentada). Brasília: EMBRAPA. 1995. $53 p$.

DOWLER, C. C.; HAUSER, E. W.; JOHNSON, A. W. Crop-herbicide sequences on a Southeastern Coastal Plain Soil. WEED SCIENCE, v.22, n.5, p.500-505, 1974.

EBERLEIN, C.V.; SHEAFFER, C.C.; OLIVEIRA, V.F. Corn growth and yield in an alfafa living mulch system. PRODUTOS AGRÍCOLAS JORNAL. v.5, p.332-339, 1992.

ECHTENKAMP, G. W.; MOOMAW, R. S. No-till corn production in a living mulch system. WEED TECHNOLGY. v.3, p.262-266, 1989. 
ELKINS, D., FREDERKING, D., MARASHI, R. et al. Living mulch for notillage corn and soybeans. JOURNAL OF SOIL AND WATER CONSERVATION. v.38, p.431-433, 1983.

ENACHE, A. J.; ILNICKI, R. D. Weed control by subterranean clover used as living mulch. WEED TECHNOLOGY. v.4, p.534-538, 1990.

FACELLI, J.M. and PICKETT, S.T.A. Plant litter: its dynamics and effects on plant community structure. BOTANY REVIEWS. v.57, p.1-32, 1991.

FERNANDES, M. F.; BARRETO, A.C.; EMIDIO FILHO, J. Fitomassa de adubos verdes e controle de plantas daninhas em diferentes densidades populacionais de leguminosas. Aracaju. SE. EMBRAPA. v.34:, n.9, p.1593-1600, 1999.

FERNÁNDEZ-QUINTANILLA, C. Studying the population dynamics of weeds. WEED RESEARCH, v.25 p.443-47, 1988.

FERNÁNDEZ-QUINTANILLA, C.; SAAVEDRA, M.S.; GARCIA TORRES, L. Ecologia de las malas hierbas. In: GARCIA TORRES, L. FERNÁNDEZ-QUINTANILLA，C. FUNDAMENTOS SOBRE MALAS HIERBAS Y HERBICIDAS. Madrid: Mundi-Prensa, 1991. cap.2, p.4969. 
FRANÇA, V.; MOREIRA, T. AGRICULTOR ECOLÓGICO: técnicas alternativas de produção. São Paulo: Nobel. 1988. 75p.

FRANCO, A.A.; SOUTO, S. M. CONTRIBUIÇÃO DA FIXAÇÃO BIOLÓGICA DE N2 NA ADUBAÇÃO VERDE: Adubaçāo Verde no Brasil. Campinas: Fundação Cargill, 1984. p.199-215.

FREITAS, J. A. D.; COELHO, M. A.; FERREYRA, H. F. F. Efeitos de corretivos químicos e materiais orgânicos no movimento da água $\mathrm{e}$ estrutura do solo salino-sódico. REVISTA BRASILEIRA DE CIÊNCIA DO SOLO, v.8, p.261-4, 1984.

GELMINI, G. A. HERBICIDAS: indicações básicas para a cultura do milho. Campinas:CATI, 1995. 36p. (Manual 54).

HARTWIG, N.L. Cropping practices using crownvetch in conservation tillage. In: POWER, J.F. THE ROLE OF LEGUMES IN CONSERVATION TILLAGE SYSTEMS. Ankeny, Iowa: Soil Conservation Society Americam. 1987. p.109-110.

HARTWIG, N. L. Influence of a crownvetch living mulch on dandelion invasion in corn. Proceeding Northeast. WEED SCIENCE SOCIETY. v.33, p.25-28, 1989.

IGUE, K. DINÂMICA DA MATÉRIA ORGÂNICA E SEUS EFEITOS NAS PROPRIEDADES DO SOLO: Adubação verde no Brasil. Campinas: Fundação Cargill. p.232-67, 1984. 
KISS, J. Cobertura Viva. REVISTA GLOBO RURAL. São Paulo: Globo, 1997. p.9-11.

KOHL, D. H.; SHEARER, G. B.; COMMONER, B. Fertilizer nitrogen contribution to nitrate in surface water, in a cornbelt watershed. SCIENCE, v.174, p.1331-4, 1971.

LEIGHTY, C. E. Crop rotation. In: U.S. Department Agriculture Yearbook of Agriculture Soils and Men. p.406-430, 1938.

MARZOCCA, A. MANUAL DE MALEZAS. Atualizada e ampliada por: O. J. MARSICO E. O. DEL PUERTO. 3.ed. Buenos Aires: Editora Hemisfério Sur, 1976. 576p.

MAXWELL, B. D.; ROUSH, M. L. e RADOSEVICH, S. R. Predicting the evolution and dynamics of herbicide resistance in weed populations. WEED TECHNOLOGY, v.4, p.2-13, 1990.

MELETTI, L. M. M. PROPAGAÇÃO DEFRUTÍFERAS TROPICAIS. Ed. Guaíba Agropecuária. 2000. 239p.

MELLO, F. A. F.; BRASIL SOBRINHO, M. O. C. Efeitos da incorporação de resíduos de mucuna preta, Crotalaria juncea L. e feijão baiano: influência sobre a produção de arroz. REVISTA DE AGRICULTURA. v.35, n.1, p.33-40, 1960 . 
MIYASAKA, S. Histórico do estudo de adubação verde, leguminosas viáveis e suas características. ADUBAÇÃO VERDE NO BRASIL. Campinas: Fundação Cargill, p.64-123, 1984.

MOHLER, C. L. Effects of tillage and mulch on weed biomass and sweet corn yield. WEED TECHNOLOGY. v.5, p.545-552, 1991.

MOLISH, H. DER EINFLUSS EINER PFLANZE AUF DIE ANDEREALLELOPATHIE. Jena: Gustav Fisher. 1937. 106p.

NEME, N. A.; MIRANDA, H. S.; FOSTER, R. A ação da cultura de feijãode-porco no combate a tiririca. In: CONGRESSO PANAMERICANO DE AGRONOMIA. 2. Piracicaba, 1954. p.261-262.

NETO, F. S. Controle de plantas daninhas através de coberturas verdes consorciadas com milho. EMBRAPA. v.28, n.10, p.1165-1171, 1993.

NICHOLSON, A. G., WIEN, H. C. Screening of turfgrasses and clovers for use as living mulches in sweet corn and cabbage. JOURNAL OF AMERICAN SOCIETY HORTICULTURE SCIENCE. v.108, p.10711076, 1983.

PASCHOAL, A. D. PRODUÇÃO ORGÂNICA DE ALIMENTOS: agricultura sustentável para os séculos XX e XXI. Piracicaba: PCLQ/USP, 1994. $191 p$. 
PIAMONTE, R. P. SEMINÁRIO SOBRE NOVAS TENDÊNCIAS DE MANEJO DO SOLO: húmus e microorganismos. São Paulo: Instituto de Cooperativismo e Associativismo. CATI/SAA, 1996. 63p.

PIZARRO, E.A.; RAMOS, A.K.B.; CARVALHO, M.A. Produccion y persistencia de siete acceiones de Arachis pintoi asocidadas con Paspalum maritimum en el cerrado brasileño. PASTURAS TROPICALES. v.19, n.2, p.4044, 1997.

POPEY, A. I. Factores involved in dormancy and germination of Capsella Bursa-pastoris (L.) Medik. And Senecio vulgaris L. E. AFRIC AGRICULTURAL FORESTRY JOURNAL. v.41, p.304, 1976.

PRIMAVESI, A.M. Solo/Adubação verde. REVISTA GUIA RURAL ABRIL. p.38-44. 1986.

PUTNAM, A. R.; DUKE, W.D. Biological suppression of weeds: evidence of allelophaty in accessions of cucumber. SCIENCE, v.185, p.3702.1974.

PUTNAM, A.R. Weed allelopathy. In: DUKE, S.O. WEED PHYSIOLOGY. v.II: Reproduction and Ecophysiology. Boca Raton: CRC Press, 1985 cap.5, p.131-155.

RICE, E.L. Allelopathy. 2.ed. London: Academic Press, 1983. 422p. 
RICE, K.J. Impacts of seed banks on grassland community structure and population dynamics. In: LECK, M.A.; PARKER, V.T.; SIMPSON, R.L. (Ed). ECOLOGY OF SOIL SEED BANKS. London: Academic Press, 1989. p.69-86.

ROBERTS, H.A. Seed banks in the soil. ADVANCES IN APPLIED BIOLOGY, v.6, p.1-55, 1981.

SCHREIBER, M.M. Influence of tillage, crop rotation, and weed management on giant foxtail (Setaria faberi) population dynamics and corn yield. WEED SCIENCE, v.40, p.645-653,1992.

SIMPSON, R.L.; LECK, M.A.; PARKER, V.T. Seed banks: General concepts and methodological issues. In: LECK, M.A.; PARKER, V.T.; SIMPSON, R.L. (Ed). ECOLOGY OF SOIL SEED BANKS. London: Academic Press, 1989. p.3-8.

SINGH, Y.; KHIND, C. S.; SINGH, B. Efficient management of leguminous green manures in wetland rice. ADVANCES IN AGRONOMY, v.45, p.137-87, 1991.

SUPPO, F. R. EL AGUACATE. México: AGT Editor, 1982. 167p.

SWAIN, T. Secondary compounds as protective agents. ANNUAL REVIEW OF PLANT PHYSIOLOGY. p.479-501, 1977. 
TEASDALE, J. R.; DAUGHTRY C. S. T. Weed suppression by live and desiccated hairy vetch. WEED SCIENCE. v.41, p.207-212, 1993.

TEASDALE, J.R. Cover crops, smother plants, and weed management. Arbor Press, 1998. p.247-270.

TEMPLETON, A.R.; LEVIN, D.A. Evolutionary consequences of seed pools. AMERICAN NATURALIST, v.114, p.232-249, 1979.

VIEIRA, M. J. Propriedades físicas do solo. N: IAPAR. Plantio direto no estado do Paraná. Londrina. IAPAR. p.19-32, 1981 (IAPAR, CIRCULAR 23).

VINCENT, E. M.; ROBERTS, E. H. The interaction of light, nitrate and alternating temperature in promoting the germination of dormant seeds of common weed species. SEED SCIENCE \& TECHNOLOGY. v.5, p.659-670, 1977.

VOGTMANN, H.; WAGNER, R. AGRICULTURA ECOLÓGICA - TEORIA \& PRÁTICA. Porto Alegre: Mercado Aberto. 1987. 168p.

WALKER, R. H.; BUCHANAN, G. A. Crop manipulation in integrated weed management systems. WEED SCIENCE. v.30 (suppl. 1). p.1724, 1982 . 
WHITE, J.G.; SCOTT, T. W. Effects of perennial forage-legume living mulches on no-till winter wheat and rye. FIELD CROPS RESEARCH. v.28, p.135-148, 1991.

WILKINSON, S.R.; DEVINE, O.J.; BELESKY, J.W. et al. No-tillage intercropped corn production in tall fescue sod as affected by sod control and nitrogen fertilization. AGRONOMY JOURNAL. v.79, p.685-690, 1987.

WUTKE, E. B.; BULISANI, E. A.; MASCARENHAS, H. A. A. Adubação verde: manejo da fitomassa e espécies utilizadas no Estado de São Paulo. In: I CURSO SOBRE ADUBAÇĀO VERDE. Campinas: IAC, 1993. resumos, 1993 (DOCUMENTOS IAC 35). p.17-30.

ZIMDAHL, R. L. WEED-CROP COMPETITION: a review. Corvallis, International Plant Protection Center: Oregon State University. 1980. $197 p$.

ZIMDAHL, R. L. Allelopathy. In: FUNDAMENTALS OF WEED SCIENCE. San Diego: Academic Press Inc. cap.7 San Diego. cap.7, p.135- 146. 1993. 